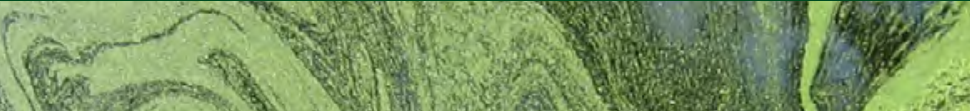

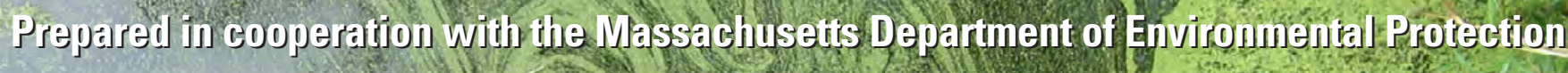

and

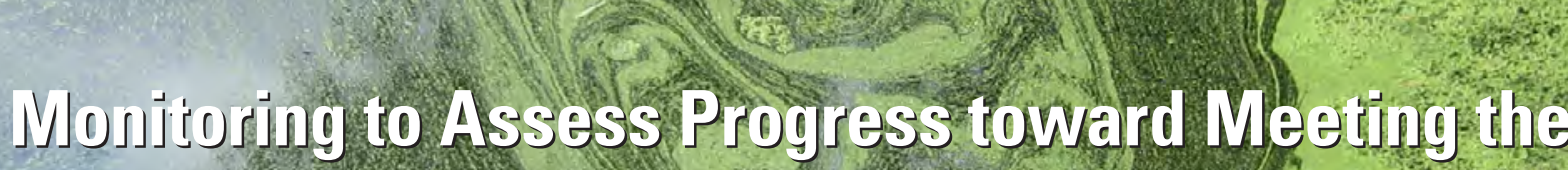

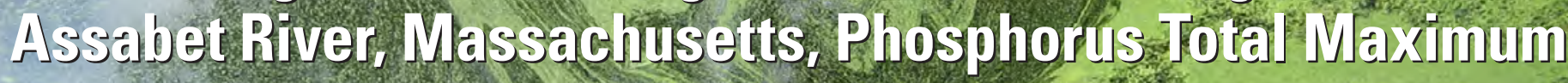
DajJy Load - Aquatic lyacr ophy te Biomess ajud SedjuentPliosphorus Fluy

Scientific lnvestigations Report $2011=5179$

U.S. Departusent of the luferior U.S. Geologitoal stincy 


\section{Waiting for Lesser Duckweed: On a Proposal of Issa's}

inter

December, a weekday,

no one else crossing

(by way of the wet path)

the bird sanctuary's yellow: spongy bottomlaind ${ }^{2}$ s. no duckweed

any longer willow-green-

for now, the almost smoldering

gas-lacy water says,

it's down making turions:

The way to be introduced to it

is first

to meet nothing. In rain a thin microscope-specimen rain.

One raises a face

to flooded sketchlike

territories of trees,

sepia, seeping;

to blunt, upward bluffs of ivy,

bared poison oak;

a soaking places:

fed by springs and floods; shallow water table. strained by willows.

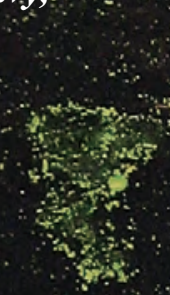

In spring, in a more forwàrd month, yellow-red willow-bud hisks

will sharpen the trail,

their old pen tips,

oleo-spot gulls? beáks, brighten the flat brown pond.

and a man with a knife, whack, whack,

righthanded down the path,

will kill new twigs too new

yet to be woody.

But there's

no duckweed until the summer

when finally where a creek

swims in,

there's duckweed

barely tugging

the moss-strandy bottom,

wheatcolored

seed-shrimps

touring in and around the barbless roots, hyaline drag-lines, where a mud-smooth leech adjusts

and tows

the duckweed a bit.

Some places it bunches,

simple but chained, a soft hauberk on the siteam.

Some places it wrinkles,

a basilisk's back.

It is utterly simple

and multiple.

It is floating, one of mainy rafts.

The water here is cold,

fresh, still and hard. Ovals, ovals.

Shet's take the duckiveed way

to clouds:

said Issa. Lets tale eit

when it comed to us

its leaf not called a leaif,

diaineter for which there is no term
but green:
let's follow
the least weed up

to sumbuses

however hainy

steps if takes

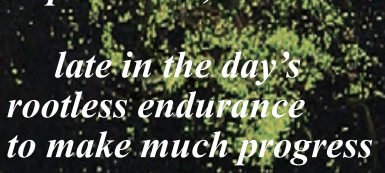

" the drickweed togis

Let us grow and wane with this ideal the way

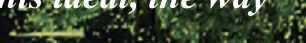

it keeps the single petal of its bloom confidential in a hollow on its side. 


\section{Monitoring to Assess Progress toward Meeting the Assabet River, Massachusetts, Phosphorus Total Maximum Daily Load-Aquatic Macrophyte Biomass and Sediment-Phosphorus Flux}

By Marc J. Zimmerman, ${ }^{1}$ Yu Qian, ${ }^{2}$ and Tian Yong $0 .{ }^{3}$

Prepared in cooperation with the

Massachusetts Department of Environmental Protection

Scientific Investigations Report 2011-5179

U.S. Department of the Interior

U.S. Geological Survey

${ }^{1}$ U.S. Geological Survey, Massachusetts-Rhode Island Water Science Center, Northborough, Massachusetts.

${ }^{2}$ University of Massachusetts, Amherst, Massachusetts.

${ }^{3}$ Central Michigan University, Mt. Pleasant, Michigan. 


\section{U.S. Department of the Interior \\ KEN SALAZAR, Secretary \\ U.S. Geological Survey \\ Marcia K. McNutt, Director}

U.S. Geological Survey, Reston, Virginia: 2011

For more information on the USGS - the Federal source for science about the Earth, its natural and living resources, natural hazards, and the environment, visit http://www.usgs.gov or call 1-888-ASK-USGS.

For an overview of USGS information products, including maps, imagery, and publications, visit http://www.usgs.gov/ pubprod

To order this and other USGS information products, visit http://store.usgs.gov

Any use of trade, product, or firm names is for descriptive purposes only and does not imply endorsement by the U.S. Government.

Although this report is in the public domain, permission must be secured from the individual copyright owners to reproduce any copyrighted materials contained within this report.

Suggested citation:

Zimmerman, M.J., Yu Qian, and Tian Yong 0., 2011, Monitoring to assess progress toward meeting the Assabet River, Massachusetts, phosphorus total maximum daily load—Aquatic macrophyte biomass and sedimentphosphorus flux: U.S. Geological Survey Scientific Investigations Report 2011-5179, 77 p. (Also available at http://pubs.usgs.gov/sir/2011/5179/.) 


\section{Acknowledgments}

Many of our colleagues at the Massachusetts Department of Environmental Protection/Division of Watershed Management provided enthusiastic support, assistance, and valuable advice for this study; they include Dennis R. Dunn, the late Arthur Screpetis, Brian Friedmann, Alice Rojko, Kimberly Groff, and Richard Chase. Suzanne Flint, Staff Scientist of the Organization for the Assabet River, provided us with full access to the organization's large historical database and collaborated extensively in the studies of biomass and distribution. Roger and Jeanne Gay of Maynard, Massachusetts, Christopher and Maureen Gay of Hudson, Mass., and Stephen Angelini of Stow, Mass., provided access to their backyards and boat docks in support of field work. Mark Henry (Michigan Department of Environmental Quality) helped in the selection of equipment for use in the sediment-phosphorus flux chamber. Christopher Pratt, project manager of the Veolia Water North America, (Westborough, Mass.) wastewater-treatment plant, allowed us access to the river on the plant site for the collection of water samples.

The project further benefited greatly from the assistance of U. S. Geological Survey (USGS) coop, summer, and volunteer students Larissa Cupp (Northeastern University), Lisa Lach (Wesleyan University), and Nicole Rich (Salem State College), respectively. USGS hydrologist Gene W. Parker routinely monitored (duckweed) distribution in the impoundments. USGS colleague reviewers Stewart Rounds and Nancy Simon provided extensive comments on the draft report that led to notable improvements to the text. Other USGS colleagues-Marcus C. Waldron, Gerald G. Girouard, Andrew J. Massey, Kimberly W. Campo, Jason R. Sorenson, and James M. Duncan - made substantial contributions to the wide variety of logistics that were required to successfully complete the field studies. 
THIS PAGE INTENTIONALLY LEFT BLANK 


\section{Contents}

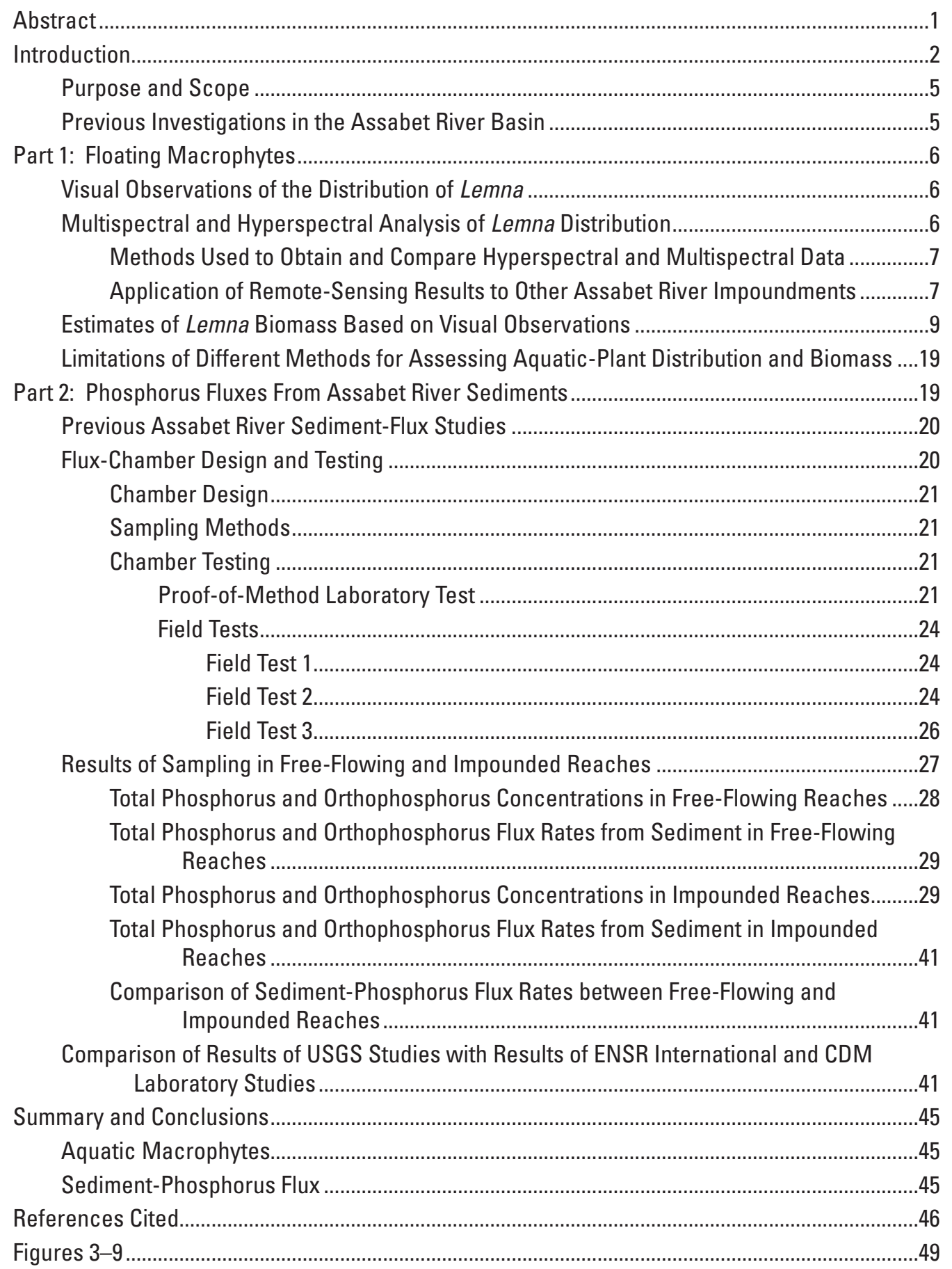




\section{Figures}

1. Map showing locations of study-area dams, sampling sites, and wastewater-treatment plant discharge points in the Assabet River Basin in central Massachusetts...

2. Photograph showing aquatic macrophytes in 2006 near the Ben Smith Dam .....

3. Orthophotomaps showing grid structure used for identifying Lemna distribution in Assabet River impoundments: $A$, Allen Street impoundment; $B$, Hudson impoundment; $C$, Gleasondale impoundment; $D$, Ben Smith impoundment; and E, Powdermill impoundment

4. Representative photographs showing differences in Lemna coverage on comparable dates (August 27, 2007, and August 28, 2008) at sites where Lemna visual observations were made during this study: $A$, Allen Street impoundment; $B$, Hudson impoundment; $C$, a cove in the Hudson impoundment; $D$, Gleasondale impoundment; $E$, Ben Smith impoundment near the dam; $F$, Ben Smith impoundment downstream from the White Pond Road bridge; $G$, Ben Smith impoundment upstream from the White Pond Road bridge; and $H$, Powdermill impoundment

5. Maps showing percent coverages of Lemna in the Allen Street impoundment based on visual observations on comparable dates in 2007 and 2008

6. Maps showing percent coverages of Lemna in the Hudson impoundment near Park Street and the Route 85 dam based on visual observations on comparable dates in 2007 and 2008.

7. Maps showing percent coverages of Lemna in the Gleasondale impoundment based on visual observations on comparable dates in 2007 and 2008.

8. Maps showing percent coverages of Lemna in the Ben Smith impoundment upstream and downstream from White Pond Road and near the dam based on visual observations on comparable dates in 2007 and 2008.

9. Maps showing percent coverages of Lemna in the Powdermill impoundment based on visual observations on comparable dates in 2007 and 2008.

10. Maps showing analyses of estimated aquatic-plant distributions in the Ben Smith impoundment on August 16, 2007 based on $A$, IKONOS imagery; $B$, visual field-survey observations; $C$, remote-sensing results classified according to the visual-survey coverage categories; and $D$, discrepancies between remote-sensing and visual surveys for each coverage category

11. Graphs showing range of Lemna biomass estimates for the Allen Street impoundment in 2007 and 2008 based on the Massachusetts Department of Environmental Protection areal-coverage categories.

12. Graphs showing range of Lemna biomass estimates for the Hudson impoundment near Park Street in 2007 and 2008 based on the Massachusetts Department of Environmental Protection areal-coverage categories.

13. Graphs showing range of Lemna biomass estimates for the Hudson impoundment near the Route 85 dam in 2007 and 2008 based on the Massachusetts Department of Environmental Protection areal-coverage categories .

14. Graphs showing range of Lemna biomass estimates for the Gleasondale impoundment in 2007 and 2008 based on the Massachusetts Department of Environmental Protection areal-coverage categories.

15. Graphs showing range of Lemna biomass estimates for the Ben Smith impoundment upstream from the White Pond Road bridge in 2007 and 2008 based on the Massachusetts Department of Environmental Protection areal-coverage categories 
16. Graphs showing range of Lemna biomass estimates for the Ben Smith impoundment downstream from the White Pond Road bridge in 2007 and 2008 based on the Massachusetts Department of Environmental Protection areal-coverage categories

17. Graphs showing range of Lemna biomass estimates for the Ben Smith impoundment near the dam in 2007 and 2008 based on the Massachusetts Department of Environmental Protection areal-coverage categories

18. Graphs showing range of Lemna biomass estimates for the Powdermill impoundment in 2007 and 2008 based on the Massachusetts Department of Environmental Protection areal-coverage categories.

19. Photograph showing U.S. Geological Survey personnel preparing to deploy the sediment-phosphorus flux chamber.

20. Photograph showing internal components of the sediment-phosphorus flux chamber....

21. Graph showing changes in specific conductance and dissolved oxygen concentrations during laboratory testing of the sediment-phosphorus flux chamber

22. Photograph showing U.S. Geological Survey personnel deploying the sediment-phosphorus flux chamber for the first field test.

23. Graph showing changes in dissolved oxygen concentration and oxidation-reduction potential during the first field test of the sediment-phosphorus flux chamber

24. Graph showing changes in dissolved oxygen concentration and oxidation-reduction potential during the second field test of the sediment-phosphorus flux chamber

25. Graph showing changes in dissolved oxygen concentration and oxidation-reduction potential during the third field test of the sediment-phosphorus flux chamber.

26. Graphs showing phosphorus and dissolved oxygen concentrations measured in the first round of sediment-phosphorus flux sampling in five free-flowing reaches in the Assabet River study area in 2007: $A$, Westborough wastewater-discharge point; $B$, School Street and $C$, Robin Hill Road in Northborough; $D$, Cox Street in Hudson; and $\mathrm{E}$ and $F$, Elks Club in Maynard.

27. Graphs showing phosphorus and dissolved oxygen concentrations measured in the second round of sediment-phosphorus flux sampling in two free-flowing reaches in the Assabet River study area in 2007: $A$, Westborough wastewaterdischarge point; and $B$, School Street, Northborough ..

28. Graphs showing phosphorus and dissolved oxygen concentrations measured in the third round of sediment-phosphorus flux sampling in two free-flowing reaches in the Assabet River study area in 2008: $A$, Westborough wastewater-discharge point; and $B$, School Street, Northborough

29. Graphs showing phosphorus and dissolved oxygen concentrations measured in the first round of sediment-phosphorus flux sampling in six impounded reaches in the Assabet River study area in 2007: $A$, Hudson site 17; $B$, Hudson site 20; $C$, Hudson site 29; D, Ben Smith site 32; E, Ben Smith site 38; and $F$, Ben Smith site 41

30. Graphs showing phosphorus and dissolved oxygen concentrations measured in the second round of sediment-phosphorus flux sampling in four impounded reaches in the Assabet River study area in 2007: $A$, Hudson site 20; $B$, Hudson site 29; $C$, Ben Smith site 32; and $D$, Ben Smith site 41 
31. Graphs showing phosphorus and dissolved oxygen concentrations measured in the third round of sediment-phosphorus flux sampling in four impounded reaches in the Assabet River study area in 2008: $A$, Hudson site 20; $B$, Hudson site 29;

$C$, Ben Smith site 32; and D, Ben Smith site 41

\section{Tables}

1. Comparison between visual observations and satellite imagery of percentages of Lemna coverage of surficial grids in the Allen Street, Hudson, and Gleasondale impoundments, August 16, 2007

2. Comparison between visual observations and satellite imagery of percentages of Lemna coverage of surficial grids in the Allen Street, Hudson, Gleasondale, and Ben Smith impoundments, August 16, 2007.

3. Biomass (dry weight) per unit area of Lemna samples collected in 2007 ........................10

4. Rates of change in concentrations of total phosphorus and orthophosphorus sampled inside flux chambers in free-flowing reaches in the study area... .35

5. Rates of change in concentrations of total phosphorus and orthophosphorus sampled inside flux chambers in impounded reaches in the study area.

6. Comparisons among flux rates of sediment phosphorus in laboratory studies reported by ENSR International and Camp Dresser \& McKee, Inc., and determined in field studies by the U.S. Geological Survey 
Conversion Factors, Datum, and Abbreviations

\begin{tabular}{|c|c|c|}
\hline Multiply & By & To obtain \\
\hline \multicolumn{3}{|c|}{ Length } \\
\hline inch (in) & 2.54 & centimeter $(\mathrm{cm})$ \\
\hline inch (in) & 25.4 & millimeter $(\mathrm{mm})$ \\
\hline foot $(\mathrm{ft})$ & 0.3048 & meter $(\mathrm{m})$ \\
\hline mile (mi) & 1.609 & kilometer $(\mathrm{km})$ \\
\hline yard (yd) & 0.9144 & meter $(\mathrm{m})$ \\
\hline \multicolumn{3}{|c|}{ Area } \\
\hline acre & 4,047 & square meter $\left(\mathrm{m}^{2}\right)$ \\
\hline acre & 0.4047 & hectare (ha) \\
\hline acre & 0.4047 & square hectometer $\left(\mathrm{hm}^{2}\right)$ \\
\hline acre & 0.004047 & square kilometer $\left(\mathrm{km}^{2}\right)$ \\
\hline square foot $\left(\mathrm{ft}^{2}\right)$ & 929.0 & square centimeter $\left(\mathrm{cm}^{2}\right)$ \\
\hline square foot $\left(\mathrm{ft}^{2}\right)$ & 0.09290 & square meter $\left(\mathrm{m}^{2}\right)$ \\
\hline square inch $\left(\mathrm{in}^{2}\right)$ & 6.452 & square centimeter $\left(\mathrm{cm}^{2}\right)$ \\
\hline square mile $\left(\mathrm{mi}^{2}\right)$ & 2.590 & square kilometer $\left(\mathrm{km}^{2}\right)$ \\
\hline \multicolumn{3}{|c|}{ Volume } \\
\hline gallon (gal) & 0.003785 & cubic meter $\left(\mathrm{m}^{3}\right)$ \\
\hline gallon (gal) & 3.785 & liter (L) \\
\hline million gallons (Mgal) & 3,785 & cubic meter $\left(\mathrm{m}^{3}\right)$ \\
\hline ounce, fluid (fl oz.) & 29.57 & milliliter $(\mathrm{mL})$ \\
\hline \multicolumn{3}{|c|}{ Flow rate } \\
\hline acre-foot per day (acre-ft/d) & 0.01427 & cubic meter per second $\left(\mathrm{m}^{3} / \mathrm{s}\right)$ \\
\hline foot per second (ft/s) & 0.3048 & meter per second $(\mathrm{m} / \mathrm{s})$ \\
\hline foot per day (ft/d) & 0.3048 & meter per day (m/d) \\
\hline cubic foot per second $\left(\mathrm{ft}^{3} / \mathrm{s}\right)$ & 0.02832 & cubic meter per second $\left(\mathrm{m}^{3} / \mathrm{s}\right)$ \\
\hline \multicolumn{3}{|c|}{ Mass } \\
\hline ounce, avoirdupois (oz) & 28.35 & gram $(\mathrm{g})$ \\
\hline pound, avoirdupois (lb) & 0.4536 & kilogram (kg) \\
\hline $\begin{array}{l}\text { pound per day per square foot } \\
{\left[(\mathrm{lb} / \mathrm{d}) \mathrm{ft}^{2}\right]}\end{array}$ & $4,887,000$ & $\begin{array}{l}\text { milligram per day per square meter } \\
{\left[(\mathrm{mg} / \mathrm{d}) \mathrm{m}^{2}\right]}\end{array}$ \\
\hline
\end{tabular}

Temperature in degrees Celsius $\left({ }^{\circ} \mathrm{C}\right)$ may be converted to degrees Fahrenheit $\left({ }^{\circ} \mathrm{F}\right)$ as follows:

$$
{ }^{\circ} \mathrm{F}=\left(1.8 \times{ }^{\circ} \mathrm{C}\right)+32
$$

Temperature in degrees Fahrenheit $\left({ }^{\circ} \mathrm{F}\right)$ may be converted to degrees Celsius $\left({ }^{\circ} \mathrm{C}\right)$ as follows:

$$
{ }^{\circ} \mathrm{C}=\left({ }^{\circ} \mathrm{F}-32\right) / 1.8
$$

Vertical coordinate information is referenced to the North American Vertical Datum of 1988 (NAVD 88).

Horizontal coordinate information is referenced to the North American Datum of 1983 (NAD 83).

Specific conductance is given in microsiemens per centimeter at 25 degrees Celsius $(\mu \mathrm{S} / \mathrm{cm}$ at $\left.25^{\circ} \mathrm{C}\right)$.

Concentrations of chemical constituents in water are given either in milligrams per liter (mg/L) or micrograms per liter $(\mu \mathrm{g} / \mathrm{L})$.

Oxidation-reduction potential is given in millivolts. 


\section{Abbreviations}

$\begin{array}{ll}\text { CDM } & \text { Camp Dresser \& McKee, Inc. } \\ \text { DO } & \text { dissolved oxygen } \\ \text { MassDEP } & \text { Massachusetts Department of Environmental Protection } \\ \text { NDVI } & \text { Normalized Difference Vegetative Index } \\ \text { ORP } & \text { oxidation-reduction potential } \\ \text { OrthoP } & \text { orthophosphorus } \\ \text { P } & \text { phosphorus } \\ \text { RPD } & \text { relative percent difference } \\ \text { SOD } & \text { sediment oxygen demand } \\ \text { TMDL } & \text { total maximum daily load } \\ \text { TP } & \text { total phosphorus } \\ \text { USACE } & \text { U.S. Army Corps of Engineers } \\ \text { USEPA } & \text { U.S. Environmental Protection Agency } \\ \text { USGS } & \text { U.S. Geological Survey }\end{array}$




\title{
Monitoring to Assess Progress toward Meeting the Assabet River, Massachusetts, Phosphorus Total Maximum Daily Load-Aquatic Macrophyte Biomass and Sediment-Phosphorus Flux
}

\author{
By Marc J. Zimmerman, Yu Qian, and Tian Yong 0.
}

\section{Abstract}

In 2004, the Total Maximum Daily Load (TMDL) for Total Phosphorus in the Assabet River, Massachusetts, was approved by the U.S. Environmental Protection Agency. The goal of the TMDL was to decrease the concentrations of the nutrient phosphorus to mitigate some of the instream ecological effects of eutrophication on the river; these effects were, for the most part, direct consequences of the excessive growth of aquatic macrophytes. The primary instrument effecting lower concentrations of phosphorus was to be strict control of phosphorus releases from four major wastewatertreatment plants in Westborough, Marlborough, Hudson, and Maynard, Massachusetts. The improvements to be achieved from implementing this control were lower concentrations of total and dissolved phosphorus in the river, a 50-percent reduction in aquatic-plant biomass, a 30-percent reduction in episodes of dissolved oxygen supersaturation, no low-flow dissolved oxygen concentrations less than 5.0 milligrams per liter, and a 90-percent reduction in sediment releases of phosphorus to the overlying water.

In 2007, the U.S. Geological Survey, in cooperation with the Massachusetts Department of Environmental Protection, initiated studies to evaluate conditions in the Assabet River prior to the upgrading of wastewater-treatment plants to remove more phosphorus from their effluents. The studies, completed in 2008, implemented a visual monitoring plan to evaluate the extent and biomass of the floating macrophyte Lemna minor (commonly known as lesser duckweed) in five impoundments and evaluated the potential for phosphorus flux from sediments in impounded and free-flowing reaches of the river.

Hydrologically, the two study years 2007 and 2008 were quite different. In 2007, summer streamflows, although low, were higher than average, and in 2008, the flows were generally higher than in 2007. Visually, the effects of these streamflow differences on the distribution of Lemna were obvious. In 2007, large amounts of floating macrophytes accumulated behind bridge constrictions and dams; in 2008, high flows during the early part of the growing season carried floating macrophytes past bridges and over dams, minimizing accumulations. Samples of Lemna were collected and weighed to provide an estimate of Lemna biomass based on areal coverage during the summer growing seasons at eight sites in the five impoundments. Average estimated biomass during 2007 was approximately twice the 2008 biomass in each of the areas monitored. In 2007, in situ hyperspectral and high-resolution, multispectral data from the IKONOS satellite were obtained to evaluate the feasibility of using remote sensing to monitor the extent of aquatic plant growth in Assabet River impoundments. Three vegetation indices based on light reflectance were used to develop metrics with which the hyperspectral and satellite data were compared. The results of the comparisons confirmed that the high-resolution satellite imagery could differentiate among the common aquatic-plant associations found in the impoundments. The use of satellite imagery could counterbalance emphasis on the subjective judgment of a human observer, and airborne hyperspectral data can provide higher resolution imagery than multispectral satellite data.

In 2007 and 2008, the potential for sediment flux of phosphorus was examined in free-flowing reaches of the river and in the two largest impoundments-Hudson and Ben Smith. These studies were undertaken to determine in situ flux rates prior to the implementation of the Assabet River Total Maximum Daily Load (TMDL) for phosphorus and to compare these rates with those used in the development and evaluation of the TMDL. Water samples collected from a chamber placed on the river bottom were analyzed for total phosphorus and orthophosphorus. Ambient dissolved oxygen concentrations and seasonal temperature differences appeared to affect the rates of sequestration and sediment release of phosphorus. When dissolved oxygen concentrations remained relatively high in the chambers and when the temperature was relatively low, the tendency was for phosphorus concentrations to decrease in the chambers, indicating sediment sequestration of phosphorus; when dissolved oxygen concentrations dropped to near zero and temperatures were warmest, phosphorus concentrations increased in the chambers, indicating phosphorus 
flux from the sediment. The rates of release and sequestration in the in situ studies were generally comparable with the rates determined in laboratory studies of Assabet River sediment cores for State and Federal agencies. Sediment-core and chamber studies produced substantial sediment fluxes to the water column only under extremely low-DO or anaerobic conditions rarely found in the Assabet River impoundments; thus, sediment is not likely to be a major phosphorus source, especially when compared to the wastewater effluent, which sustains higher ambient concentrations. The regulatory agencies now (2011) have substantial laboratory and field data with which to determine the required 90-percent reduction in phosphorus flux after the completion of upgrades to the wastewater-treatment plants that discharge to the Assabet River.

\section{Introduction}

The Assabet River Basin is a rapidly developing area of Massachusetts where water and wastewater demands strain water resources. The 53-kilometer $(\mathrm{km})$-long river, draining a basin approximately 460 kilometers $\left(\mathrm{km}^{2}\right)$ in area, passes through nine towns before reaching its confluence with the Sudbury River in Concord to form the Concord River (fig. 1). Along the way, nine dams affect the river's flow and morphology. The main stem of the river from Westborough to Maynard, Massachusetts, including five of its impoundments formed by old mill dams (Allen Street in Northborough, Hudson in Hudson, Gleasondale in Stow, Ben Smith in Maynard, and Powdermill in Acton), constitute the study area discussed here.

In spite of its diversity of wildlife, popularity for recreational activities, and designation, in part, as a Wild and Scenic River, the Assabet is a highly eutrophic system largely because of nutrient enrichment from wastewatertreatment-plant effluent that may dominate up to 90 percent of the streamflow during low-flow periods (Massachusetts Department of Environmental Protection, 2004). In accordance with Massachusetts water-quality standards, the Assabet is designated a Class B water body, defined as a water body capable of supporting aquatic wildlife habitat and primary- and secondary-contact recreation; however, the Assabet has been categorized as an impaired water body since these classifications were first applied in 1996. Excessive nutrients, organic enrichment, and low dissolved oxygen concentrations have been cited as the primary causes of this classification. The extent of eutrophication is most clearly evident in the impounded reaches, where algal mats and rooted and floating macrophytes proliferate under low-flow, high-nutrient-concentration conditions during the growing season (fig. 2). The dams that impound these reaches once served to power the sawmills, gristmills, and other industrial operations that constituted the economic bases for the towns along the river. In the early twentieth century, wool-scouring, tannery, and shoe-factory waste, along with inadequately treated sewage, contributed to contamination of the Assabet (McAdow, 1990). Although those industries are long gone, pressure from new demands for regional development and growth continues to threaten the river's water quality.

Although industrial wastes are no longer directly discharged to the river without treatment, the Assabet nevertheless carries a substantial waste load. This waste load comprises the effluents from the four major wastewatertreatment plants in Westborough, Marlborough, Hudson, and Maynard, Mass. (fig. 1).

In 2005, the final documentation that served as the basis for the Assabet River Phosphorus Total Maximum Daily Load (TMDL) was published (ENSR International, 2005). A TMDL defines the maximum loads of a particular waterquality constituent that a water body may receive without violating State-defined water-quality standards or designated uses. The report described the eutrophic condition of the river resulting from the excessive amounts of nutrients that led to the river's inclusion, as an impaired water body requiring water-quality improvements, on the Integrated List of Waters (formerly known as the 303(d) list of impaired waters) by the Massachusetts Department of Environmental Protection (MassDEP). The listed impairments, in addition to the eutrophic state of the river, included aesthetic impairment and clogging of river reaches with nuisance growths of macrophytes. Phosphorus was designated as the nutrient of concern and was the focus of the required TMDL plan for the Assabet River.

To determine means of controlling phosphorus $(\mathrm{P})$ loads in the Assabet and developing numerical targets that could be monitored, ENSR International calibrated, validated, and applied a Hydrologic-Simulation Program-Fortran (HSPF) model of the basin (ENSR International, 2005). TMDL modeling studies of the Assabet River documented the extent of eutrophication of the river's impoundments and free-flowing reaches and suggested that phosphorus releases from bed sediments may continue to promote excessive plant growth in the river, even following elimination of loads from wastewater-treatment plants and other point sources. Consequently, the report suggested additional measures that might be necessary to attain water-quality standards, including removal of the bed sediments, chemical treatment to immobilize sediment phosphorus, and dam removal or breaching. Selection of the most cost-effective course of action would require more detailed information on the distribution, transport, and internal cycling of phosphorus between sediments and surface water. This information could then be used to judge if annual fluxes of phosphorus from sediment in the river are of sufficient magnitude to require dredging, or if dam removal or breaching could be used to achieve waterquality and other environmental goals.

Based largely on the model simulations, the TMDL plan to regulate nutrients in the river was approved by the U.S. Environmental Protection Agency (USEPA) (Massachusetts Department of Environmental Protection, 2004). Full implementation of the Assabet River Phosphorus TMDL 


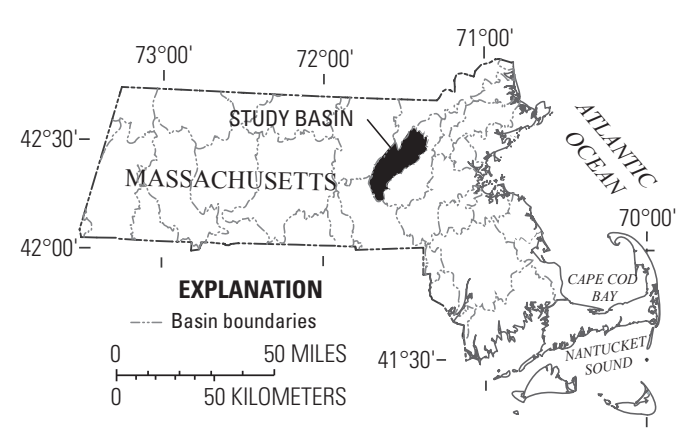

EXPLANATION

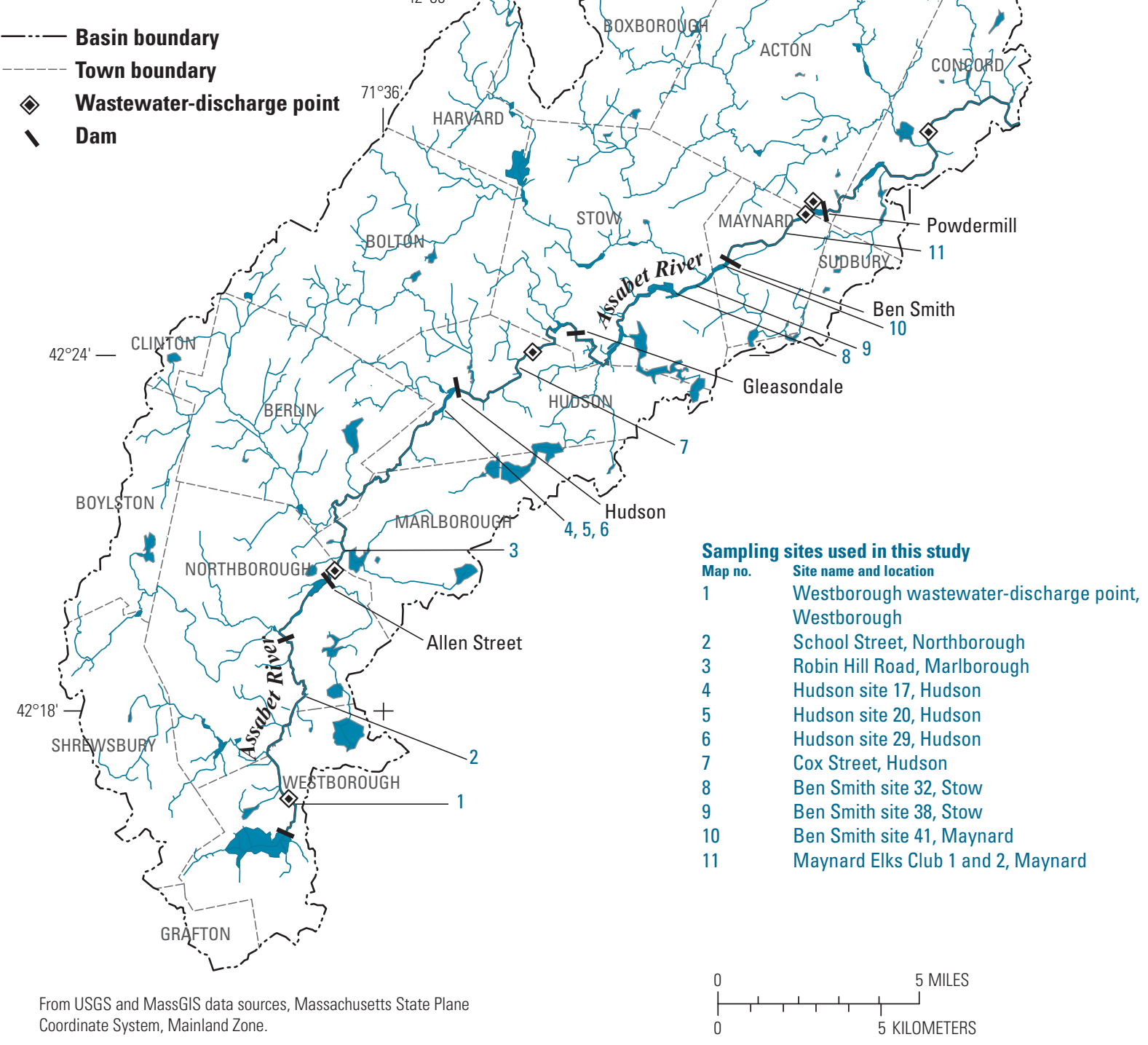

Figure 1. Locations of study-area dams, sampling sites, and wastewater-treatment plant discharge points in the Assabet River Basin in central Massachusetts. 


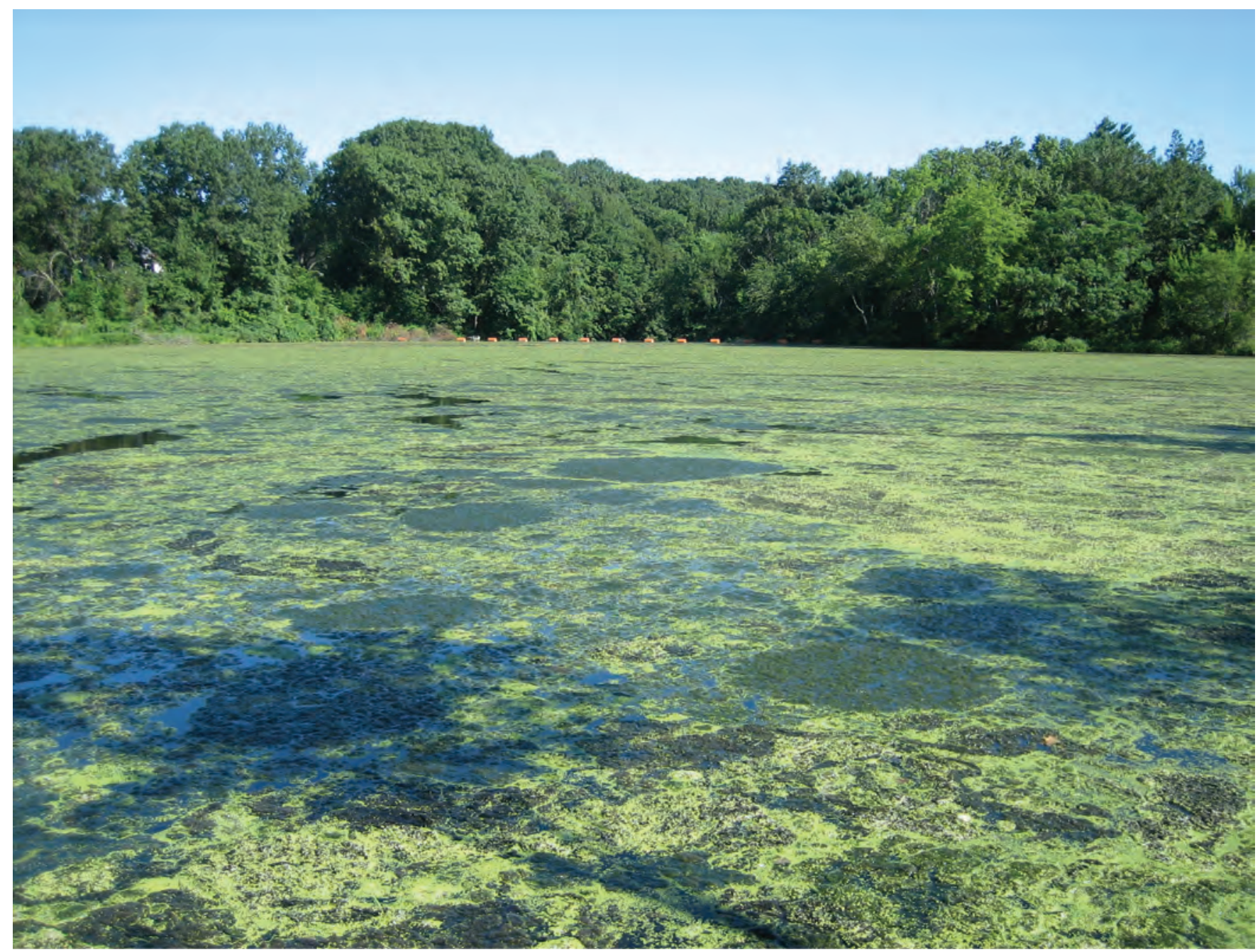

Figure 2. Aquatic macrophytes in 2006 near the Ben Smith Dam (beyond the orange warning barrels). Lemna minor are the palegreen floating plants.

was originally planned for April 2009, but was delayed by upgrades to the wastewater-treatment plants. The TMDL called for the four wastewater-treatment plants to release effluent with total phosphorus (TP) concentrations less than or equal to 0.1 milligram per liter $(\mathrm{mg} / \mathrm{L})$ based on a 60 -day rolling average from April through October and for the monthly average of TP in wastewater discharge to be less than or equal to $1.0 \mathrm{mg} / \mathrm{L}$, and to report only dissolved phosphorus concentrations from November through March. These terms of the TMDL were based on implicit assumptions that, from November through March, all phosphorus discharged from the wastewater-treatment plants would be in the dissolved form and would pass through the impoundments without uptake by organisms or deposition in the sediments. The TMDL also required directly observed or measurable waterquality improvements resulting from the upgrades to the wastewater-treatment plants. These improvements specifically included (1) a 50-percent reduction in the biomass of aquatic plants, (2) a 30-percent reduction in the duration of DO supersaturation above 125 percent, (3) maintenance of lowflow DO concentrations above $5 \mathrm{mg} / \mathrm{L}$, (4) reduced instream concentrations of total and dissolved phosphorus, and (5) a 90 -percent decrease in the rate of phosphorus release from sediments.

Restoration of the Assabet River to the standard designated "fishable and swimmable," commensurate with part of it having been designated as a Wild and Scenic River, is an ambitious goal. The river's highly eutrophic state and its current use in carrying wastewater discharges would make such improvements costly. Assessing the effectiveness of the TMDL after completion of the wastewater-treatment plant upgrades would require knowledge of preexisting 
conditions. To that end, the U.S. Geological Survey (USGS) Massachusetts-Rhode Island Water Science Center, in cooperation with the MassDEP, initiated a monitoring program in 2007-08 to determine (1) the extent and density of the floating macrophyte duckweed (Lemna minor) occurrence in the Assabet River and (2) the status of phosphorus (sediment flux of phosphorus and phosphorus loads) in Assabet River waters and sediments prior to full implementation of the TMDL.

The duckweed studies provide data based on two different approaches that can be used to estimate duckweed extent and biomass. These results support straightforward approaches to evaluating the effects of improvements in wastewater treatment on aquatic plant growth throughout the State and region.

Phosphorus monitoring yields valuable information about the role of sediment flux in the phosphorus budgets of impoundments that are strongly affected by nutrients in wastewater effluents. The results of these phosphorus studies provide baseline information for future assessment of the effectiveness of the wastewater-treatment plant TMDL upgrades in improving water quality in the Assabet. The study's data can be used to verify assumptions used in the modeling studies during the development of the TMDL.

\section{Purpose and Scope}

This report focuses on the Lemna monitoring program developed by the USGS, and subsequently taken over by the MassDEP, and the potential rates of phosphorus release from sediments. The USGS determined the areal extent and biomass of Lemna in eight selected areas of five Assabet impoundments in 2007-08 before wastewater discharges were upgraded to conform to the phosphorus TMDL. The report discusses the two basic approaches used to accomplish this objective: visual observation combined with manual collection of plants, and satellite-based remote sensing. In addition, the report describes a series of in situ experiments to determine the potential sediment-phosphorus flux rates from freeflowing and impounded reaches of the Assabet River. These experiments allowed the comparison of flux rates in the two types of reaches and with rates reported in studies by others. Comparison of these results could support straightforward approaches to evaluating the effects of improvements in wastewater treatment on aquatic plant growth throughout the State and region.

This study was done concurrently with other studies (Camp Dresser \& McKee, Inc., 2007) designed to determine how best to manage nutrient releases from wastewater-treatment plants and from the river's sediments. Nuisance growths of rooted macrophytes with nutrient requirements met by absorption from sediments and from the water column that may contribute to the failure of sections of the river to meet water-quality standards are noted but not evaluated in this report.

\section{Previous Investigations in the Assabet River Basin}

DeSimone (2004) used the MODFLOW program to investigate the effects of water withdrawals and wastewater discharges on the Assabet River's water resources; the report described the loss of aquatic habitat and degradation of water quality resulting from increased water-supply withdrawals from groundwater sources and increased wastewater discharges. Carlson and others (2008) simulated the effects of water demands estimated for the year 2030 under a series of land-use and water-supply conditions; the estimated effects of future development were predicted to cause increases in both main-stem and tributary flows as a result of increased discharges and increased recharge from septic systems, respectively. Parker and others (2004) found that the high proportion of tolerant generalist fish species among the fish communities in the Assabet River Basin indicated a degraded aquatic ecosystem.

Zimmerman and Sorenson (2005) reported the results of sediment sampling in six Assabet impoundments and of their investigation of phosphorus dynamics in the Hudson impoundment. Sediment cores from a predetermined number of randomly selected sites in each impoundment were analyzed for bulk chemical properties, including TP, trace metals, volatile organic compounds, organochlorine pesticides, polycyclic aromatic compounds, polychlorinated biphenyls, and extractable petroleum hydrocarbons. TP concentrations in bulk sediment samples ranged from less than 0.01 (undetectable) to 0.86 percent. The phosphorus-dynamics study did not reveal any net change in the mass of phosphorus in the water column from upstream to downstream in the Hudson impoundment during the summer study period; moreover, no evidence of net sediment-phosphorus release was detected.

Nongovernmental organizations, such as the Organization for the Assabet River (now OARS; http://www.oars3rivers. org) and the Sudbury-Assabet-Concord (SuAsCo) Watershed Community Council (http://www.sudbury-assabet-concord. org), advocate for the protection and enhancement of the Assabet River Basin. OARS has long been involved in routine water-quality monitoring in the basin and, among other activities, produces annual reports documenting its findings (http://www.oars3rivers.org/river/waterquality/reports). The SuAsCo Watershed Community Council serves as an advisory group to the National Park Service on matters related to permits affecting the rivers' resources.

To assess the potential effects of dredging sediment and removing dams in conjunction with upgrades as a means to reduce internal phosphorus loading, the U.S. Army Corps of Engineers (USACE) contracted with Camp Dresser \& McKee (CDM), Inc., to collect data and run model simulations. The evaluations determined that the maximum benefits would be obtained by a combination of wastewatertreatment-plant upgrades and dam removal. Dredging alone was not recommended for reducing phosphorus flux from sediments, but could serve to limit the redistribution of 
phosphorus-containing sediments downstream following dam removal; in the absence of dam removal, dredged sediments would be replenished over time (Camp Dresser \& McKee, Inc., 2007).

\section{Part 1: Floating Macrophytes}

Monitoring Lemna poses some difficult problems. As a small floating macrophyte, its distribution in an impoundment is subject to the effects of wind and current. Breezes cause Lemna to pile up along the shore or even move upstream, and high flows cause Lemna to float over dams and out of impoundments. Moreover, Lemna generally accumulates in shallow, off channel or backwater areas of impoundments, where its roots snag onto rooted aquatic macrophytes, other plants, and fallen tree limbs. These uncontrollable natural factors make it difficult to accurately measure Lemna biomass or the extent to which it may cover the water surface. Because of these difficulties and uncertainties, two approaches were taken to assess Lemna areal extent and distribution in the impoundments.

\section{Visual Observations of the Distribution of Lemna}

The first approach required frequent visual observations to monitor the distribution of Lemna in the five Assabet impoundments. In each impoundment, zones where Lemna tended to accumulate were monitored to estimate the extent and density of Lemna cover. Using GIS coverages, gridded views of the impoundments were created (fig. 3 , in back of report) to serve as printed field maps for recording observations. A USGS observer visited each site twice weekly during the maximum summer growth period (June to September) in 2007. Because streamflows during the early summer growth period were greater in 2008 than in 2007, Lemna did not accumulate to the same extent in 2008 (fig. 4, in back of report), and the monitoring frequency was reduced to one time per week. In general, visits took place in the early morning, when atmospheric conditions usually were calm and had a minimal effect on Lemna distribution.

The observer stood in predetermined locations and entered Lemna-areal-coverage data on the grids. The areal coverages were estimated visually and classified into one of five broad categories prescribed by the MassDEP: not observed ( 0 percent), greater than 0 to 25 percent, greater than 25 to 50 percent, greater than 50 to 75 percent, and greater than 75 to 100 percent. The field data were transferred to spreadsheets and GIS databases after the observer returned to the office.

Above-average flows characterized water years 2007 and 2008; however, early in the 2008 growing season, flows were greater than in 2007. In many of the locations monitored in 2008, the areal extent of Lemna was much less than in 2007 (figs. 5-9, in back of report) because the relatively high flows caused Lemna to float above the algae and rooted macrophytes on which it would typically snag; the high flows also served to carry the free-floating Lemna over the dams before large masses could accumulate.

Although the Lemna coverages were greater in June 2008 than in June 2007 at the Allen Street impoundment (fig. 5, in back of report), the coverages in the summer of 2008 soon decreased, and the coverage throughout the remainder of the summer of 2008 was less than in 2007. The differences in coverage were greatest in July.

In 2007, Lemna accumulated more densely along the edges of the Hudson impoundment than in 2008 (fig. 6, in back of report). Periods of dense Lemna coverage were also longer in 2007 than in 2008. The small oval-shaped embayment (referred to as the Park Street site) had the greatest Lemna coverage in the impoundment for the longest time period in 2007; in 2008, this area was covered with Lemna for only a short period in late summer.

The Gleasondale impoundment has the steepest gradient of the five impoundments studied and tends to have the highest velocity flows. This condition results in the general absence of Lemna accumulations in the main channel in the impoundment (fig. 7, in back of report). During 2007, dense accumulations of Lemna developed along the edges and upstream reaches of the impoundment. Extensive, long-lasting accumulations did not occur in 2008.

The distribution of Lemna was monitored in three sections of the Ben Smith impoundment: upstream and downstream from the White Pond Road bridge (which was replaced in midsummer 2007) and near the dam (fig. 8, in back of report). From late July through mid-September 2007, the three monitored sections of the Ben Smith impoundment were covered extensively with Lemna and other aquatic macrophytes. A storm in mid-September 2007 flushed much of the Lemna over the dam. In 2008, buildups of Lemna were not extensive, tended to occur along the margins of the impoundment, and did not persist.

During 2007 and 2008, construction at the hydroelectric facility at the downstream end of the Powdermill impoundment required a partial drawdown of the impoundment and routing most of the river's flow through a bypass; the effects of the drawdown and rerouting on the distribution of Lemna were not considered as part of this study. Substantial amounts of Lemna were not observed in the open water of the impoundment during either study year (fig. 9, in back of report); on occasion, for example, on June 22, 2007, August 28, 2008, and September 24, 2008, no Lemna were observed at all.

\section{Multispectral and Hyperspectral Analysis of Lemna Distribution}

The second approach for estimating the extent and density of Lemna (and other aquatic macrophytes) coverage with potential application to biomass estimation involved the use of high-resolution, multispectral, satellite-imagery data which 
were compared with hyperspectral, ground-truth data obtained with a spectroradiometer (for a complete description of this work, see Tian and others, 2010). This part of the study was intended to determine the utility of a remote-sensing approach and was not meant to duplicate or supersede the visual-observation approach.

Multispectral (red, green, blue, and near-infrared wavelengths) images from the IKONOS satellite were obtained on dates close to those during which hyperspectral data were collected. The satellite and hyperspectral data were first compared to determine whether the satellite data could be used to monitor the extent of Lemna distribution in the Assabet impoundments. Second, hyperspectral data collected from sites with known areal coverages of Lemna and aquatic-plant associations were compared with the multispectral satellite data to define relations between multispectral and hyperspectral bands; with these data, Lemna coverages and other aquaticplant distributions were determined. Finally, the remote-sensing results were compared with the visual observations.

Hyperspectral data were obtained in situ on August 12 and September 15, 2007. Through a contract with GeoEye, multispectral IKONOS satellite images were obtained that included the study impoundments on the Assabet River. Original plans to obtain complete imagery for three satellite passes over the area during the August through September 2007 period were not realized because GeoEye could not obtain data of adequate quality; however, partial multispectral images that were adequate were obtained on August 15 and 29 and September 14, 2007. Routine visual observations used in the comparisons with the multispectral data were made on August 16, 27, and 30 and September 13 and 17, 2007; that the visualobservation dates did not exactly match the multispectral and hyperspectral data-collection dates did not affect the interpretation of data because the low-flow conditions during these time periods ensured stable distributions of aquatic plants.

\section{Methods Used to Obtain and Compare Hyperspectral and Multispectral Data}

The methods for obtaining and analyzing the hyperspectral and multispectral data were first developed for application to the Ben Smith Impoundment. A spectroradiometer mounted on a boat was used to acquire in situ hyperspectral data (579 measurements) to identify six major reflectance categories common to the impoundments: (1) Lemna (at 100 -percent areal coverage and with three subclasses based on thickness of Lemna accumulation); (2) Wolffia mixed with Lemna (approximately 65-percent Wolffia, the world's smallest known flowering plant); (3) Potamogeton, a macrophyte with floating leaves; (4) a mixture of Lemna and Wolffia with green algal mats, mainly composed of Hydrodictyon and Spirogyra;

(5) Ceratophyllum, a submerged rooted macrophyte; and (6) open water with no aquatic-plant clumps. Three vegetation indices (Normalized Difference Vegetative Index, or NDVI; Near-Infrared Green Angle Index, or NGAI; and Normalized
Water Absorption Depth, or $\mathrm{D}_{\mathrm{H}}$ ) based on the hyperspectral reflectance data were used to quantify coverage and identify plant-species associations (Tian and others, 2010). Multispectral, 4-meter (m)-resolution imagery data from IKONOS were processed and transformed using pan sharpening, a method that improves relatively coarse color-image resolution by cogeoregistering the images with fine resolution black and white images, to yield 1-m-resolution pixels which were first classified into 10 and then into 6 groups similar to those determined from the hyperspectral data (fig. 10A). Ceratophyllum, a submerged macrophyte which is not associated with Lemna, and was not a focus of the monitoring program, was not included in the final evaluations of Lemna distribution.

Next, the satellite data were compared with the results of the visual observations (fig. 10B). These comparisons (fig. 10C), which are based on the NDVI, reveal that there was good agreement between the two methods of identifying aquatic-plant associations in the Ben Smith impoundment. Overall, the agreement between the satellite and visual assessments of Lemna coverage in the Ben Smith impoundment was 79 percent based on classification of the grids used in visual monitoring (Tian and others, 2010; fig. 10D).

\section{Application of Remote-Sensing Results to Other Assabet River Impoundments}

To expand the results of the remote-sensing study, the satellite images of the aquatic macrophyte associations in the Allen Street, Hudson, and Gleasondale impoundments were classified in the same manner as for the aquatic macrophytes in the Ben Smith impoundment. (The Powdermill impoundment was not included because it was outside of the satellite-image boundary.) Then, the NDVI values derived from the satellite imagery for the aquatic macrophytes in the Ben Smith impoundment were used to categorize the aquatic macrophytes in the other three impoundments (as shown in fig. 10A). Finally, the percentage of pixels representing Lemna was determined for each grid, and the grids were categorized by percentage of Lemna coverage into the four classes used in the visual observations.

The differences between the two methods of categorizing Lemna coverages can be represented with a device called a "confusion matrix" (Congalton, 1991) that tabulates how the methods differ (tables 1 and 2). For the Allen Street, Hudson, and Gleasondale impoundments, the grids have been combined into a single matrix (table 1). The values along the highlighted diagonal represent the numbers of grids in each classification for which the methods agree. For example, the third value in the first IKONOS results row, 0-25 percent, indicates that for three of the grids, the visual-observation data fell in the 51-75-percent range. Comparing the number of grids determined by the two methods to have the same percent cover (24) with the total number of grids (43) gives a value of 56-percent agreement (table 1). 

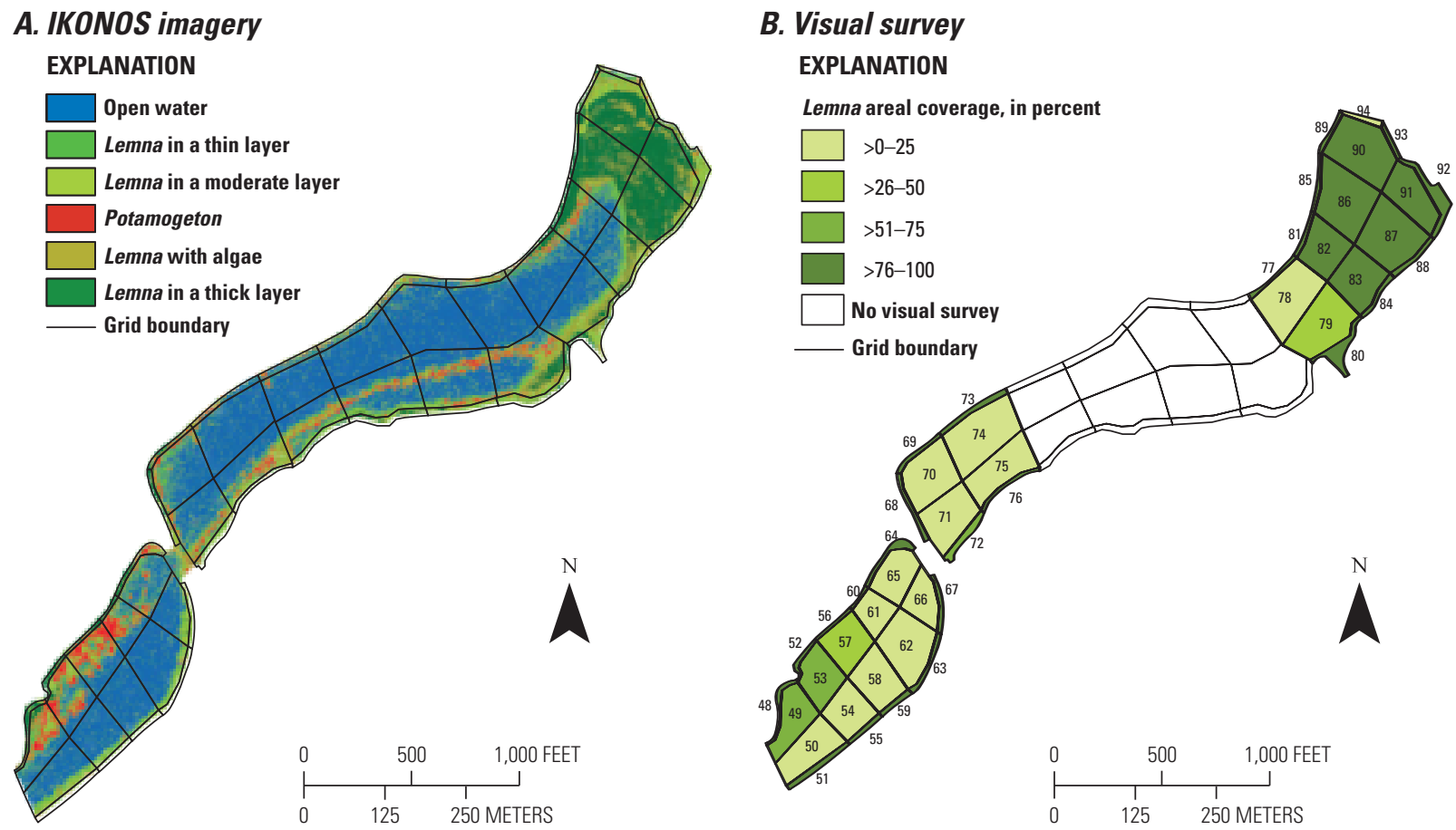

\section{Remote sensing}

\section{EXPLANATION}

Lemna areal coverage, in percent

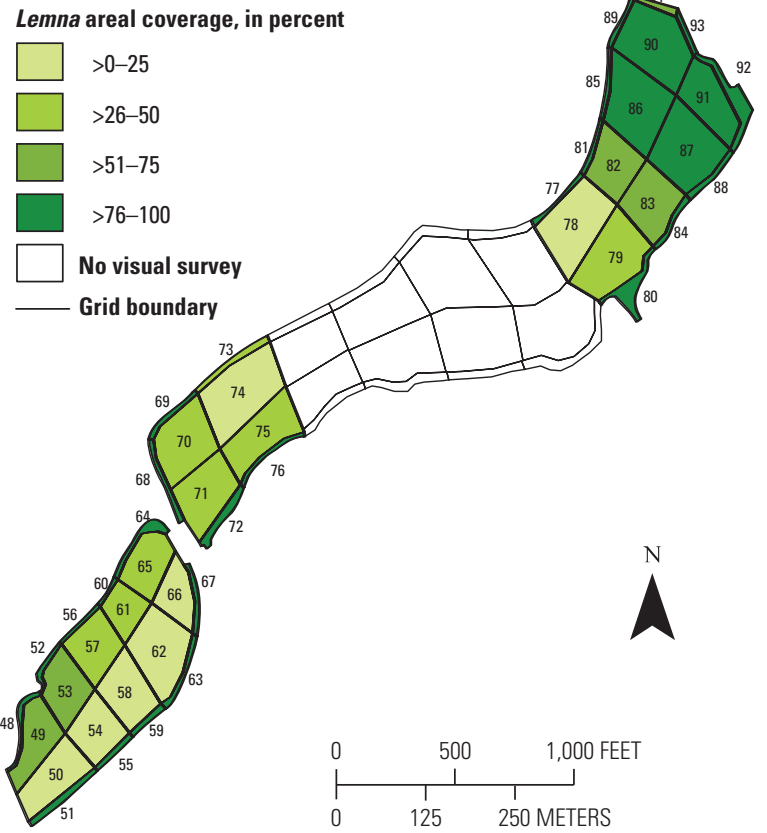

\section{Discrepancies}

\section{EXPLANATION}

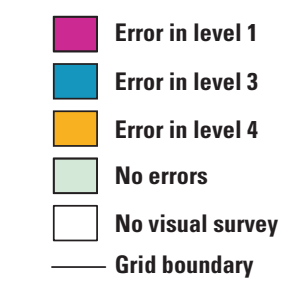

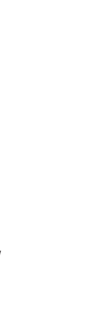

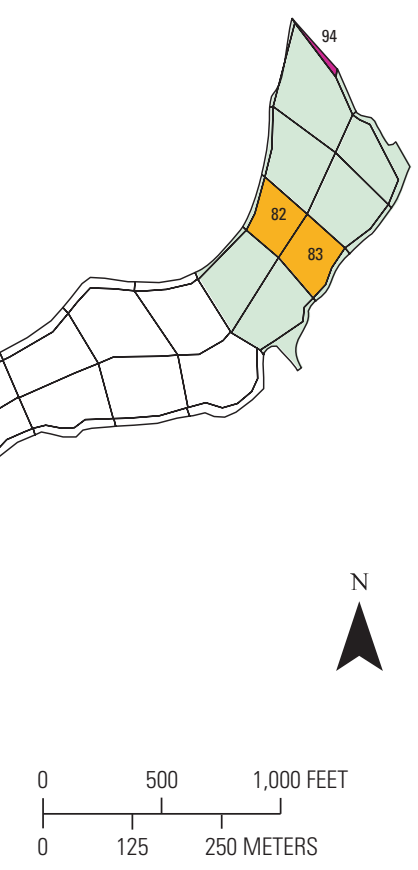

Figure 10. Analyses of estimated aquatic-plant distributions in the Ben Smith impoundment on August 16, 2007 based on $A$, IKONOS imagery; $B$, visual field-survey observations; $C$, remote-sensing results classified according to the visualsurvey coverage categories; and $D$, discrepancies between remote-sensing and visual surveys for each coverage category. Like Lemna, Potamogeton is an aquatic macrophyte with floating leaves. From Tian and others, 2010. Copyright Wiley (2010), used by permission. 
Table 1. Comparison between visual observations and satellite imagery of percentages of Lemna coverage of surficial grids in the Allen Street, Hudson, and Gleasondale impoundments, August 16, 2007.

[Values along the highlighted diagonal represent the numbers of grids in each classification for which the visual-observation and satellite-imagery methods agree]

\begin{tabular}{lccccc}
\hline \multirow{2}{*}{$\begin{array}{c}\text { Ranges of percent cover shown by } \\
\text { IKONOS satellite imagery }\end{array}$} & \multicolumn{4}{c}{ Number of grids observed visually } \\
\cline { 2 - 5 } & $\mathbf{0}$ to $\mathbf{2 5}$ percent & $\mathbf{2 6}$ to $\mathbf{5 0}$ percent & $\mathbf{5 1}$ to $\mathbf{7 5}$ percent & $\mathbf{7 6}$ to $\mathbf{1 0 0}$ percent & Total number of grids \\
\hline 0 to 25 percent & 7 & 7 & 3 & 1 & 18 \\
26 to 50 percent & 0 & 0 & 0 & 1 & 1 \\
51 to 75 percent & 0 & 0 & 0 & 17 & 23 \\
76 to 100 percent & 0 & 0 & 6 & 20 \\
\hline Total number of grids & 7 & 7 & 9 & 43 \\
\hline
\end{tabular}

To determine the overall agreement of the two methods, the corresponding values from the original Ben Smith confusion matrix (Tian and others, 2010) were added to the values for the three upstream impoundments to create a new confusion matrix for all four impoundments (table 2). The resulting rate of agreement was 68 percent.

\section{Estimates of Lemna Biomass Based on Visual Observations}

The Gleasondale impoundment was selected for the collection of Lemna to determine biomass on July 31, 2007 because conditions on that date were favorable for the easy collection of a substantial number of samples from a small area. Lemna were collected from locations with 100-percent Lemna coverage by a hula hoop that encompassed an area of $0.495 \mathrm{~m}^{2}$ and kept Lemna from drifting away during collection. The floating hula-hoop enclosure was first placed on a patch of water completely covered with Lemna; second, the Lemna in the enclosure were harvested and separated from entangled algae. Two people collected a total of twenty samples by this method. The samples were taken to the USGS Water Science Center in Northborough, Mass., where they were drained, weighed, and then dried in an oven at $105^{\circ} \mathrm{C}$ until their weights were constant, indicating complete dryness.

The average Lemna biomass per unit area was calculated to be $29.5 \mathrm{~g} / \mathrm{m}^{2}$, with a standard deviation of 15.8 (table 3). This average biomass per unit area was multiplied by the area of each impoundment grid and then by the maximum and minimum percentage for each density range $(0$, greater than 0-25 percent, greater than 25-50 percent, greater than 50-75 percent, and greater than 75-100 percent) on each monitoring date. The resulting values gave an estimated biomass range and the standard deviation for a given grid on each date. Accounting for the sampling error through application of the standard deviation may add as much as 50-percent uncertainty to the results. The sums of the grids' biomasses yielded the total biomass for each of the eight specific impoundment areas (figs. 11-18) studied during the growing seasons. ${ }^{1}$ Examining

${ }^{1}$ Because the eight areas monitored for Lemna varied in surface area, comparisons of biomass among the areas could be misleading; that is, a small area covered completely with Lemna could have less biomass than another, larger area with 1 to 25 percent cover.

Table 2. Comparison between visual observations and satellite imagery of percentages of Lemna coverage of surficial grids in the Allen Street, Hudson, Gleasondale, and Ben Smith impoundments, August 16, 2007.

[Values along the highlighted diagonal represent the numbers of grids in each classification for which the visual-observation and satellite-imagery methods agree]

\begin{tabular}{lccccc}
\hline \multirow{2}{*}{$\begin{array}{c}\text { Ranges of percent cover shown by } \\
\text { IKONOS satellite imagery }\end{array}$} & \multicolumn{4}{c}{ Number of grids observed visually } \\
\cline { 2 - 5 } & $\mathbf{0}$ to $\mathbf{2 5}$ percent & $\mathbf{2 6}$ to $\mathbf{5 0}$ percent & $\mathbf{5 1}$ to $\mathbf{7 5}$ percent & $\mathbf{7 6}$ to 100 percent & Total number of grids \\
\hline 0 to 25 percent & 14 & 7 & 3 & 1 & 25 \\
26 to 50 percent & 5 & 2 & 0 & 3 & 9 \\
51 to 75 percent & 1 & 0 & 2 & 43 & 50 \\
76 to 100 percent & 0 & 0 & 7 & 49 \\
\hline
\end{tabular}


Table 3. Biomass (dry weight) per unit area of Lemna samples collected in 2007.

\begin{tabular}{cc}
\hline Sample number & Grams per square meter \\
\hline 1 & 18.0 \\
2 & 25.3 \\
3 & 36.0 \\
4 & 56.4 \\
5 & 22.0 \\
6 & 29.9 \\
7 & 23.2 \\
8 & 15.4 \\
9 & 24.0 \\
10 & 17.8 \\
11 & 12.1 \\
12 & 60.4 \\
13 & 40.2 \\
14 & 66.9 \\
15 & 29.9 \\
16 & 28.9 \\
17 & 11.1 \\
18 & 14.7 \\
19 & 32.3 \\
20 & 25.9 \\
Average & 29.5 \\
Median & 25.6 \\
Standard deviation & 15.8 \\
\hline
\end{tabular}

the Lemna distribution maps (figs. 5-9, in back of report) provides an indication of which part of each biomass graph best represents the actual conditions on a given observation date. The graphs of biomass further support the overall visual observation that Lemna coverage was generally greater in 2007 than in 2008 (figs. 5-9, in back of report).

In the Allen Street impoundment, the average calculated Lemna biomass ${ }^{2}$ was approximately $135 \mathrm{~kg}$ at the start of the 2007 growing season, declined to about $75 \mathrm{~kg}$ by midsummer, and declined further during the remainder of the summer (fig. 11). In 2008, the average biomass started at about $100 \mathrm{~kg}$ and declined to about $40 \mathrm{~kg}$ in July. With 0 to 25 percent Lemna cover over substantial areas of the impoundment during both years (fig. 5, in back of report), the biomass values were probably close to the low ends of their ranges for most of the two summers.

At the Park Street site of the Hudson impoundment in 2007 and 2008, initial average biomasses were about $20 \mathrm{~kg}$

\footnotetext{
${ }^{2}$ The term "average biomass" used here refers to the midpoint of the biomass range at a particular point in time in each figure.
}

(fig. 12). In 2007, the average biomass increased to about $75 \mathrm{~kg}$ in July and eventually to about $90 \mathrm{~kg}$ at the end of the summer growing season. In 2008, the biomass for that area was less than $50 \mathrm{~kg}$ for most of the summer with an increase to about $75 \mathrm{~kg}$ in August before declining to about $20 \mathrm{~kg}$ by the end of September. By taking the Lemna cover into consideration (fig. 6, in back of report), it would appear that in midsummer 2007 the biomass was probably closer to the high end of its range than it was during the early and late parts of that summer. In 2008, the biomass was probably in the low part of its calculated range for most of the summer.

In 2007, in the area of the Hudson impoundment near the Route 85 dam, the average biomass ranged between about 125 to $175 \mathrm{~kg}$ for most of the summer, with some midsummer values greater than that amount (fig. 13). In 2008, the average biomass remained about $80 \mathrm{~kg}$ for the entire summer. The Lemna coverage was not dense in either 2007 or 2008, and so the biomasses were probably close to the low ends of their ranges in both years.

At the Gleasondale impoundment, average Lemna biomass increased to about $60 \mathrm{~kg}$ in July 2007 and stayed at that level through August before declining with some variability in September (fig. 14). In 2008, the average biomass remained at about $25 \mathrm{~kg}$ through the summer.

At the Ben Smith impoundment on the upstream side of the White Pond Road bridge, the average Lemna biomass rose relatively steadily from about $80 \mathrm{~kg}$ in June to about $250 \mathrm{~kg}$ at the beginning of August 2007; after mid-August, the biomass fluctuated with maxima of approximately $600 \mathrm{~kg}$ and minima less than $100 \mathrm{~kg}$ (fig. 15). The fluctuations coincided with the demolition and rebuilding of the bridge; during the construction phase, rafts and barges were moved back and forth, alternately allowing and preventing Lemna to float under the bridge or to accumulate on the upstream side of the bridge. In 2008, the bridge construction was complete, and the Lemna biomass remained stable at about $80 \mathrm{~kg}$.

During 2007 and 2008, average Lemna biomass on the downstream side of the White Pond Road bridge varied in a manner similar to the biomass on the upstream side (fig. 16). After rising slowly and steadily until mid-August 2007, the biomass oscillated with maxima of about $350 \mathrm{~kg}$ and minima near $25 \mathrm{~kg}$. In 2008, the average Lemna biomass remained at about $50 \mathrm{~kg}$ throughout the summer.

The average Lemna biomass in the area just upstream of the Ben Smith dam rose gradually from about $75 \mathrm{~kg}$ in June to $200 \mathrm{~kg}$ in late July 2007 before rapidly increasing in August with the onset of the same oscillations that were observed upstream of the White Pond Road bridge (fig. 17). In 2008, the biomass did not vary much from $120 \mathrm{~kg}$.

At the Powdermill impoundment, there were no extensive accumulations of Lemna in either 2007 or 2008 (fig. 9, in back of report). In both years, the average Lemna biomass estimate was approximately $75 \mathrm{~kg}$ (fig. 18). The effect that the drawdown in the impoundment had on Lemna accumulation was not determined. 

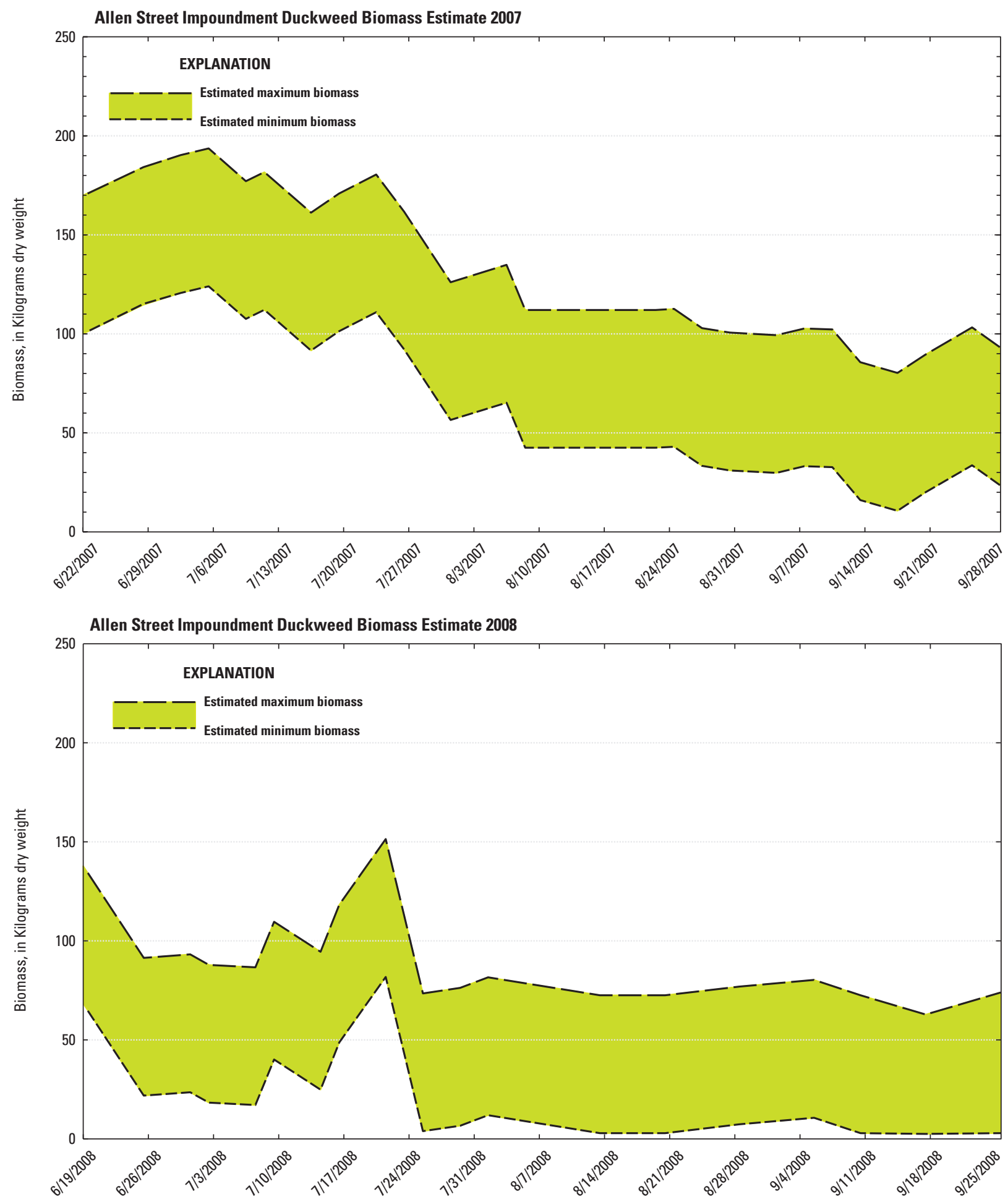

Figure 11. Range of Lemna biomass estimates for the Allen Street impoundment in 2007 and 2008 based on the Massachusetts Department of Environmental Protection areal-coverage categories. 

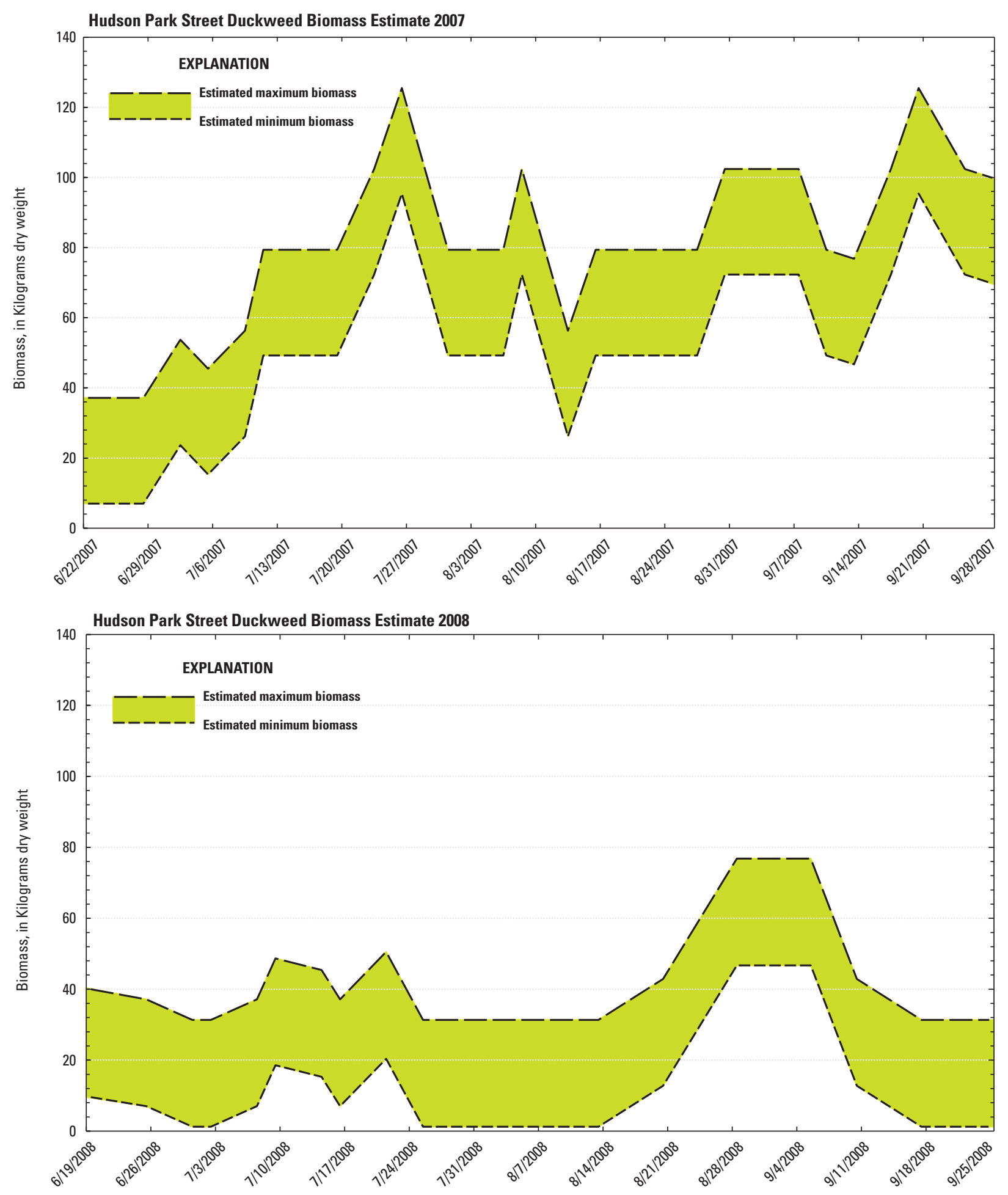

Figure 12. Range of Lemna biomass estimates for the Hudson impoundment near Park Street in 2007 and 2008 based on the Massachusetts Department of Environmental Protection areal-coverage categories. 

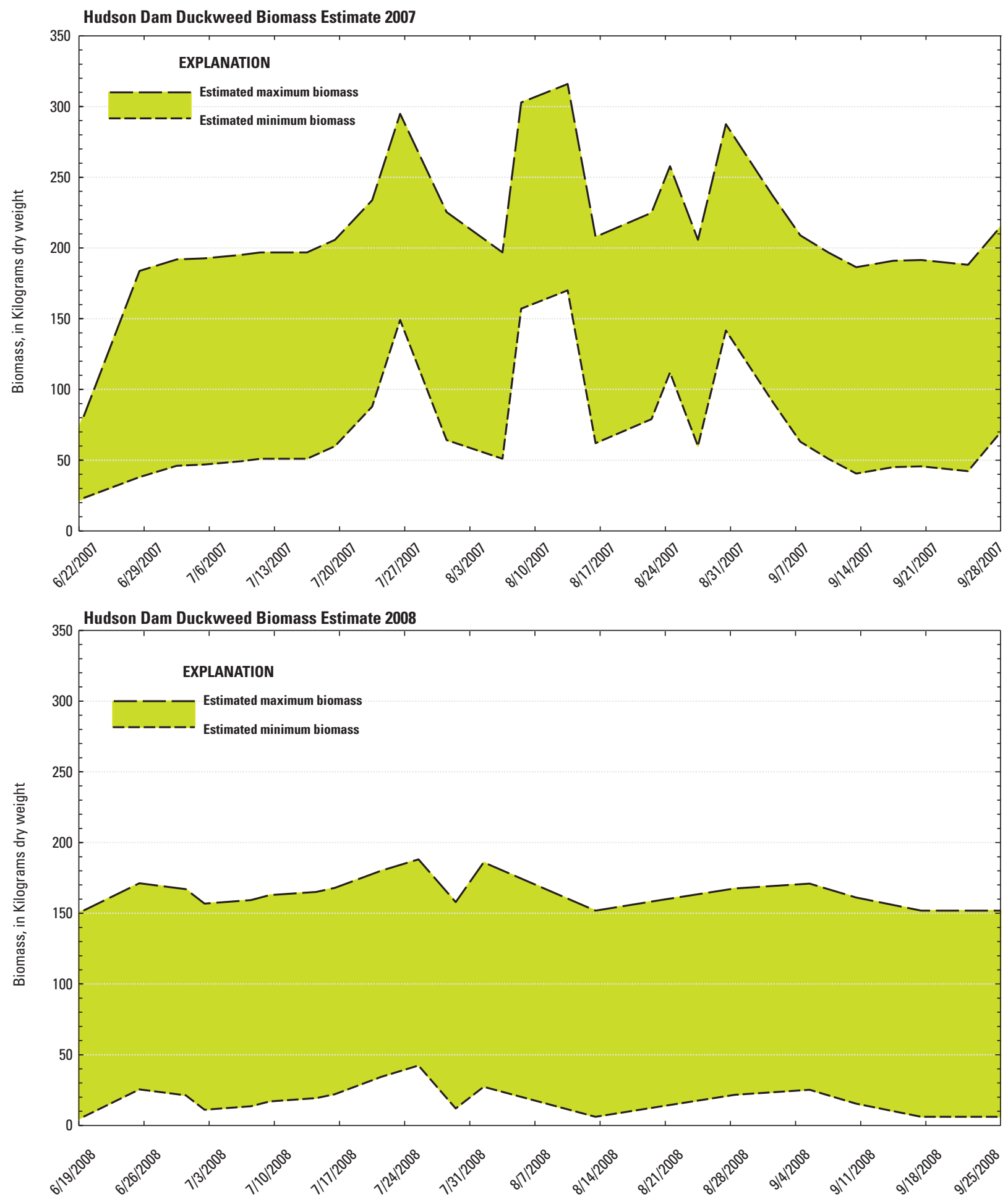

Figure 13. Range of Lemna biomass estimates for the Hudson impoundment near the Route 85 dam in 2007 and 2008 based on the Massachusetts Department of Environmental Protection areal-coverage categories. 

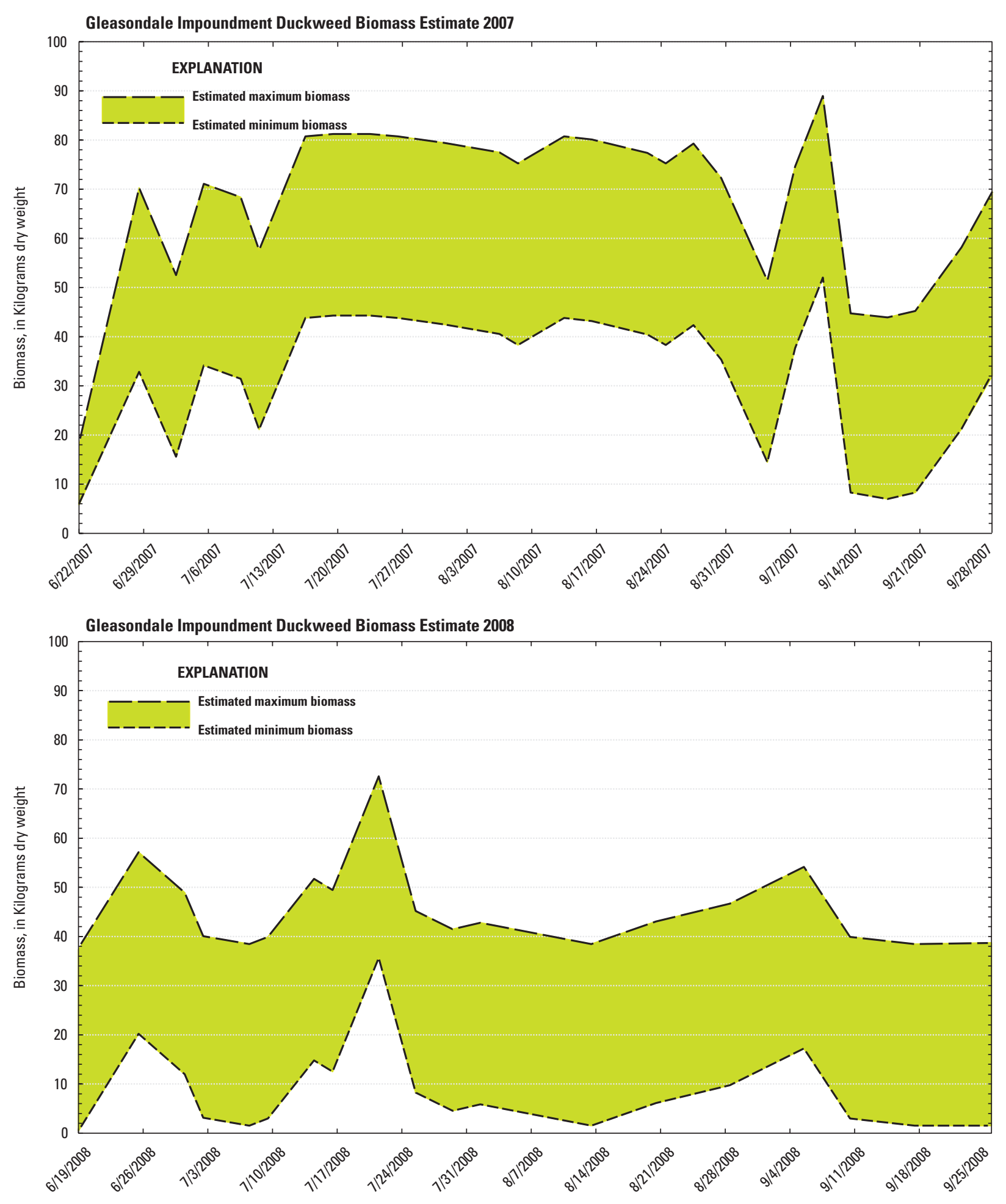

Figure 14. Range of Lemna biomass estimates for the Gleasondale impoundment in 2007 and 2008 based on the Massachusetts Department of Environmental Protection areal-coverage categories. 
Ben Smith Impoundment Duckweed Biomasss Estimate 2007 (upstream from White Pond Road)
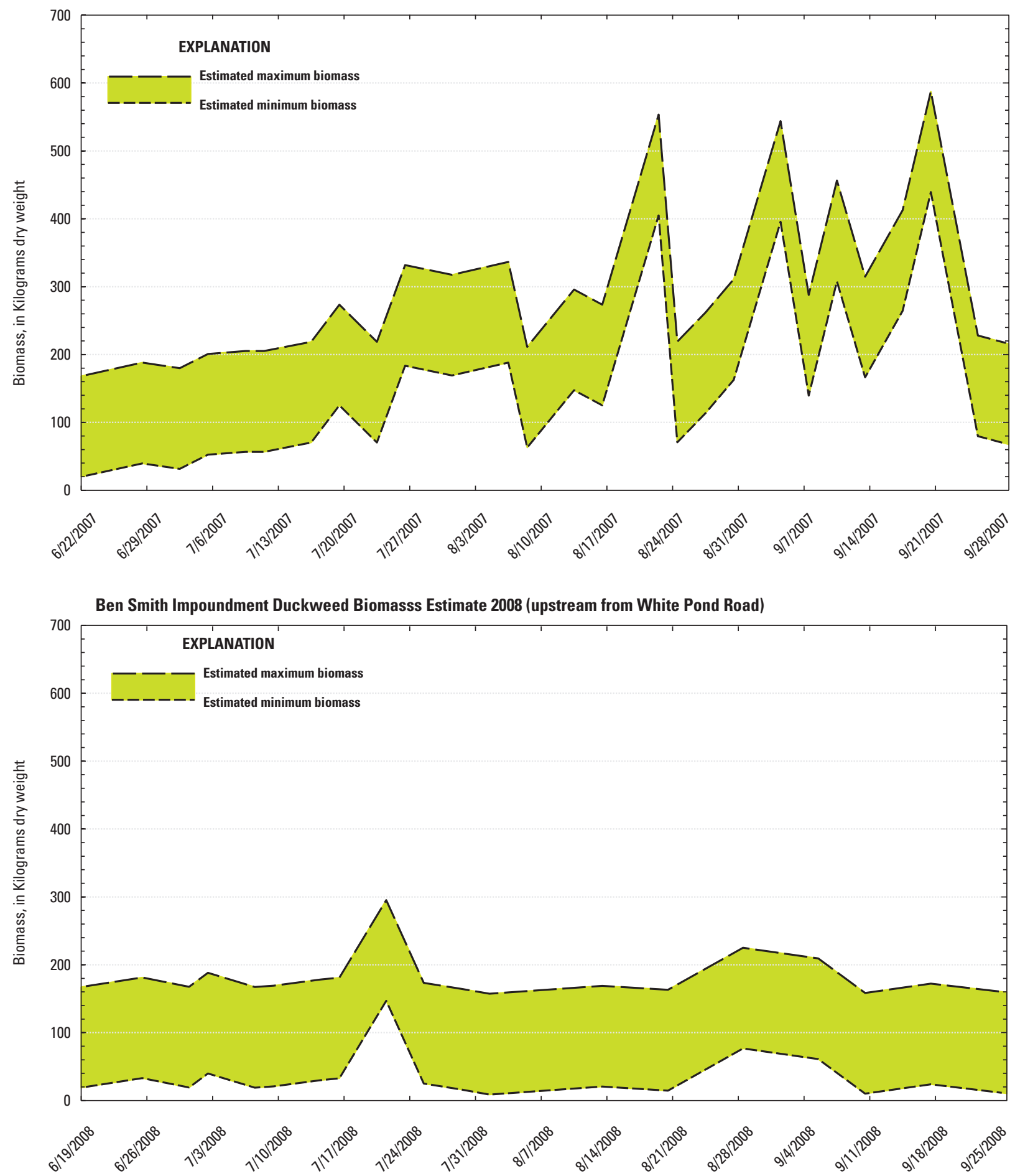

Figure 15. Range of Lemna biomass estimates for the Ben Smith impoundment upstream from the White Pond Road bridge in 2007 and 2008 based on the Massachusetts Department of Environmental Protection areal-coverage categories. 


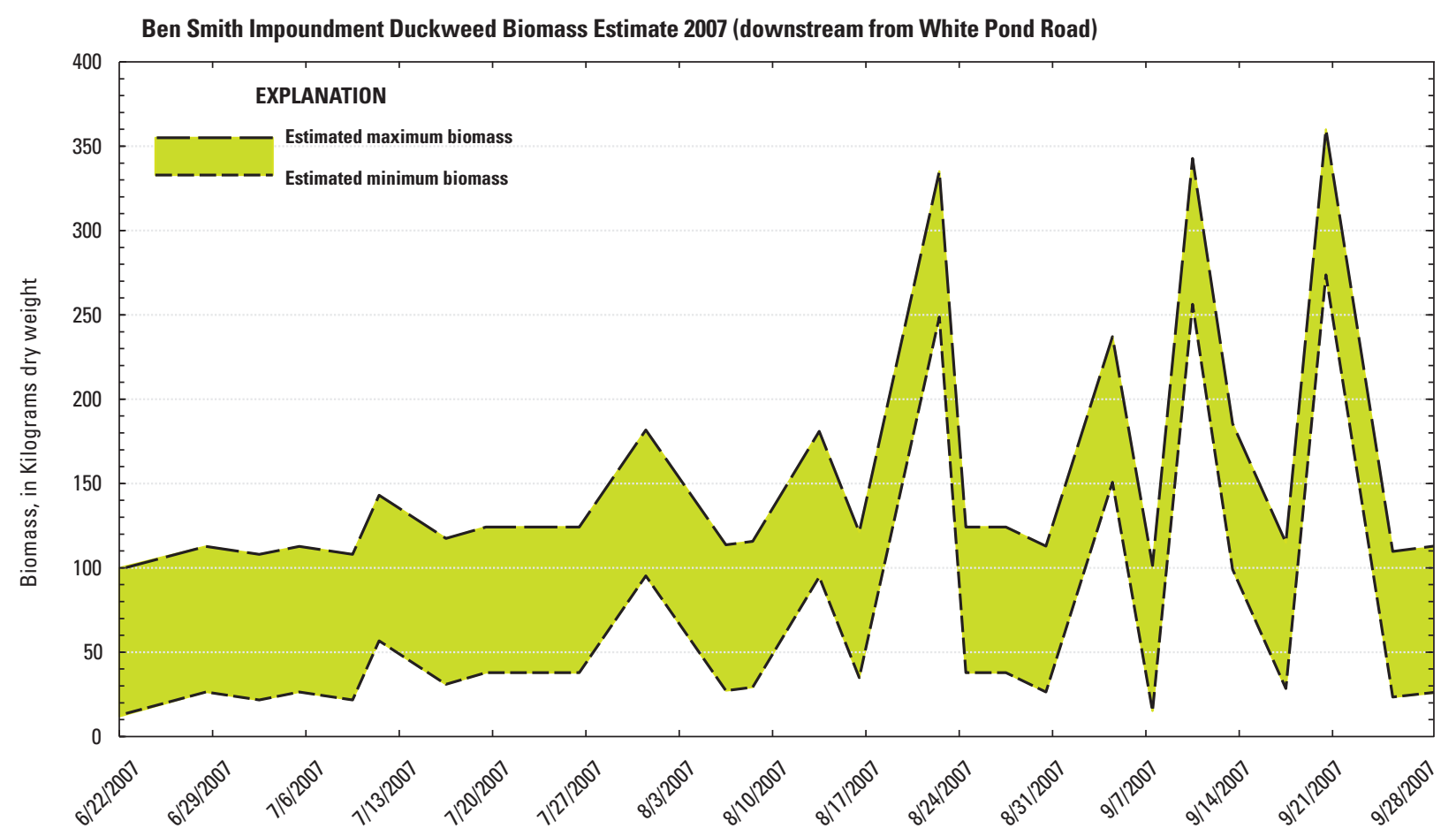

Ben Smith Impoundment Duckweed Biomass Estimate 2008 (downstream from White Pond Road)

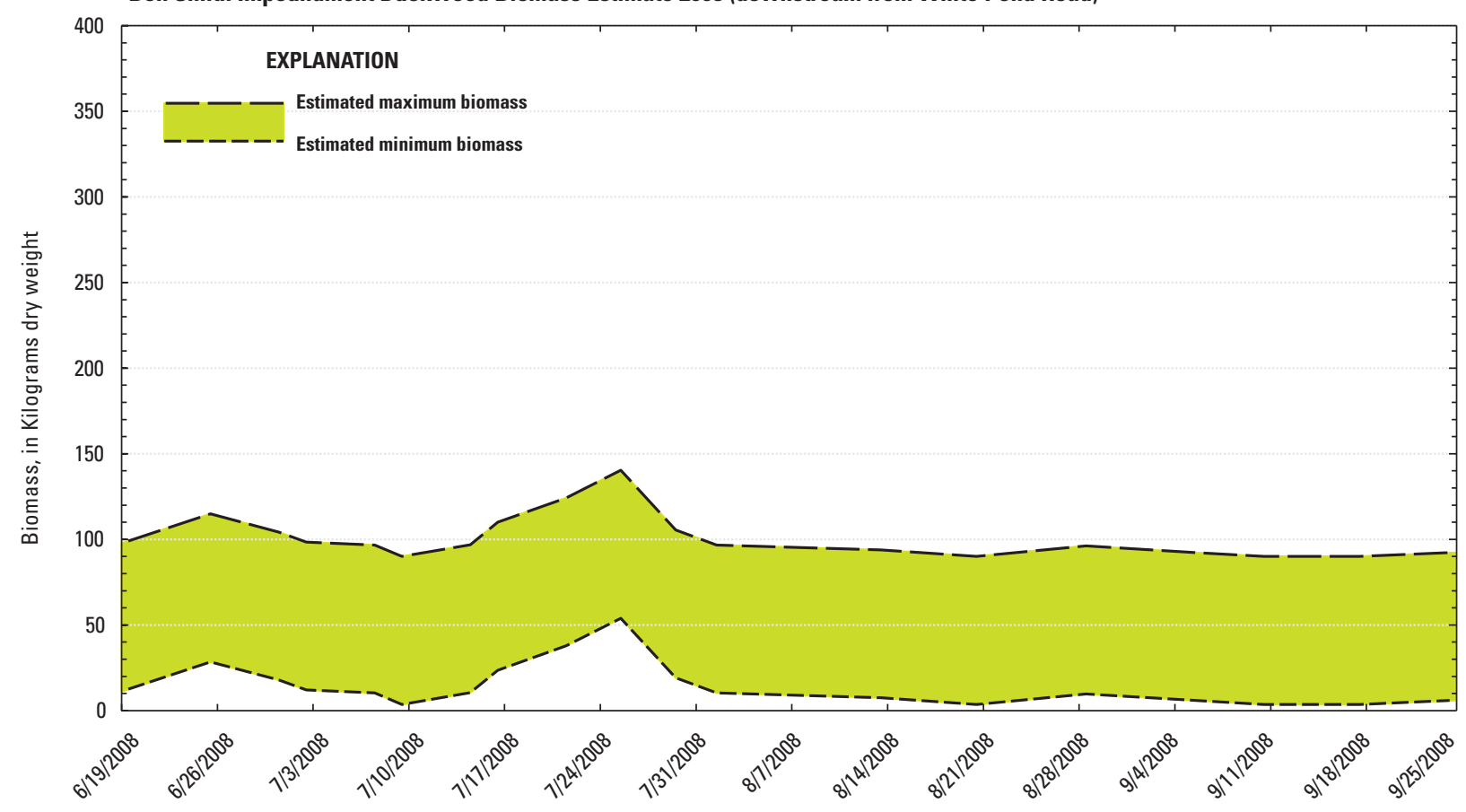

Figure 16. Range of Lemna biomass estimates for the Ben Smith impoundment downstream from the White Pond Road bridge in 2007 and 2008 based on the Massachusetts Department of Environmental Protection areal-coverage categories. 
Ben Smith Impoundment Duckweed Biomass Estimate 2007 (near dam)
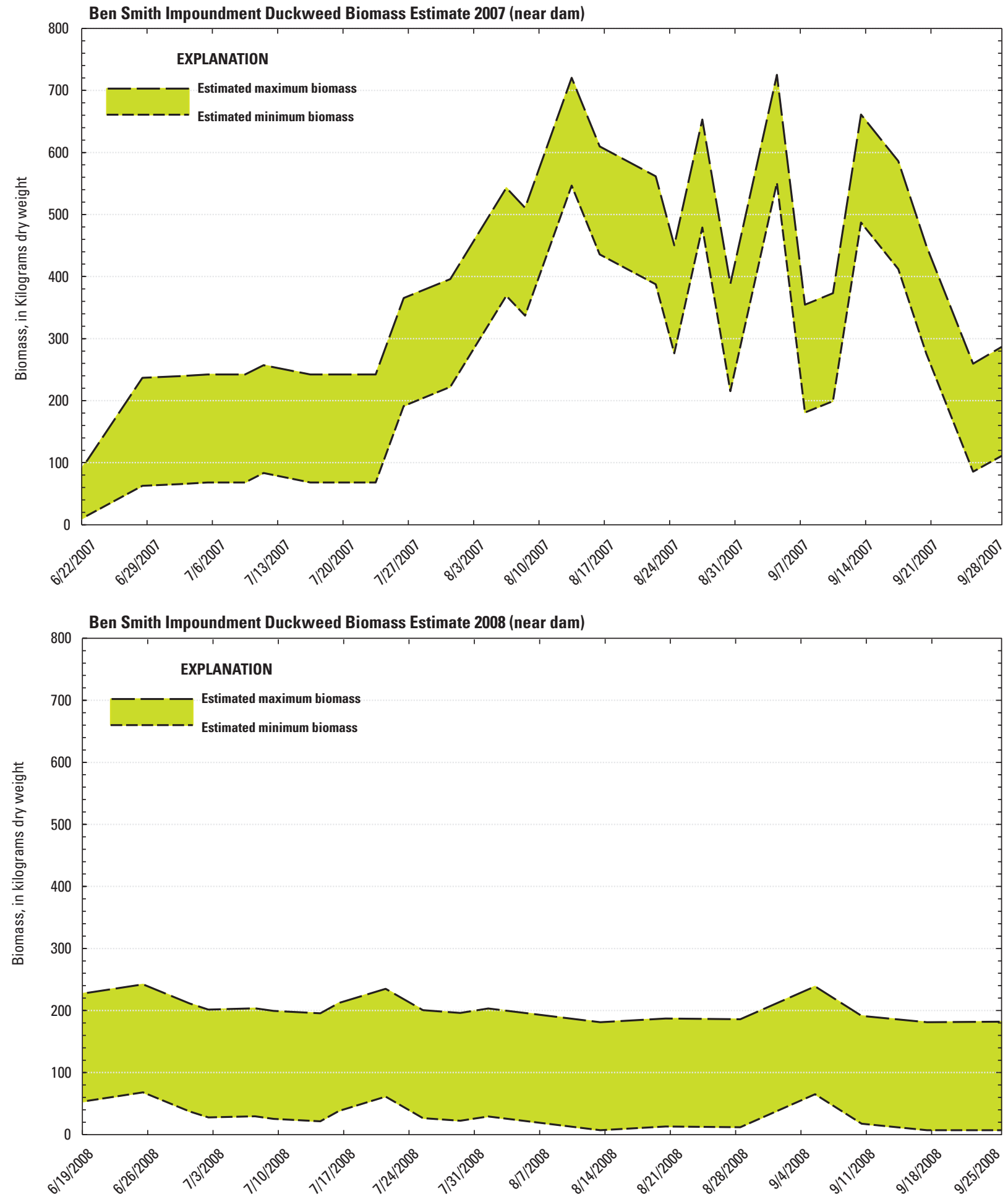

Figure 17. Range of Lemna biomass estimates for the Ben Smith impoundment near the dam in 2007 and 2008 based on the Massachusetts Department of Environmental Protection areal-coverage categories. 

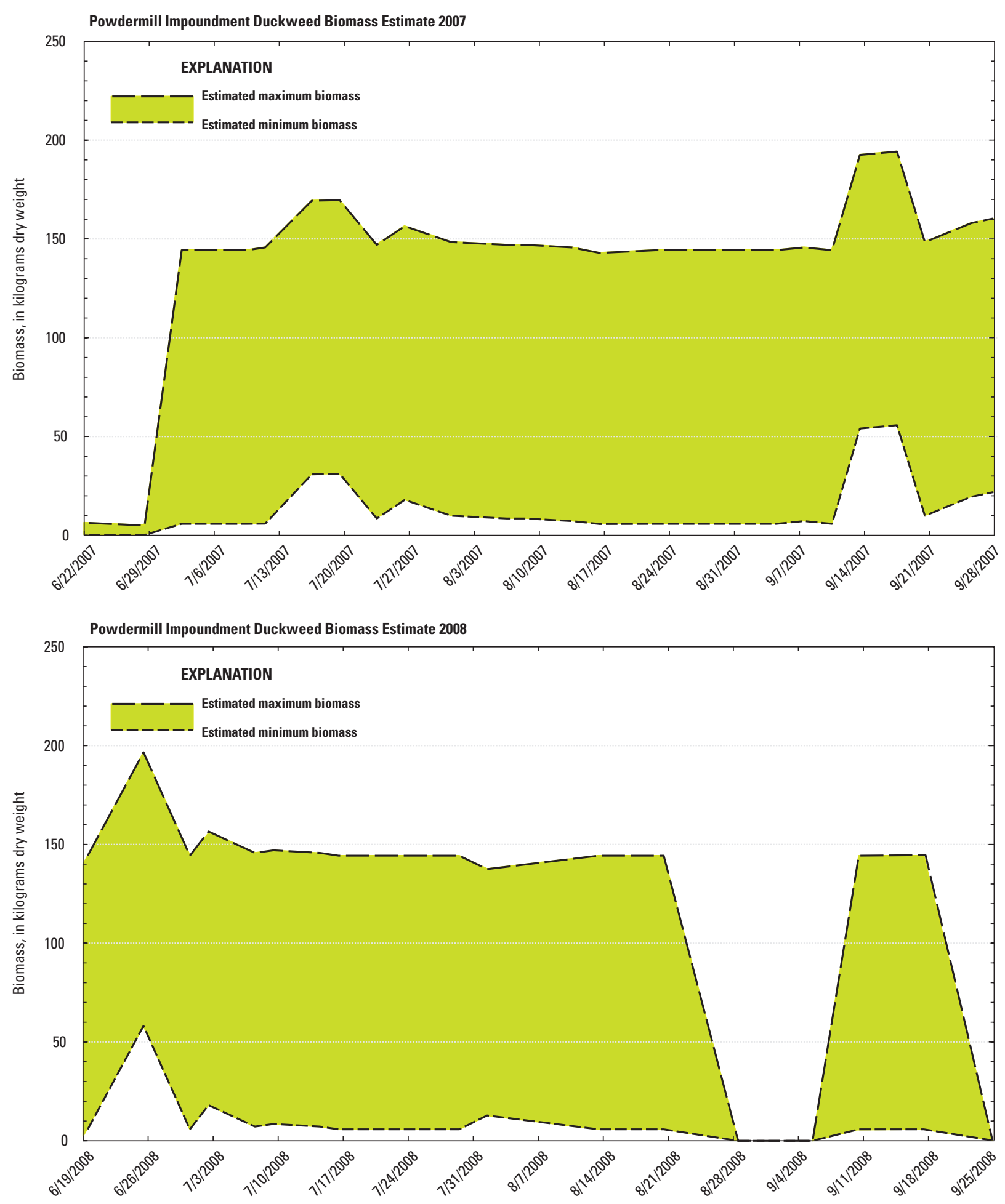

Figure 18. Range of Lemna biomass estimates for the Powdermill impoundment in 2007 and 2008 based on the Massachusetts Department of Environmental Protection areal-coverage categories. 


\section{Limitations of Different Methods for Assessing Aquatic-Plant Distribution and Biomass}

The degree of agreement between the classifications in the Allen Street, Hudson, and Gleasondale impoundments was affected by the visual-survey grids - particularly those near the riverbanks - which did not match the IKONOS images as well as expected. Discrepancies probably were derived from two known factors: geometric, georeferencing errors associated with IKONOS imagery and differences in the distributions of macrophyte associations among the impoundments. Narrow grids on the edges of small impoundments might have been particularly affected by the georeferencing error. The visual-survey grids were based on satellite orthophotos taken before our field work, and some impoundment boundaries had changed since the orthophotos were taken, especially the boundaries of the Allen Street impoundment.

In addition to these imagery-related factors that may have affected the percent agreement between the two methods of observation, it is also possible that the actual areal coverages of the aquatic macrophyte associations in the three upstream impoundments were not the same as those in the Ben Smith impoundment; as a result, application of Ben Smith NDVI values to the data for other impoundments might have produced additional discrepancies. The reflectance values of individual species are unlikely to have changed, but their fractions may not have remained the same. In the absence of additional ground-truth data for all the impoundments, definitive interpretations of the results could not be made.

One of the aims of testing the use of remote sensing to assess aquatic-plant distribution was to compare the results with those obtained from the visual observer. The results of the two approaches agree well when the same grid structure is used to classify sections of an impoundment. A degree of subjectivity, however, is associated with the visual observations but not the remote sensing approach: small, closely spaced patches of coverage in a grid section require the observer to mentally distribute the plants over the entire area before classifying the percent coverage. The satellite, with 1-m resolution, can map the distribution much more accurately than a human can. For this reason, the remote-sensing technique would be expected to provide data that would give better estimates of total coverage and therefore biomass at any given time. Of course, further development of surface-based data on aquatic-plant biomass would improve the interpretation of satellite-based estimates. One disadvantage of satellite-based, remote-sensing imagery is the absence of any guarantee of acquiring timely, high-quality data. Satellites may pass over the particular monitoring area at the proper angle during daylight hours only every few days. Furthermore, many users of remote-sensing data compete for satellite time, and the scheduling priorities of vendors can cause data-acquisition opportunities to be missed. Cloud cover, particularly in the humid summer, can also interfere with data acquisition from satellites. A potential alternative to satellite-based remote sensing is airborne imagery collected from an appropriately equipped aircraft that can fly under cloud cover and on short notice, if necessary. Low-flying aircraft can provide both hyperspectral and multispectral imagery with submeter resolution.

\section{Part 2: Phosphorus Fluxes From Assabet River Sediments}

Many factors may affect the rate of phosphorus flux from sediments. The most frequently cited factor is an oxidized microzone at the sediment-water interface, where, under aerobic conditions, oxidized iron — as an oxyhydroxide, for example - may settle or coat particles and effectively block phosphorus flux across the sediment-water interface (Wetzel, 2001). If the oxidized microzone remains intact, phosphorus flux to the water column may not occur. Thus, the sedimentoxygen demand (SOD) may control the release of phosphorus by depleting oxygen at the microzone and affecting redox conditions. SOD, in turn, is affected by temperature and ambient water velocity (Doyle and Rounds, 2003). Cooke and others (1977) showed that 65 to 100 percent of summer increases in lacustrine phosphorus concentrations could come from sediments. In addition, some studies have shown that internal loading of phosphorus from lake sediments may continue to sustain aquatic-plant growth after the diversion or treatment of wastewater (Ryding and Forsberg, 1976); moreover, the loadings could be generated under aerobic conditions, especially in shallow lakes that do not stratify. To further confound matters, Andersen (1982) determined that the presence of nitrate in concentrations exceeding $0.1 \mathrm{mg} / \mathrm{L}$ could inhibit the release of phosphorus from sediments to the anoxic hypolimnion; Tirén and Pettersson (1985) confirmed this observation and added that phosphorus flux could be enhanced after denitrification because of the increase in bacterial activity.

Most of these studies were conducted in lakes, not in shallow, run-of-the-river impoundments, such as those that constitute much of the Assabet River. The Assabet impoundments exhibit only weak thermal stratification in the summer, and their surface waters have not been found to become anaerobic (Brian Friedmann, Environmental Engineer, MassDEP, oral commun., 2009; ENSR International, 2001). Even under summer low-flow conditions, there is enough advective water movement to keep the water column mixed. Moreover, nitrate concentrations in the river exceed the concentration reported to inhibit phosphorus flux from sediments.

Phosphorus flux is typically measured in sediment cores retrieved from the field and returned to the laboratory for experimentation. Although these studies simplify manipulation for experimental purposes, making it possible to obtain high vertical-resolution results from sample collection and analysis, the cores are disturbed on removal and may not represent conditions at the sediment-water interface. In addition, temperature differences and atmospheric-gas (oxygen) exchange in open-top cores in a laboratory environment may affect experimental results. Operating in situ in closed chambers set on the 
sediment surface eliminates some of these concerns, but does not guarantee that conditions inside the chamber will remain natural; flows that replenish DO may be cut off, and the sediment surface will be disturbed to some extent. Kuwabara and others (2000) studied fluxes of metals and nutrients from sediments into the water column of Lake Coeur d'Alene in Idaho. Their study compared changes in benthic fluxes of orthophosphorus (orthoP) between incubated core samples and samples collected in situ. The in situ fluxes were substantially less than those from the incubated cores.

\section{Previous Assabet River Sediment-Flux Studies}

The USGS studied phosphorus fluxes to and from the sediments in the Assabet River periodically from July 2007 to June 2008 before the full implementation of the TMDL. Because the studies on which the TMDL was based (ENSR International, 2001) hypothesized that sediment served as a source of the phosphorus and because the TMDL, based on model simulations (ENSR International, 2005), called for a 90-percent decrease in the amount of phosphorus entering the water column from the sediment, it was important to determine the potential magnitude of the sediment-phosphorus contribution and the effects of the sediment-phosphorus flux on the overall phosphorus status of the Assabet River.

To monitor sediment-phosphorus flux from undisturbed sediments for the purpose of comparing these fluxes with those determined in laboratories and used in developing the TMDL, an in situ approach was chosen. Like the laboratory tests in which the sediment cores were manipulated to create anoxic conditions that would maximize phosphorus flux, these in situ studies were designed to generate anoxia and to measure the associated flux of phosphorus. If the improvements in phosphorus treatment at the wastewater-treatment plants prove successful, as predicted by modeling studies (ENSR International, 2005; Camp Dresser \& McKee, Inc., 2007), then the potential phosphorus flux to be measured after the upgrades are fully implemented should decrease commensurately.

Overall, 11 sampling locations were selected to include sites most likely to release phosphorus (areas with low DO concentrations) as well as areas which traditional limnological considerations would not indicate as sediment-phosphorus sources - namely, locations characterized as having relatively high DO concentrations. Water samples were collected from six sites in two impoundments and from five free-flowing river reaches (fig. 1). DO, other field parameters (temperature, specific conductance, $\mathrm{pH}$, and, initially, oxidation-reduction potential, or ORP), and phosphorus forms (TP and orthoP) were monitored routinely to provide data about the physical and chemical processes controlling phosphorus release. Most of the samples were collected during the summer (July and August 2007), but some samples were collected in the late spring (June 2008) and fall (November
2007). Hazardous icy conditions in the winter precluded the collection of samples.

To isolate the potential sediment contributions of phosphorus, flux chambers were manually placed on the sediment surface. Water samples were withdrawn from the chambers by using methods slightly modified from Zimmerman and others (2005) and from pore water below the sediment surface under the chambers for periods ranging from a few hours to a few days. Phosphorus concentrations in samples collected from the surrounding surface water were compared with the potential magnitude of the sediment-phosphorus contribution. TP and orthoP were analyzed from all samples collected.

ENSR International (2001) collected bottom-sediment samples from the Assabet River and studied the rates of phosphorus release or sequestration. ENSR International (2005) also used computer simulations to predict the decreases in phosphorus fluxes that would be required for the river to achieve the water quality associated with its designated use. For conditions preceding wastewater-treatment-plant upgrades, the simulations used $12.0 \mathrm{mg}$ phosphorus per square meter per day $\left(\mathrm{mg} \mathrm{P} / \mathrm{m}^{2} /\right.$ day) for orthoP fluxes from the upstream impoundments and $21.6 \mathrm{mg} \mathrm{P} / \mathrm{m}^{2} /$ day for fluxes from the downstream impoundments, regardless of specific local characteristics such as depth, sediment characteristics, stream velocity, water chemistry, dissolved oxygen concentrations, and temperature. The Gleasondale Dam in Stow was designated the dividing line between the upstream and downstream sections of the river.

CDM, in an additional modeling study for the USACE, considered the effects of wastewater-treatment-plant upgrades, dredging, and dam removal on the reduction of phosphorus in the Assabet River impoundments. Of relevance to the present study, CDM found that wastewater-treatment-plant upgrades, by reducing phosphorus concentrations in effluents, could result in a 60-percent reduction in sediment release of phosphorus.

\section{Flux-Chamber Design and Testing}

The studies done to provide data for the development of the TMDL used sediment cores collected from the Assabet River and incubated in laboratories under varied temperature regimes (ENSR International, 2001); some of the cores were capped to initiate the development of anaerobic conditions. In the present study, flux chambers were placed on the river bottom, and water-quality parameters were monitored. During initial equipment testing, some conditions in the chambers were manipulated; during the study, however, to prevent or minimize effects on the flux rates, conditions in the chambers were not deliberately manipulated. Of course, deploying a chamber that isolated an area of sediment and its overlying water modifies the conditions that would affect sedimentphosphorus flux in open water. 


\section{Chamber Design}

Conceptually, the flux chamber used in this study may be thought of as a hybrid that combines features of an SOD chamber (Sonzogni and others 1977; Caldwell and Doyle, 1995; Rounds and Doyle, 1997; and Wood, 2001) and a seepage meter (Lee, 1977). Based on the SOD-chamber design described by Caldwell and Doyle (1995), the instrumentation monitors DO depletion over time as organic matter in the sediments and chamber is oxidized. Similar to a seepage meter, the flux chamber provides a means for sampling water-quality constituents transported across the sediment-water interface by possible groundwater inflow and diffusion (Lee, 1977). Advective transport of water-quality constituents is blocked; however, with the design that was implemented, ambient concentrations were measured according to the sampling schedules.

The chambers used in this study consisted of a pair of inverted 19-L (5-gal) plastic buckets, one inside of the other, creating a sampling chamber inside the inner bucket and a space between the bottoms of the buckets (figs. 19 and 20). An external metal frame held the buckets together and provided sufficient mass to hold the chamber in place on the sediment surface. A toilet flap valve allowed water to displace air from the sampling chamber (the inner bucket) when the chamber was deployed; the exterior bucket was vented to allow the air to leave the apparatus. Two 10-foot (ft)-long SedPoint samplers (M.H.E. Products, East Tawas, Michigan, http://www.mheproducts.com/SedPoints.pdf; figs. 19 and 20) passed through the bottoms of the buckets and into the sampling chamber. (The SedPoint sampler is a $0.63-\mathrm{cm}(1 / 4-$ in.) polyethylene tube with a polypropylene screen at the tip; the screen's mesh has square openings $0.0003 \mathrm{~m}$ (0.0117 in.) on a side.) When inverted, the rim of the chamber rested on the river bottom with the screened tip of one SedPoint sampler penetrating the sediment approximately $5 \mathrm{~cm}$ to sample pore-water phosphorus and the other SedPoint sampler in the middle of the sampling chamber to enable monitoring of phosphorus flux. A third SedPoint sampler, fastened to the chamber's external frame, was used to sample ambient phosphorus concentrations. A small submersible pump, attached to the top of the sampling chamber and powered by an external battery pack, circulated water in the chamber. To provide a better understanding of the changes taking place in the chamber near the sediment-water interface, a YSI 600XL Multi-Parameter Water Quality Sonde that was installed through the bucket bottoms recorded $\mathrm{DO}$, temperature, specific conductance, $\mathrm{pH}$, and, on occasion, ORP data.

\section{Sampling Methods}

Samples were collected by attaching a peristaltic pump to the three SedPoint samplers. After purging with approximately $1 \mathrm{~L}$ of ambient water, $125-\mathrm{mL}$ samples were collected for analysis of TP and orthoP. The TP sample was acidified immediately with $1 \mathrm{~mL} 0.45 \mathrm{~N}$ sulfuric acid. The orthoP sample was filtered through a 0.45 -micron syringe filter before being collected in the sample bottle. All samples were immediately placed on ice before refrigerator storage and shipping to the USGS National Water Quality Laboratory for analysis. All chemical water-quality data are accessible through the USGS National Water Information System (http://waterdata.usgs.gov/ $\mathrm{ma} /$ nwis/nwis).

In addition to the environmental phosphorus samples, quality-control equipment-blank and sequential duplicate samples were collected. In accordance with the Quality Assurance Project Plan prepared for the MassDEP, qualitycontrol samples composed about 10 percent of the total environmental samples collected. TP and orthoP blank-sample concentrations were all less than the minimum reporting levels of 0.008 and $0.006 \mathrm{mg} / \mathrm{L}$, respectively. The median relative percent differences (RPD) between the sequential duplicate TP quality-control samples, the sequential duplicate orthoP quality-control samples, and their corresponding environmental samples were 7.5 percent and 6.2 percent, respectively; 19 pairs of these quality-control samples were analyzed. RPD values for TP ranged from 0.5 to 158 percent and, for orthoP, from 0.0 to 155 percent. If the two highest values for both TP and orthoP are dropped, the TP median declines to 7.0, and the orthoP median declines slightly to 6.15 percent. The range of the RPD for TP becomes 0.5 to 50.8 percent and, for orthoP, 0.0 to 56.5 percent. Five of the TP RPDs and three of the orthoP RPDs exceeded the QAPP maximum of 10 percent.

\section{Chamber Testing}

Prior to deploying the flux chambers, a series of laboratory and field tests were run to evaluate the functionality of the chambers. The multiparameter sonde was used to monitor the chamber's operation during these tests.

\section{Proof-of-Method Laboratory Test}

The first experiment used a tub of water to which top soil had been added to simulate sediment. When the top soil had settled, one of the flux chambers was submerged in the tub, and DO and specific conductance were monitored for more than 7 hours (h) (fig. 21). After approximately $5 \mathrm{~h}$, when the DO concentration was just above zero, about $20 \mathrm{~L}$ of deionized water was pumped into the chamber through one of the SedPoint tubes over a period of 30 minutes. The specific conductance dropped, and the DO concentration increased. After another hour, the DO concentrations started to fall rapidly, and the specific conductance started to increase. These results demonstrated that, even within a relatively short time period, the decay of organic matter inside the chamber could deplete the DO and create conditions favorable for the release of dissolved ionic material, such as orthoP, from sediments. 


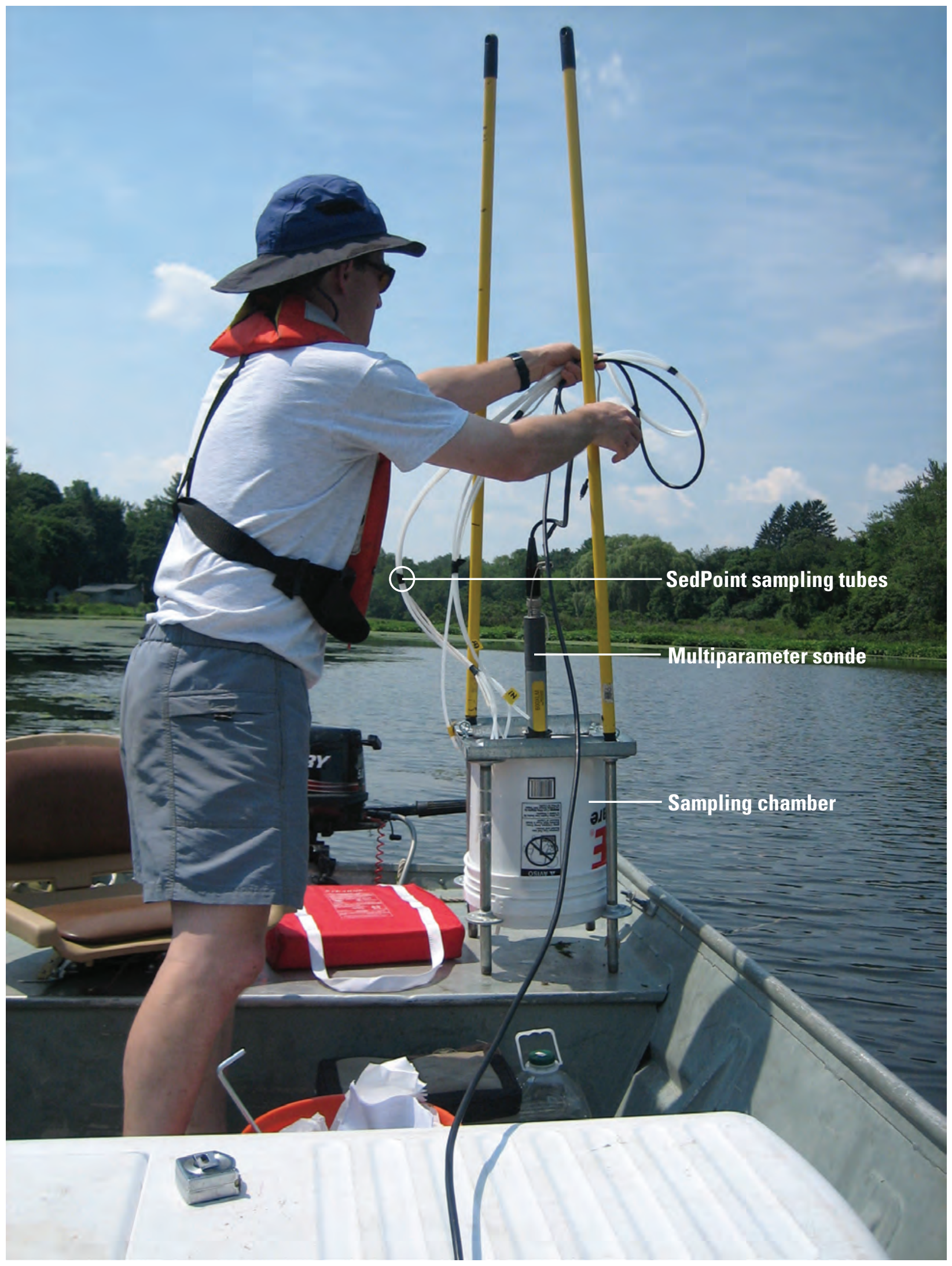

Figure 19. U.S. Geological Survey personnel preparing to deploy the sediment-phosphorus flux chamber. 


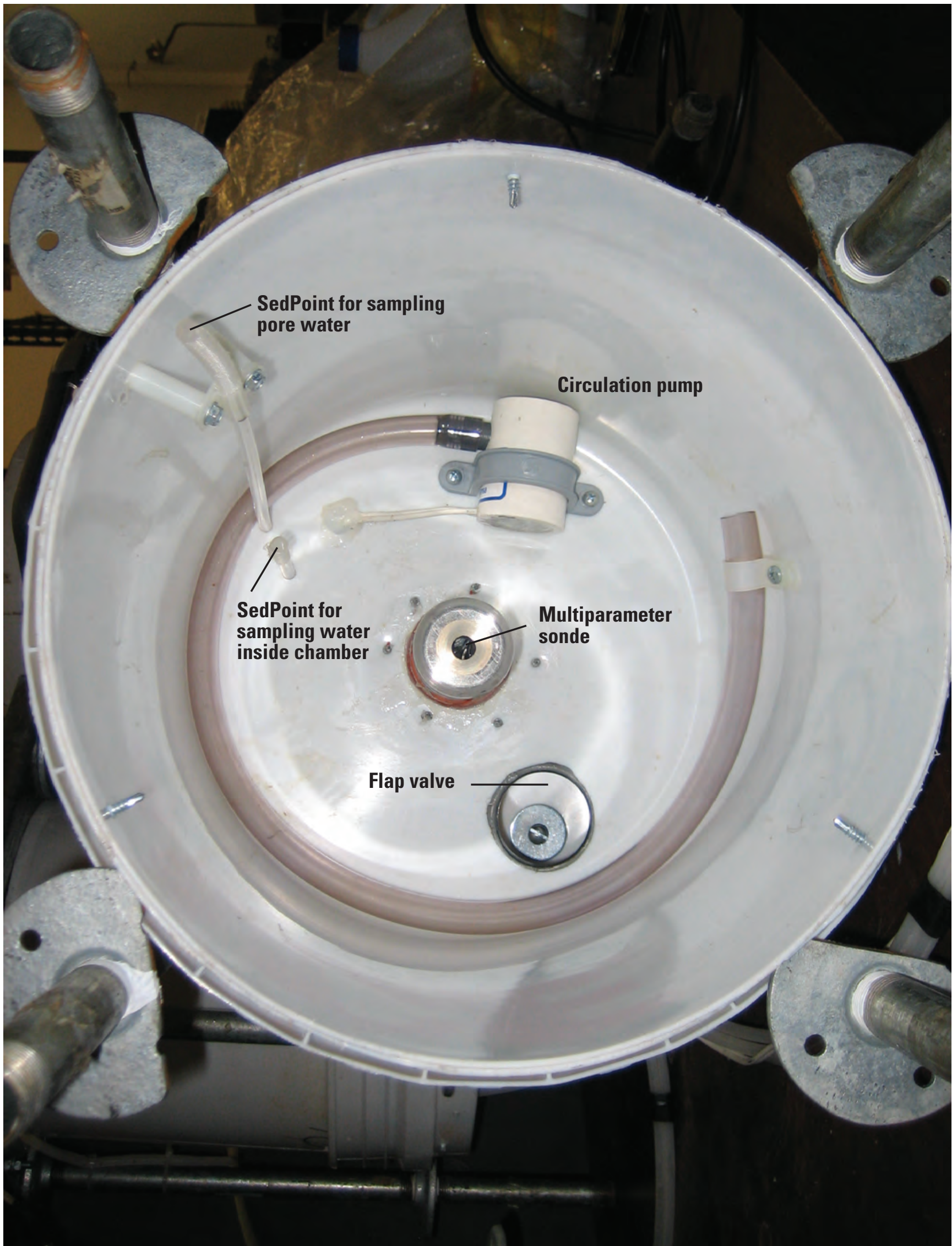

Figure 20. Internal components of the sediment-phosphorus flux chamber. 


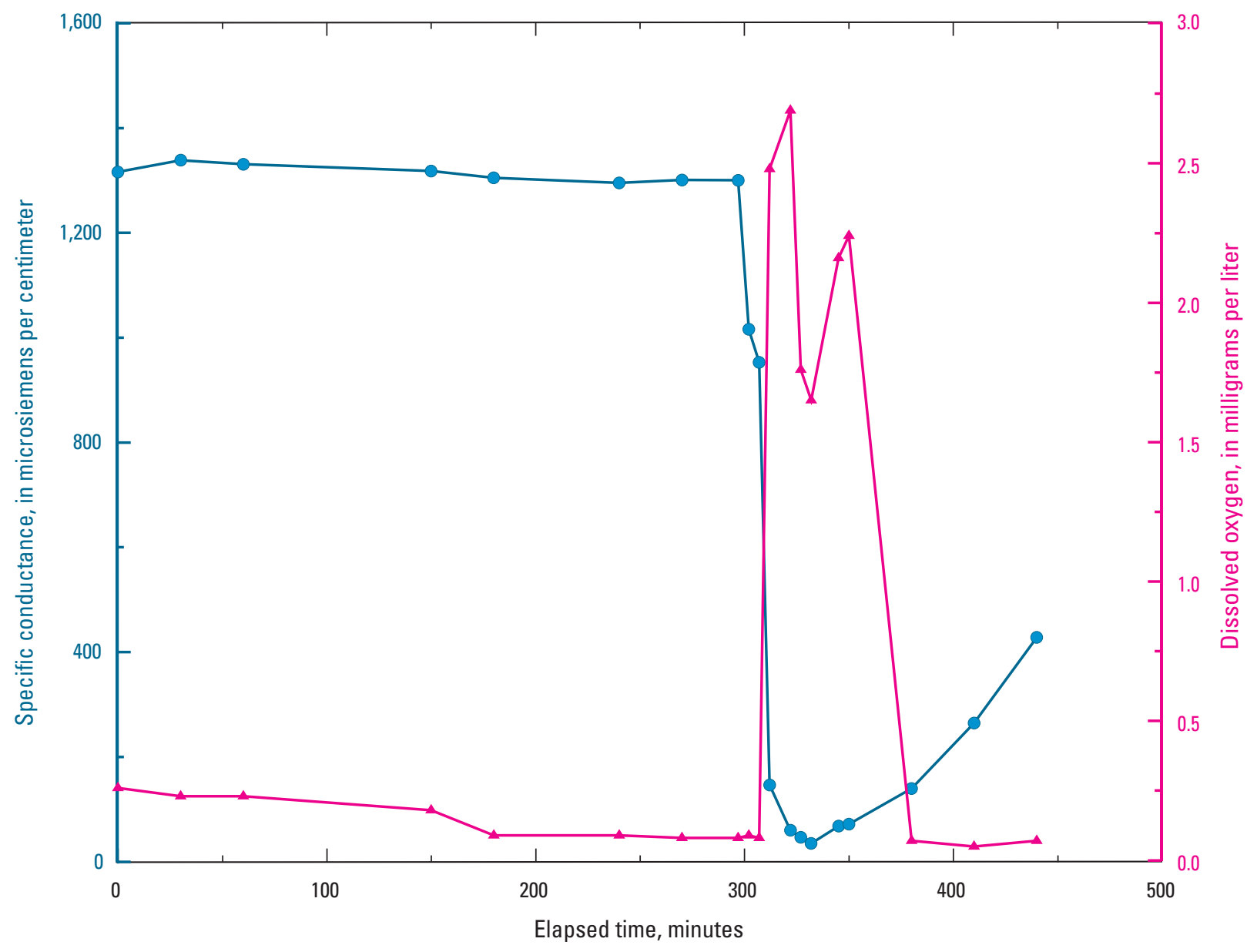

Figure 21. Changes in specific conductance and dissolved oxygen concentrations during laboratory testing of the sediment-phosphorus flux chamber.

\section{Field Tests}

Following successful completion of the laboratory testing, the chambers were taken to field locations for further testing. Field procedures were similar to those used in the laboratory.

\section{Field Test 1}

The first field-test site was next to a private dock on the Hudson impoundment (fig. 22). In this test, the DO concentration and ORP were monitored for about $2 \mathrm{~h}$. During this period, the DO concentration decreased from $6.6 \mathrm{mg} / \mathrm{L}$ to about 1 to $1.5 \mathrm{mg} / \mathrm{L}$. ORP decreased from about -30 to $-90 \mathrm{mV}$ (fig. 23). The water temperature in the chamber declined from 20.25 to $19.28^{\circ} \mathrm{C}$. The DO and ORP results indicate conditions approaching anoxia- a state favorable for reduction reactions and sediment flux of phosphorus.
Field Test 2

The second test was conducted at the same Hudson impoundment site. This test lasted for slightly more than 3 h. Unlike the first field test, ORP remained at about its initial level between -30 and $-40 \mathrm{mV}$ until the last reading, when it dropped to about $-85 \mathrm{mV}$ (fig. 24). The DO concentration started to decline from the outset, increased slightly after about 45 minutes, and was nearly zero at the end of the test. The water temperature in the chamber declined slightly-from 17.11 to $17.05^{\circ} \mathrm{C}$. The cause of the ORP stability is uncertain, but it could have been a problem with the probe that corrected itself near the end of the test when the ORP dropped rapidly. The brief increase in the DO concentration may have been caused by movement of the chamber, but that also is uncertain. 


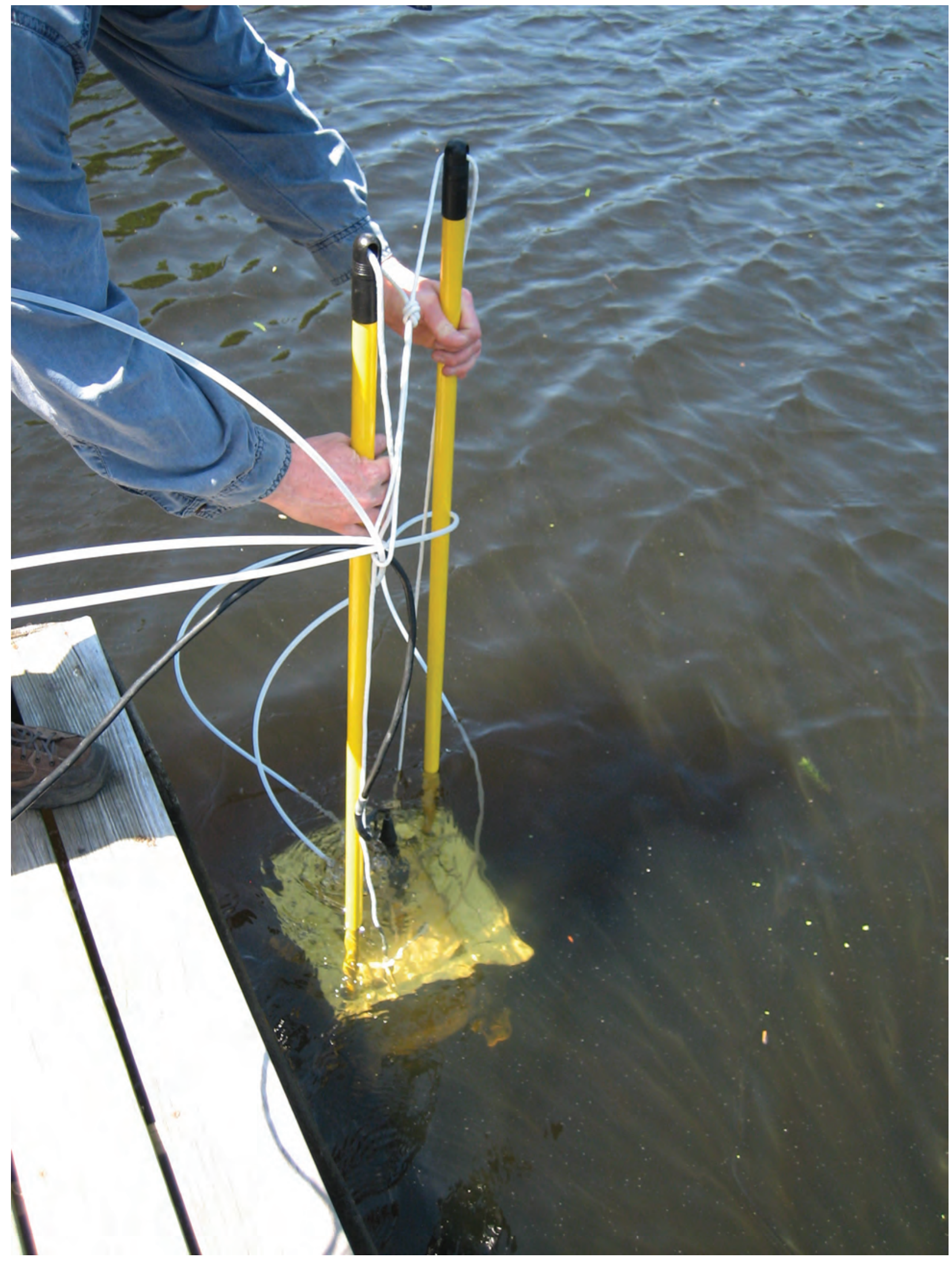

Figure 22. U.S. Geological Survey personnel deploying the sediment-phosphorus flux chamber for the first field test. 


\section{TEST 1}

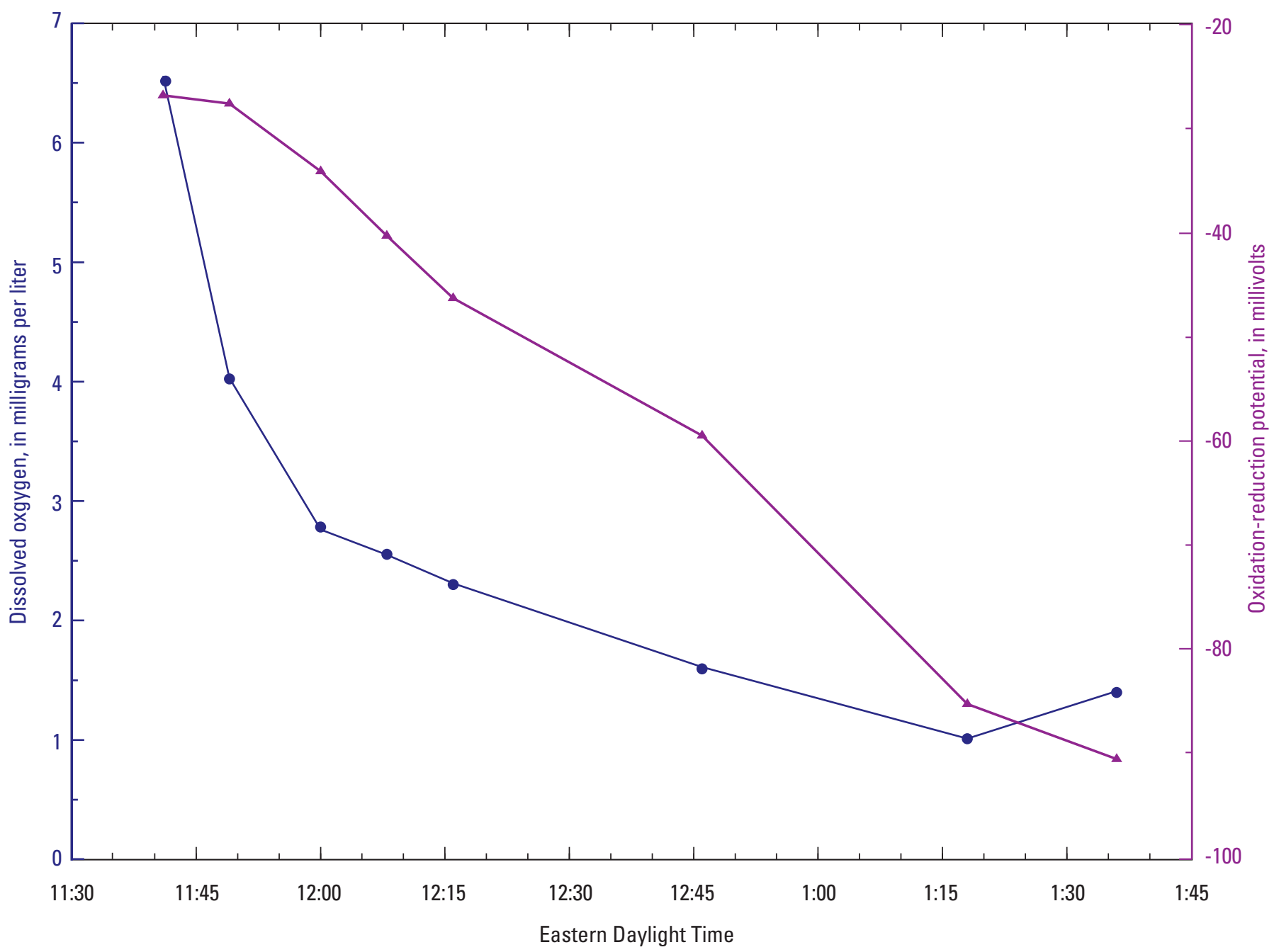

Figure 23. Changes in dissolved oxygen concentration and oxidation-reduction potential during the first field test of the sedimentphosphorus flux chamber.

\section{Field Test 3}

In this test that lasted about $5 \mathrm{~h}$ and was conducted at a private dock on the Ben Smith impoundment, DO and ORP were monitored continuously, and water in the chamber was flushed out with deionized water after about $4 \mathrm{~h}$ (fig. 25). The DO concentration decreased from $7 \mathrm{mg} / \mathrm{L}$ to less than $1 \mathrm{mg} / \mathrm{L}$ in about $3.5 \mathrm{~h}$, after which deionized water was pumped in, and the DO concentration returned to about $7 \mathrm{mg} / \mathrm{L}$ before decreasing to less than $2 \mathrm{mg} / \mathrm{L}$ at the end of the experiment. The decline in the initial DO concentration accelerated after the chamber's position on the sediment was adjusted slightly, possibly preventing infiltration of oxygenated ambient water, after about $0.5 \mathrm{~h}$. The ORP varied greatly, dropping from approximately $100 \mathrm{mV}$ to less than $20 \mathrm{mV}$ in about $0.5 \mathrm{~h}$ and then rising to greater than $80 \mathrm{mV}$ before falling again to almost $0 \mathrm{mV}$. Prior to the addition of the deionized water, the water temperature inside the chamber declined from 21.74 to $19.54^{\circ} \mathrm{C}$. When the deionized water was pumped into the chamber, the ORP rose to $100 \mathrm{mV}$ but was starting to decline when the experiment was terminated. Like the DO concentration, the ORP decreased relatively rapidly after the chamber's placement was adjusted; the reason for its subsequent increase after about $1 \mathrm{~h}$ is not understood.

The field and laboratory tests satisfactorily demonstrated the utility of the flux chamber for monitoring phosphorus flux from Assabet River sediments; moreover, the additional information obtained from the continuous sonde measurements supplied ancillary data useful in interpreting the phosphorusflux data. 


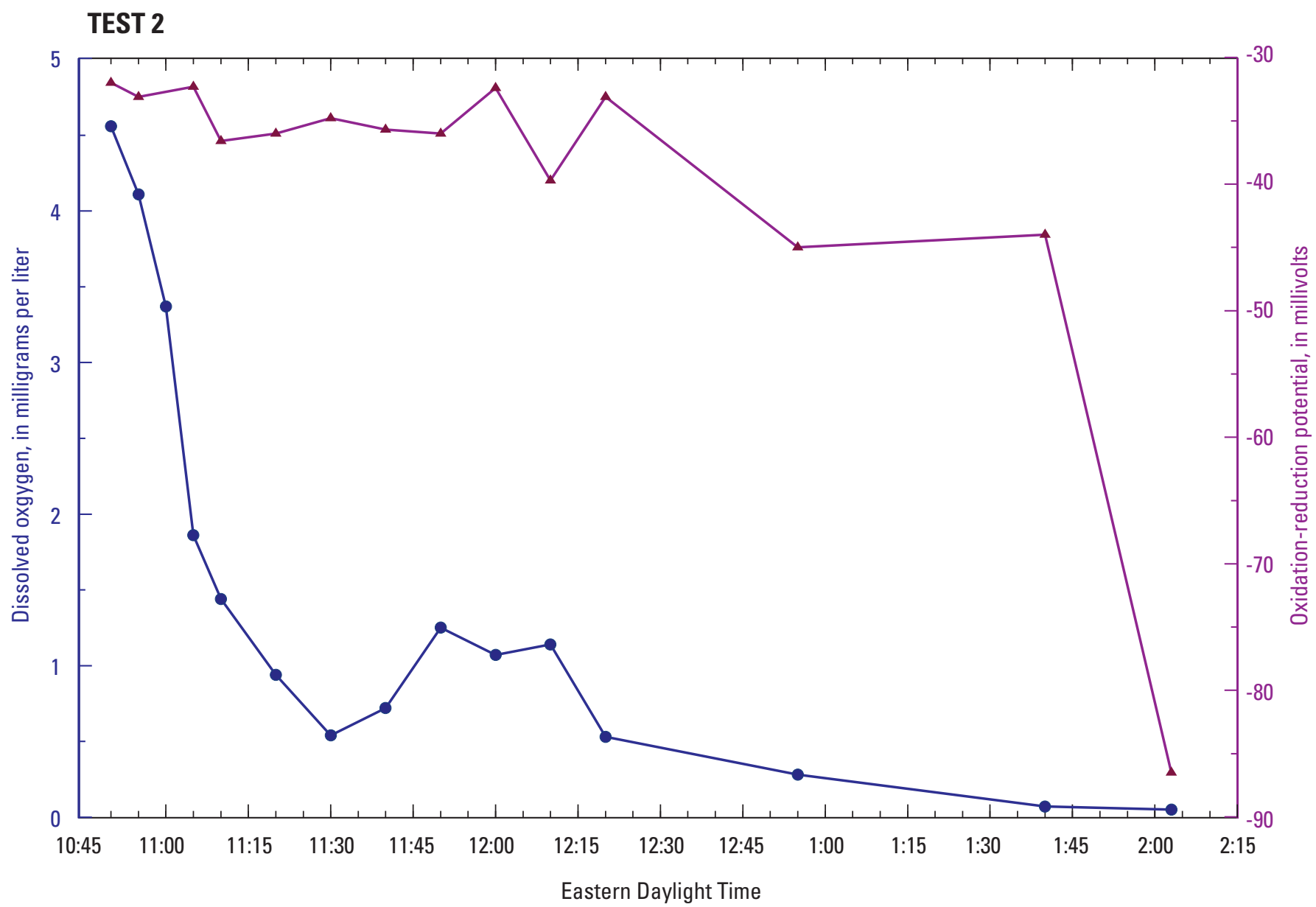

Figure 24. Changes in dissolved oxygen concentration and oxidation-reduction potential during the second field test of the sedimentphosphorus flux chamber.

\section{Results of Sampling in Free-Flowing and Impounded Reaches}

Water-quality samples were collected on a routine basis according to the duration of the field work in July, August, and November 2007, and in June 2008. At first, two or three sites were visited on a circuit three times during the course of a single day. Sample collection required driving either a car to wadeable sites (on free-flowing reaches) or a boat on an impoundment (impounded reaches). After the first round of sampling, the chambers were left unattended and samples were collected daily Monday through Friday. In addition to TP and orthoP samples, temperature, specific conductance, DO, $\mathrm{pH}$, and occasionally ORP data were collected.

Sediment-phosphorus-flux rates were calculated using changes in concentrations and the physical characteristics of the chamber. The concentration values were multiplied by the water volume in the chamber to give the total mass of phosphorus in the chamber; these results were divided by the sediment-surface area and the time between samples to yield a flux rate.

The sediment-phosphorus-flux data from the National Water Quality Laboratory indicated that initial phosphorus concentrations were consistently high — an artifact caused by the initial disturbance of the sediment associated with emplacement of the flux chamber (see figs. 26-31); similar results have been reported elsewhere in association with initial rates of SOD (Doyle and Lynch, 2005). For this reason, the phosphorus-flux-rate data reported here do not include the changes between the first and second sample collections at each site during each round of sampling. Two other calculated fluxes were excluded because of evidence that the flux chamber had been disturbed. 


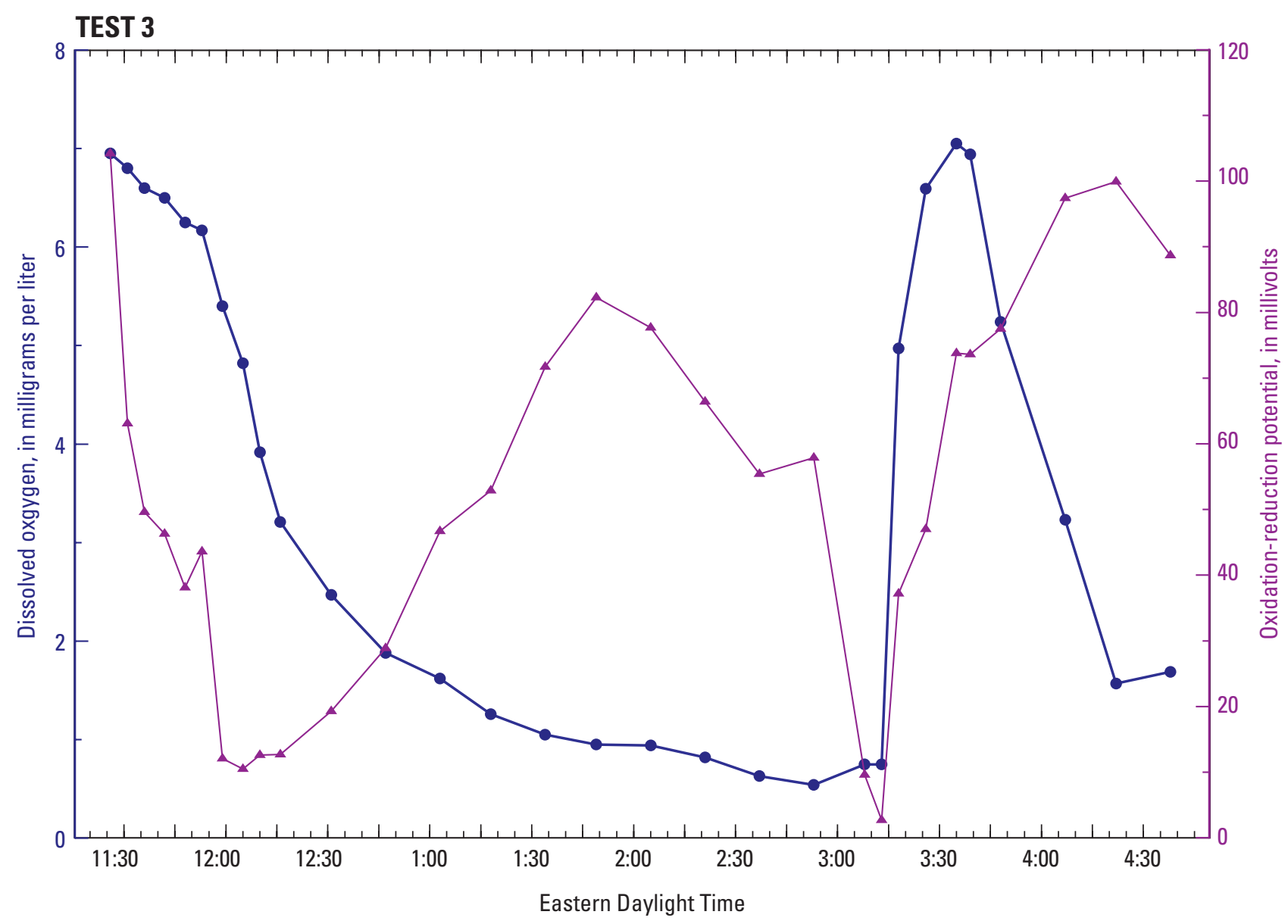

Figure 25. Changes in dissolved oxygen concentration and oxidation-reduction potential during the third field test of the sediment-phosphorus flux chamber.

\section{Total Phosphorus and Orthophosphorus Concentrations in Free-Flowing Reaches}

The first round of sampling in the free-flowing reaches of the Assabet River in July and August 2007 took place at five sites (fig. 1): one each in Westborough (at the Westborough wastewater-treatment plant, upstream from the effluent discharge), Northborough (at School Street, the first study site downstream from the Westborough wastewater-treatment plant), Marlborough (at Robin Hill Road, near a public access point downstream from the Marlborough Westerly wastewater-treatment plant), Hudson (at Cox Street, upstream from the Hudson wastewater-treatment plant ), and at two sites in Maynard (both sites near the Maynard Elks Club, between the Ben Smith dam and the Maynard wastewater-treatment plant). Upon further evaluation, for reasons of security, accessibility, and safety, the number of sites in free-flowing reaches during the second and third rounds of sampling in
November 2007 and June 2008 was reduced to the two sites in Westborough and Northborough.

In sediment pore water where SOD creates reducing conditions, more phosphorus would be expected to be in the dissolved form than in the water column. This dissolved phosphorus and any phosphorus associated with ferric oxyhydroxides would serve as a dissolved-phosphorus reservoir that could be released into the water column if anoxic conditions develop and could break down the oxidized microzone at the sediment-water interface. (Although the existence of iron-rich, oxidized microzones in the Assabet River impoundments was not investigated here, Zimmerman and Sorenson (2005) found that surficial-sediment samples in the impoundments generally had iron concentrations higher than 1 percent by mass. In all likelihood, a substantial portion of this iron would have been in the oxidized form.) Surficial sandy sediments with low organic content would be less likely to become anoxic than organic-rich sediments, and aerated water could circulate in the hyporheic zone and inhibit phosphorus flux. 
In general, the initial round of short-period studies showed that the highest concentrations of TP and orthoP at each sampling site were usually measured in samples collected from pore water, and that the pore-water TP concentrations generally decreased in the downstream direction (figs. 26AF). Ambient concentrations (in the water column, outside the chamber) were generally the lowest.

Inside the chambers, DO concentrations declined from initial conditions at all sites, but the final concentrations did not drop below $2.5 \mathrm{mg} / \mathrm{L}$ at any of the sites. The short duration of these studies and concomitant maintenance of relatively high DO concentrations probably combined to suppress phosphorus flux into the chambers. The free-flowing condition may also have enhanced transport of DO through the hyporheic zone and into the chambers.

The patterns in the data from the second round of sampling in November 2007 (fig. 27) were similar to those from the first round. The highest TP concentrations were detected in the pore water, and the other concentrations changed little. In general, the DO dropped - to about $1.5 \mathrm{mg} / \mathrm{L}$ upstream from the Westborough wastewater-discharge point (fig. 27A), but only to about $3.5 \mathrm{mg} / \mathrm{L}$ at the downstream School Street site (fig. 27B; the increase in DO concentration at the School Street site was a result of the chamber falling over between the November 6 and 7 sample collections. After the chamber was righted, the DO resumed its decrease in concentration).

During the final round of sampling from June 6-12, 2008, concentrations of orthophosphorus in the pore water and inside the chamber upstream from the Westborough wastewater-discharge point increased after anoxic conditions developed (fig. 28A). At School Street during this period, DO concentrations declined but did not reach near-zero levels, and no consistent increases in concentrations were observed (fig. 28B). During chamber deployment, it was noted that the sediment quality at the sampling location upstream from the Westborough wastewater-discharge point had changed since the November 2007 assessments were made: more organic matter covered the surface. Decay of this organic matter isolated in the chamber likely created an increased SOD that depleted DO. Reduction of iron in oxyhydroxides at the sediment surface could also have contributed to DO depletion.

\section{Total Phosphorus and Orthophosphorus Flux Rates from Sediment in Free-Flowing Reaches}

For each chamber deployment, sediment-phosphorus flux rates for TP and orthoP were calculated. The difference in phosphorus concentration in the chamber between two consecutive samples in milligrams per liter was multiplied by the chamber's volume in liters and divided by the chamber's area in square meters to yield the change in phosphorus mass per square meter. This value was divided by the time between samplings in days to yield the flux rate in milligrams of phosphorus per square meter per day.
At the free-flowing sites, flux rates did not demonstrate any particular temporal or seasonal pattern (table 4). Overall, flux rates for both TP and orthoP were highest in June 2008 and were associated with the site upstream from the Westborough wastewater-discharge point and the downstream site at School Street in Northborough. These rates were substantially higher than those determined in July and November 2007 at the same sites. In the period between the November 2007 and June 2008 sample collections, the surficial sediment quality was observed to have changed from primarily sandy to primarily organic. This change in substrate could account for an increased rate of oxygen consumption and phosphorus release. Additional factors likely affected the relatively high values in June 2008 at the sampling site upstream from the wastewaterdischarge point and at the School Street sampling site: first, the duration of the June 2008 study was longer than the previous studies, allowing more time for DO depletion; second, the water temperatures in June 2008 were slightly higher than they were during the studies in July and August 2007 and substantially higher than those in November 2007, possibly affecting reaction rates. A substantial proportion of the net TP flux rates during the first sampling round were negative, indicating that TP was lost from the surface water in the chamber to the sediment. Net losses of TP at some sites - in Maynard, in particular - may be associated with settling of particles, a sandy substrate, an absence of the sufficiently low DO conditions needed to initiate sediment release, microbial uptake, or sorption. The relatively short duration of these initial studies in July 2007 (several hours) probably matched the settling time for the TP particles. Because it is in solution, orthoP would not be subject to settling unless it became bound to particulate material. As a result, relatively few negative orthoP flux values appear in the results.

\section{Total Phosphorus and Orthophosphorus Concentrations in Impounded Reaches}

Several sites in the two largest impoundments, Hudson and Ben Smith, were selected for investigation (fig. 29). During the first round of sediment-phosphorus flux sampling, three sites were monitored in each impoundment. In following rounds, only two sites were sampled in each impoundment.

During the first round of sampling at the Hudson impoundment, from July 25 to 26, 2007, samples were collected twice each day; at the Ben Smith impoundment, from August 21 to 23, 2007, samples were collected once each day for three days. At the Hudson impoundment, DO concentrations in the two chambers at sites $20^{3}$ and 29 (figs. 29B, C) declined to about $0 \mathrm{mg} / \mathrm{L}$, whereas at the third (site 17; fig. 29A), the DO concentration dropped to about $4.5 \mathrm{mg} / \mathrm{L}$

\footnotetext{
${ }^{3}$ Site numbers and their locations in the Hudson and Ben Smith impoundments are the same as previously used in Zimmerman and Sorenson (2005); the Hudson impoundment site numbers were those used in the phosphorus dynamics part of the study, and the Ben Smith site numbers were used to identify sediment-sampling sites.
} 


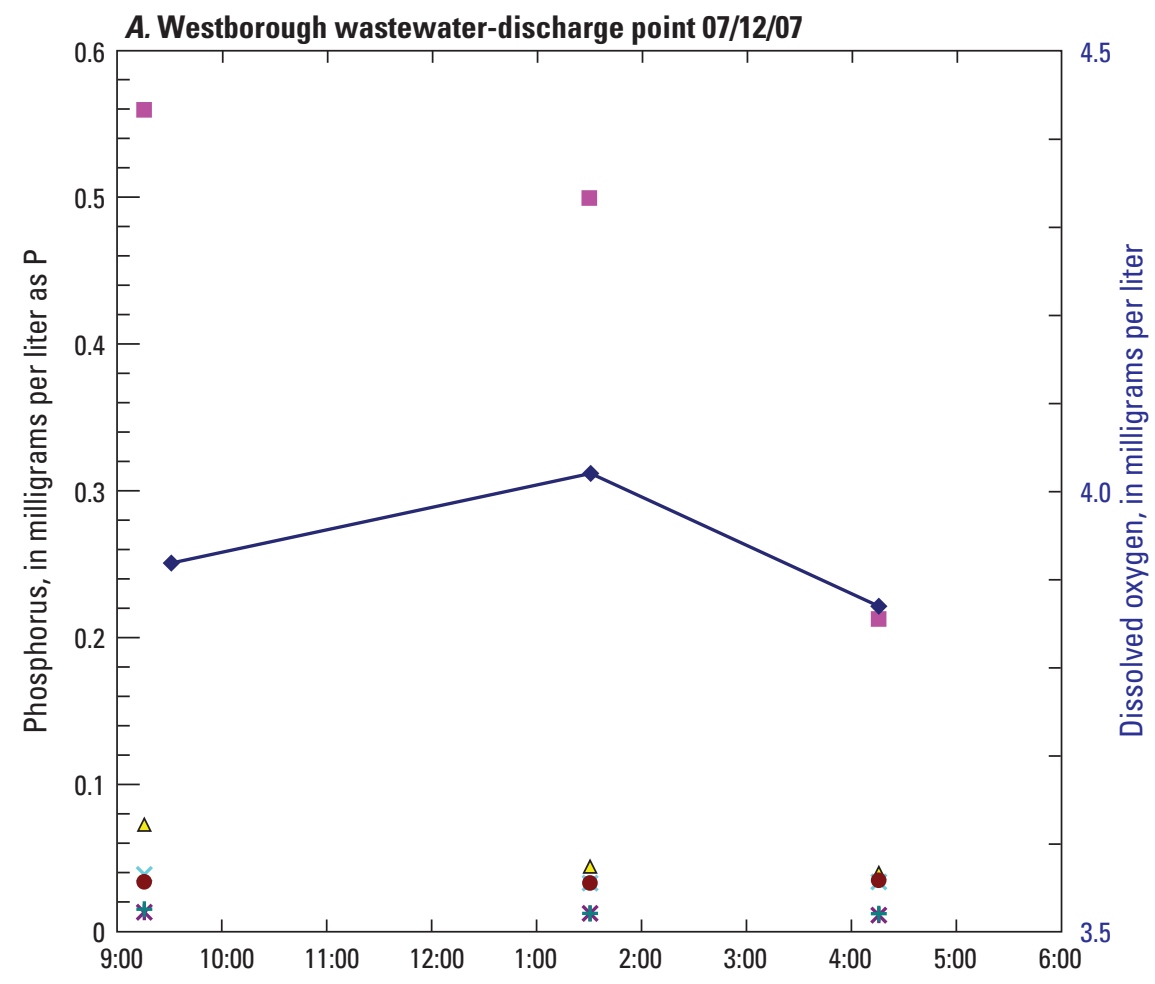

EXPLANATION

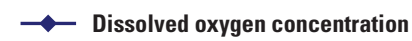

- Total phosphorus in pore water

$\Delta \quad$ Orthophosphorus in pore water

$\times$ Total phosphorus inside chamber

* Orthophosphorus inside chamber

- Total phosphorus outside chamber

+ Orthophosphorus outside chamber

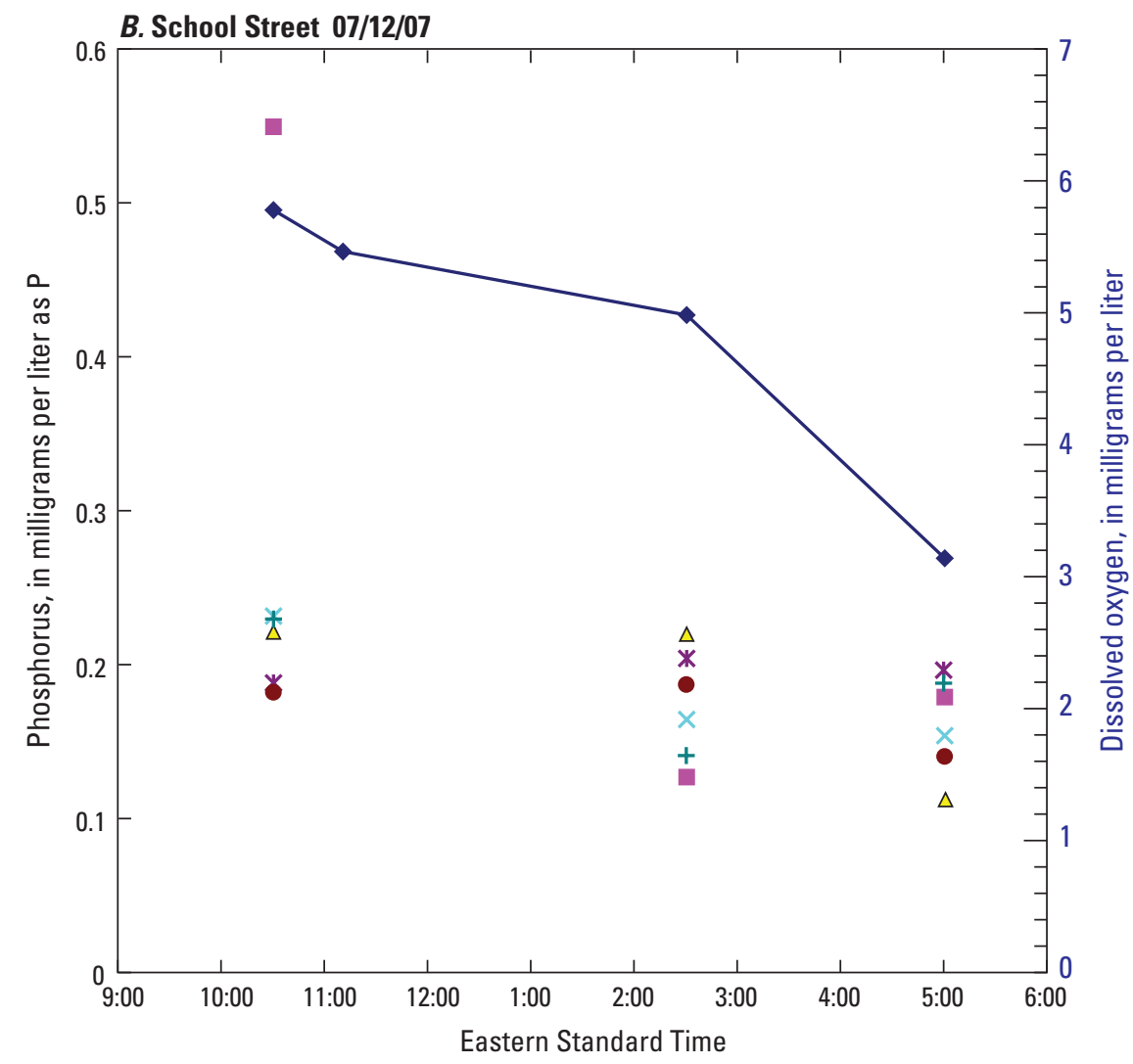

Figure 26. Phosphorus and dissolved oxygen concentrations measured in the first round of sediment-phosphorus flux sampling in five free-flowing reaches in the Assabet River study area in 2007: $A$, Westborough wastewater-discharge point; $B$, School Street and $C$, Robin Hill Road in Northborough; $D$, Cox Street in Hudson; and $E$ and $F$, Elks Club in Maynard. At the School Street site, pore-water orthoP concentrations exceeded TP concentrations in one sample, possibly because an alternate analytical method with a higher analytical range was used (Kathleen M. Bryant, U.S. Geological Survey, written commun., 2010). 

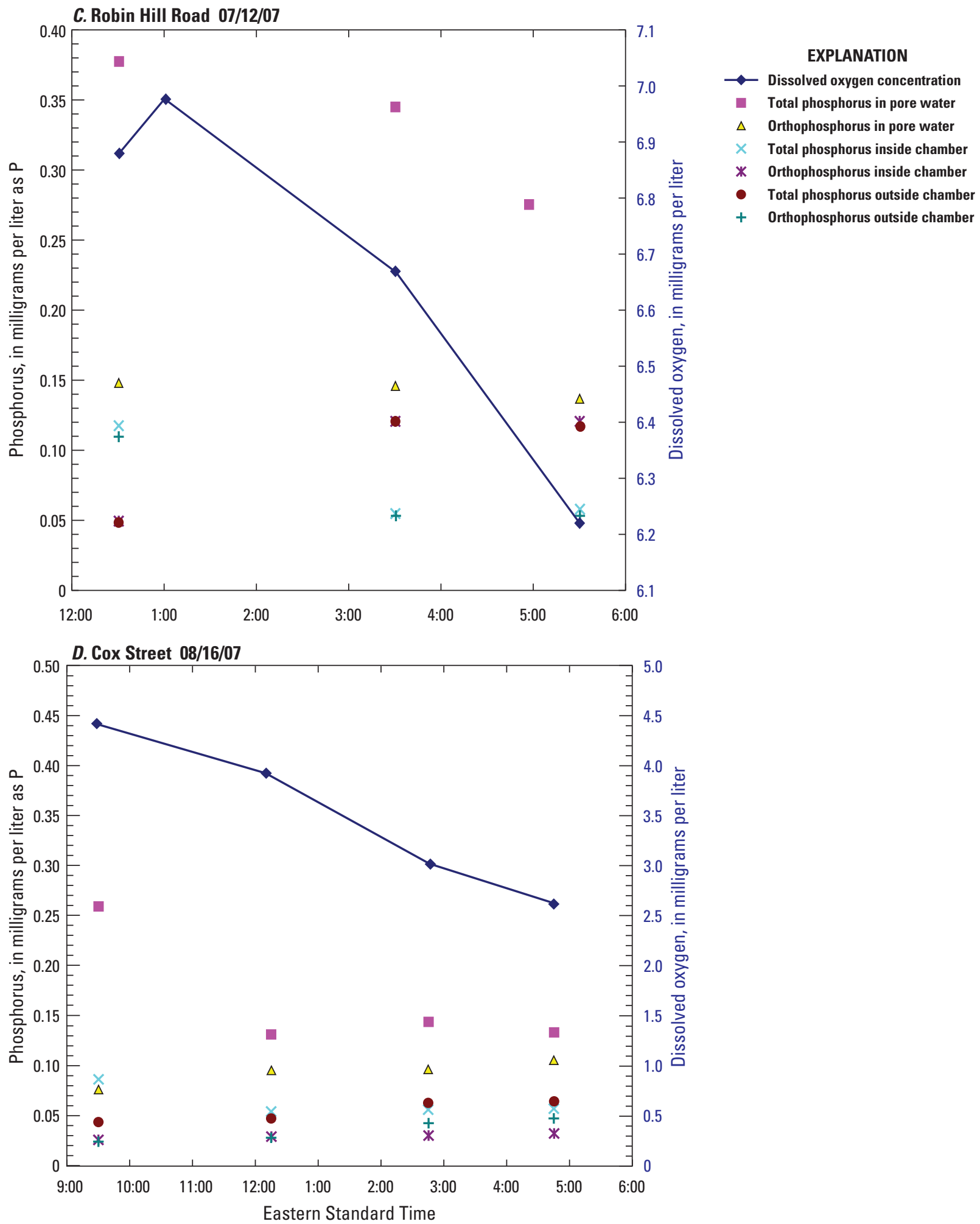

Figure 26.-Continued. 

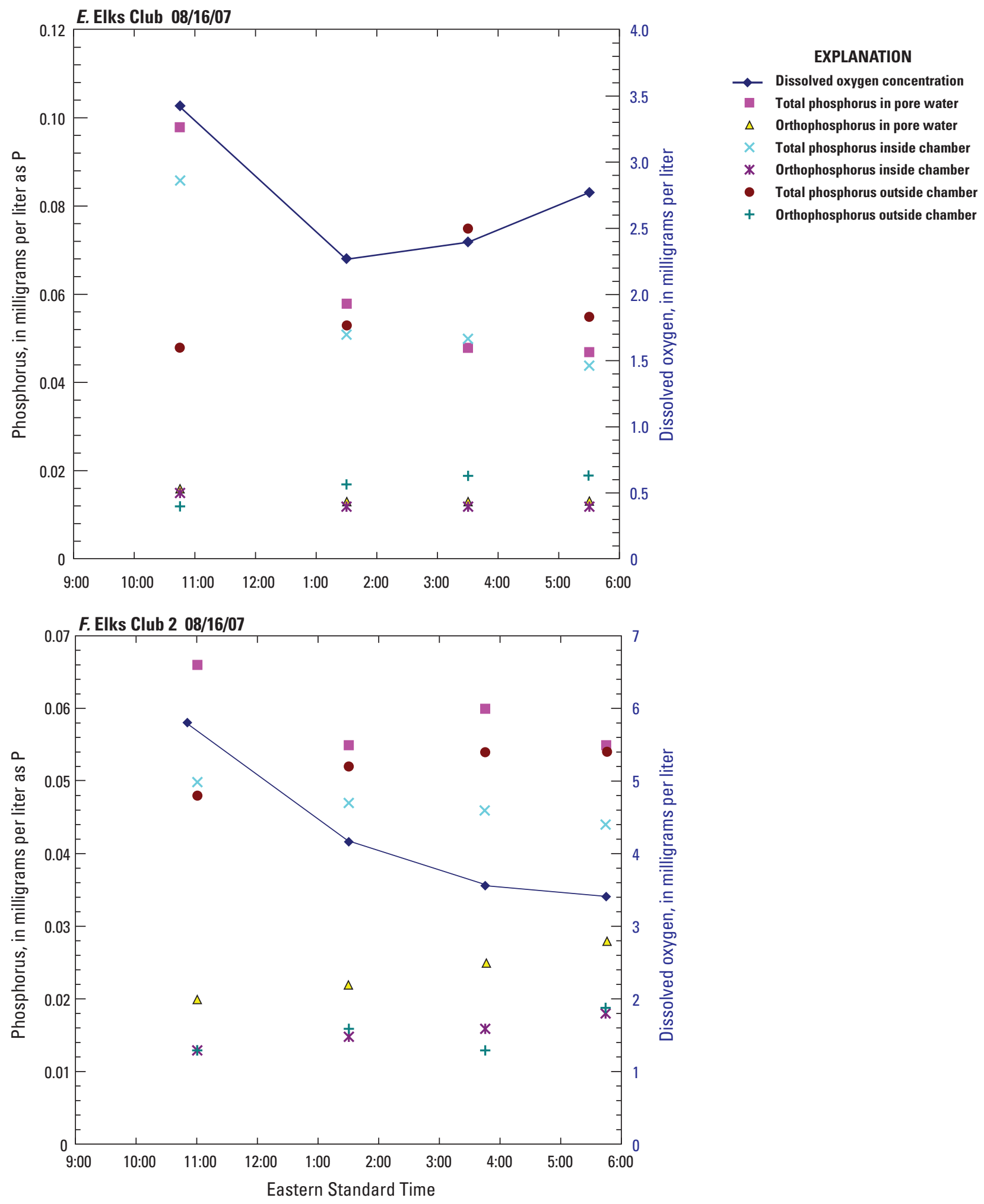

Figure 26.-Continued. 

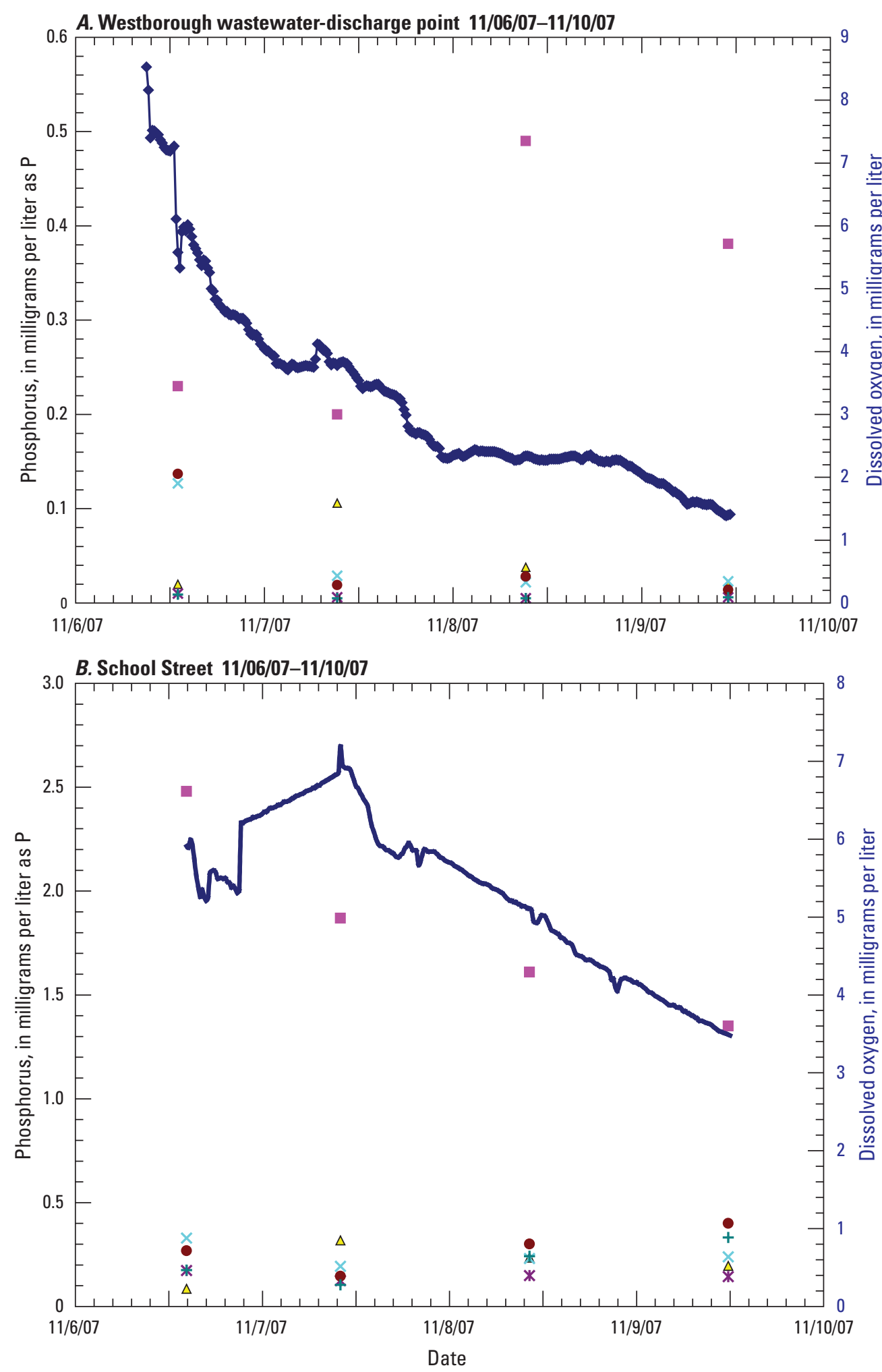

Figure 27. Phosphorus and dissolved oxygen concentrations measured in the second round of sediment-phosphorus flux sampling in two free-flowing reaches in the Assabet River study area in 2007: $A$, Westborough wastewater-discharge point; and $B$, School Street, Northborough. 

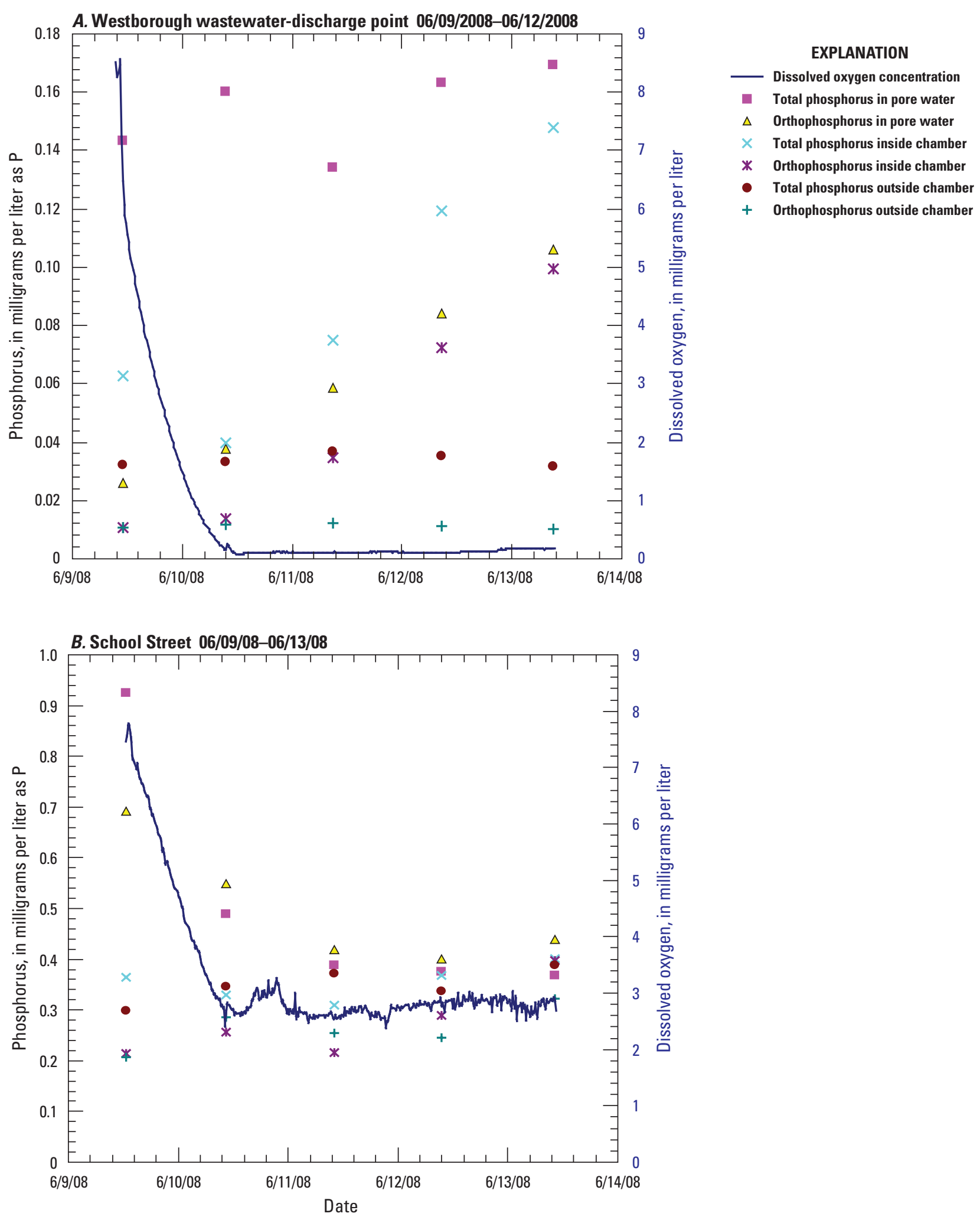

Figure 28. Phosphorus and dissolved oxygen concentrations measured in the third round of sediment-phosphorus flux sampling in two free-flowing reaches in the Assabet River study area in 2008: $A$, Westborough wastewater-discharge point; and $B$, School Street, Northborough. At the School Street site, pore-water orthoP concentrations exceeded TP concentrations in several samples, possibly because an alternate analytical method with a higher analytical range was used (Kathleen M. Bryant, U.S. Geological Survey, written commun., 2010). 
Table 4. Rates of change in concentrations of total phosphorus and orthophosphorus sampled inside flux chambers in free-flowing reaches in the study area.

[Values are derived from differences in phosphorus concentrations between consecutive samples. A negative flux rate indicates a decrease in phosphorus concentration. The shaded area indicates low dissolved oxygen concentrations in the chamber. WDP, near wastewater discharge point]

\begin{tabular}{|c|c|c|c|}
\hline \multirow{2}{*}{ Sampling site } & \multirow{2}{*}{$\begin{array}{l}\text { Sampling period } \\
\text { (month/day/year) }\end{array}$} & \multicolumn{2}{|c|}{ Flux rate (milligrams of phosphorus per square meter per day) } \\
\hline & & Total phosphorus & Orthophosphorus \\
\hline \multicolumn{4}{|c|}{ First sampling round } \\
\hline School Street, Northborough & 07/12/2007 & -24.0 & -19.6 \\
\hline Robin Hill Road, Marlborough & $07 / 12 / 2007$ & 0 & -7.90 \\
\hline Cox Street, Hudson & 08/16/2007 & 4.96 & 4.96 \\
\hline Elks Club \#1, Maynard & 08/16/2007 & -2.72 & 0 \\
\hline Elks Club \#1, Maynard & 08/16/2007 & -15.7 & 0 \\
\hline Elks Club \#2, Maynard & $08 / 16 / 2007$ & -2.42 & 2.42 \\
\hline Elks Club \#2, Maynard & $08 / 16 / 2007$ & -5.45 & 5.45 \\
\hline School Street, Northborough & $11 / 8-9 / 2007$ & 1.8 & -1.13 \\
\hline \multicolumn{4}{|c|}{ Third sampling round } \\
\hline Westborough WDP, Westborough & $06 / 10-11 / 2008$ & 8.16 & 4.88 \\
\hline Westborough WDP, Westborough & $06 / 11-12 / 2008$ & 10.2 & 8.66 \\
\hline Westborough WDP, Westborough & $06 / 12-13 / 2008$ & 6.38 & 6.07 \\
\hline School Street, Northborough & $06 / 10-11 / 2008$ & -4.62 & -9.830 \\
\hline School Street, Northborough & $06 / 11-12 / 2008$ & 14.2 & 18.0 \\
\hline School Street, Northborough & $06 / 12-13 / 2008$ & 7.62 & 25.1 \\
\hline
\end{tabular}

on July 25 and did not change thereafter. It is possible that the sediment at site 17 consisted primarily of sand, which would have allowed aerated surface water to circulate into the bottom of the chamber. Another less likely possibility is that an undetected submerged object wedged under the chamber may have allowed ambient water to enter and would thus also account for the stable DO concentrations and for the relatively small changes in TP and orthoP concentrations inside the chamber. In contrast, at Hudson sites 20 and 29 and at the three sites in the Ben Smith impoundment (figs. 29D-F), DO concentrations dropped to nearly $0 \mathrm{mg} / \mathrm{L}$ during the sampling periods. After near-anaerobic conditions were reached, increases were detected in TP and orthoP in the chambers; when DO concentrations were closer to $0, \mathrm{TP}$ and orthoP concentrations occasionally exceeded the concentrations in the pore water. In general, and particularly when DO concentrations were not close to 0 , TP and orthoP concentrations in the pore water were greater than in the chamber or in the ambient water.

When the first samples were collected during the second (late-fall) sampling round at the Hudson and Ben Smith impoundments, initial DO concentrations were generally higher than during other parts of the study's field work (fig. 30); water temperatures were lower in the late fall than at other times, and this condition increases the saturation concentration. The two relatively high initial DO concentrations (greater than $12 \mathrm{mg} / \mathrm{L}$ ) measured during summer sampling in 2007 were probably a result of supersaturation caused by photosynthesis. DO concentrations inside the chambers fell to near zero during the sampling period at all of the sites (figs. 30A-C), with the exception of Ben Smith site 41 (fig. 30D); it is possible that the chamber at site 41 did not deploy properly, allowing DO to enter the chamber. At Hudson site 29 (fig. 30B), the DO concentration dropped 


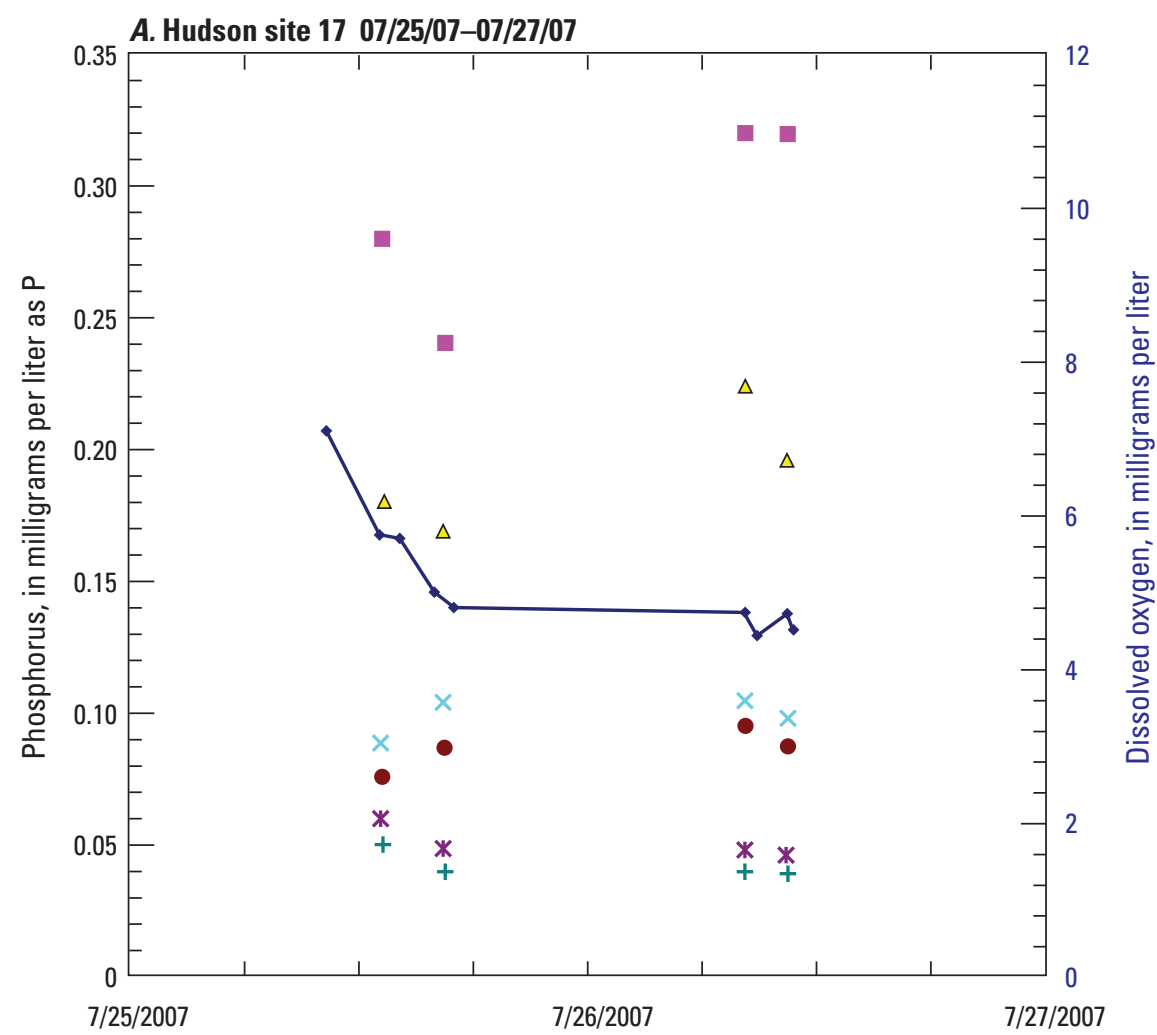

EXPLANATION

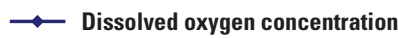

- Total phosphorus in pore water

$\Delta \quad$ Orthophosphorus in pore water

- Total phosphorus inside chamber

* Orthophosphorus inside chamber

- Total phosphorus outside chamber

+ Orthophosphorus outside chamber

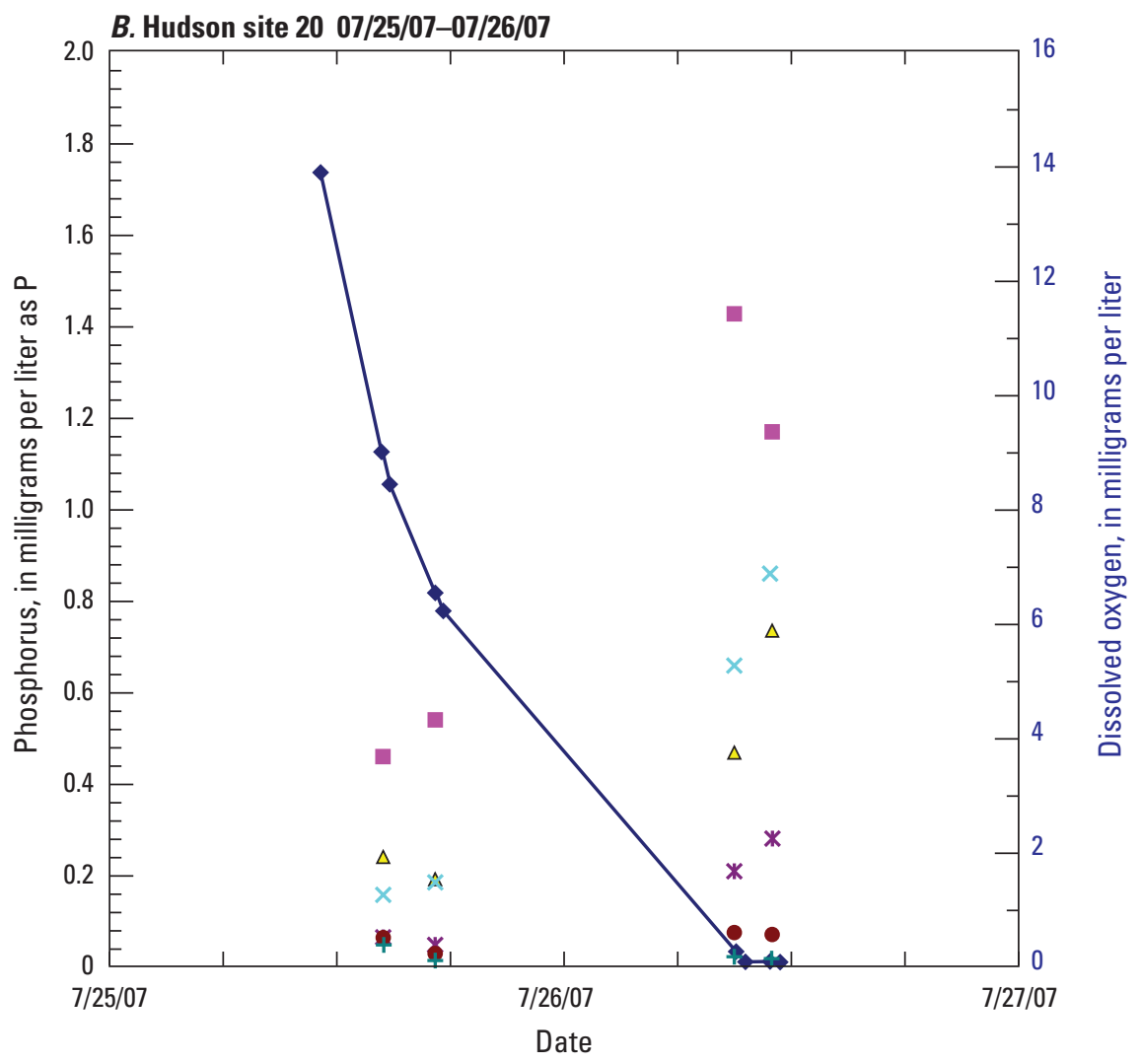

Figure 29. Phosphorus and dissolved oxygen concentrations measured in the first round of sediment-phosphorus flux sampling in six impounded reaches in the Assabet River study area in 2007: $A$, Hudson site 17; $B$, Hudson site 20; $C$, Hudson site 29; $D$, Ben Smith site 32; $E$, Ben Smith site 38; and F, Ben Smith site 41. 


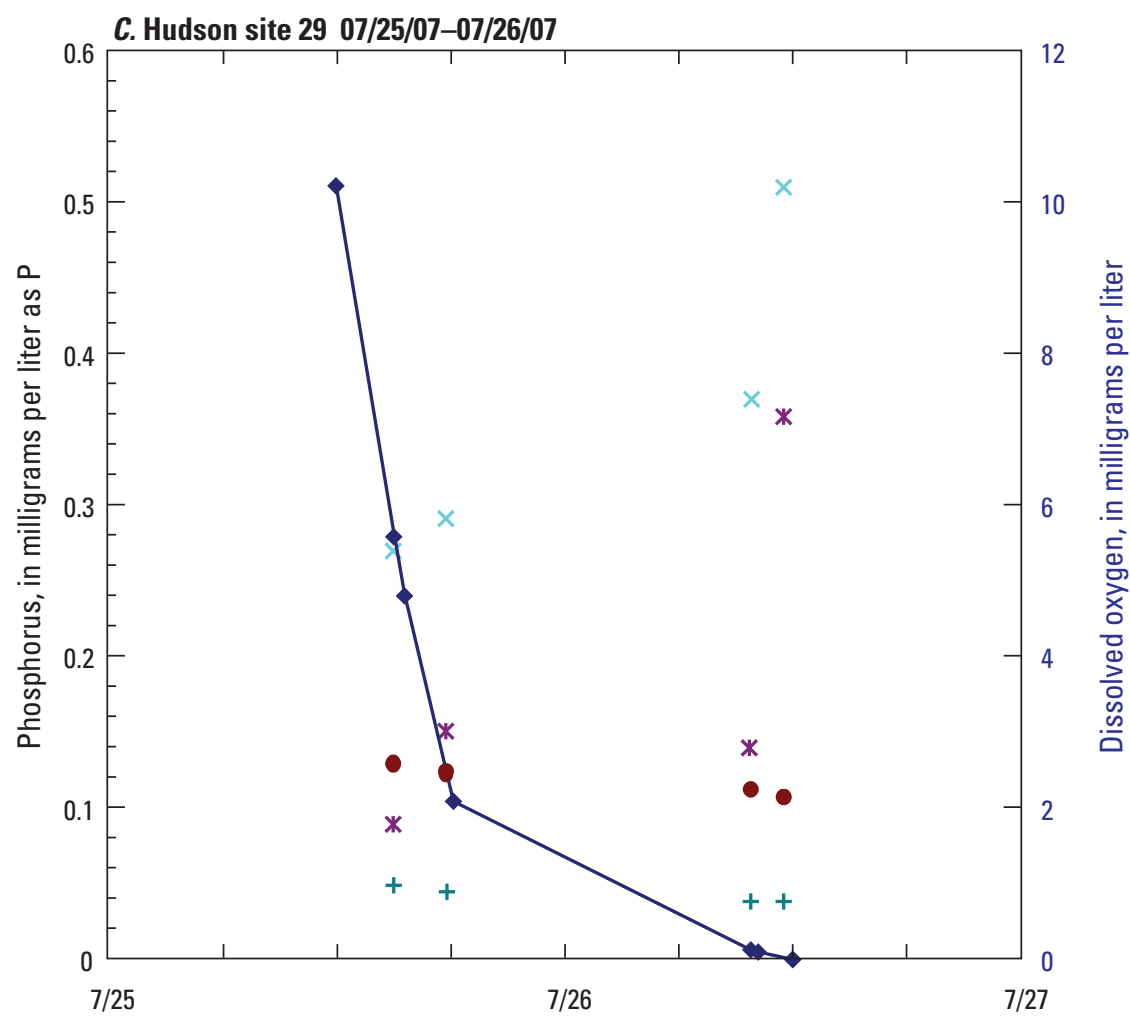

EXPLANATION

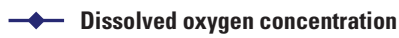

- Total phosphorus in pore water

$\Delta \quad$ Orthophosphorus in pore water

$\times$ Total phosphorus inside chamber

* Orthophosphorus inside chamber

- Total phosphorus outside chamber

+ Orthophosphorus outside chamber

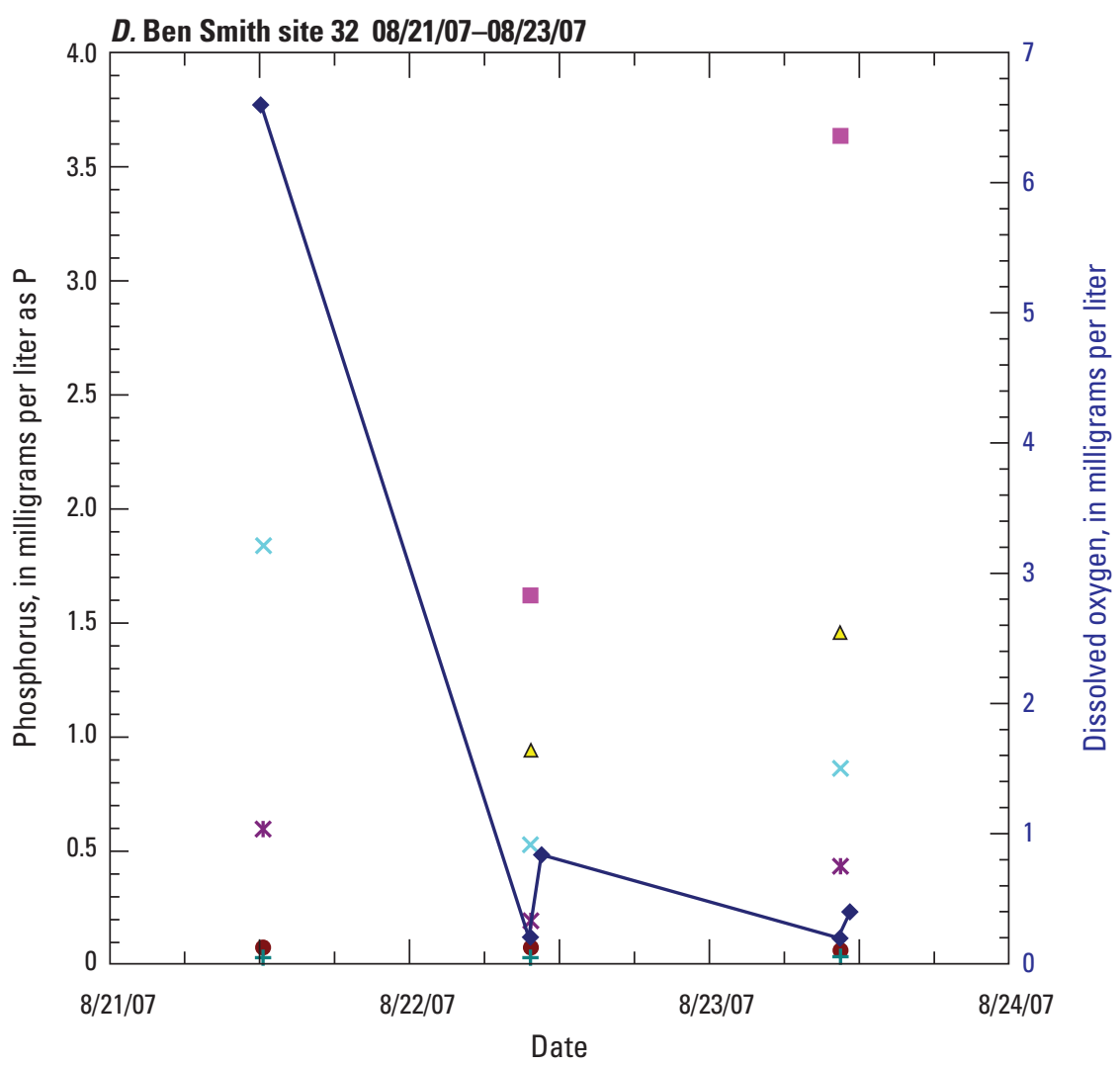

Figure 29.-Continued. 

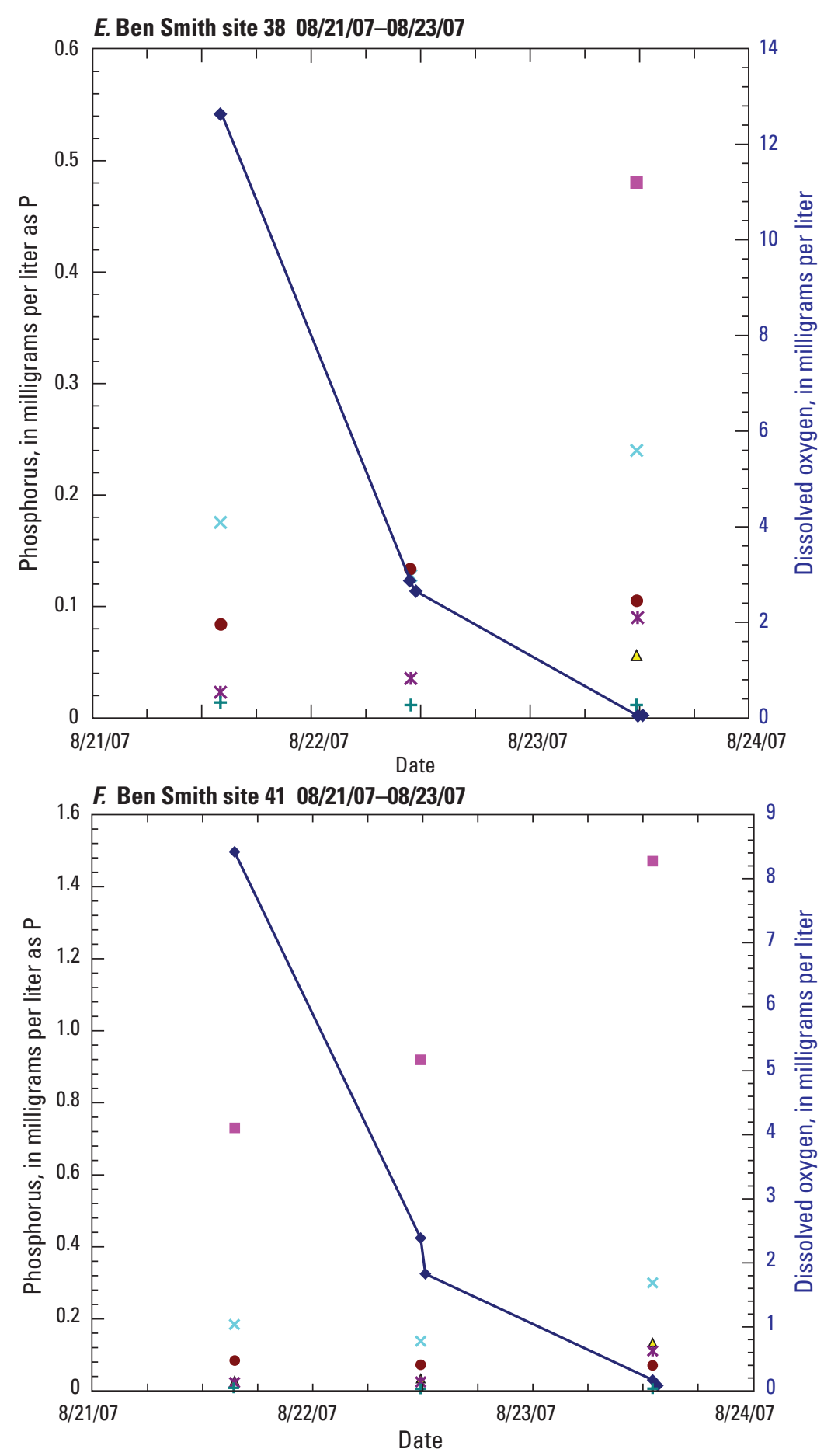

Figure 29.-Continued. 


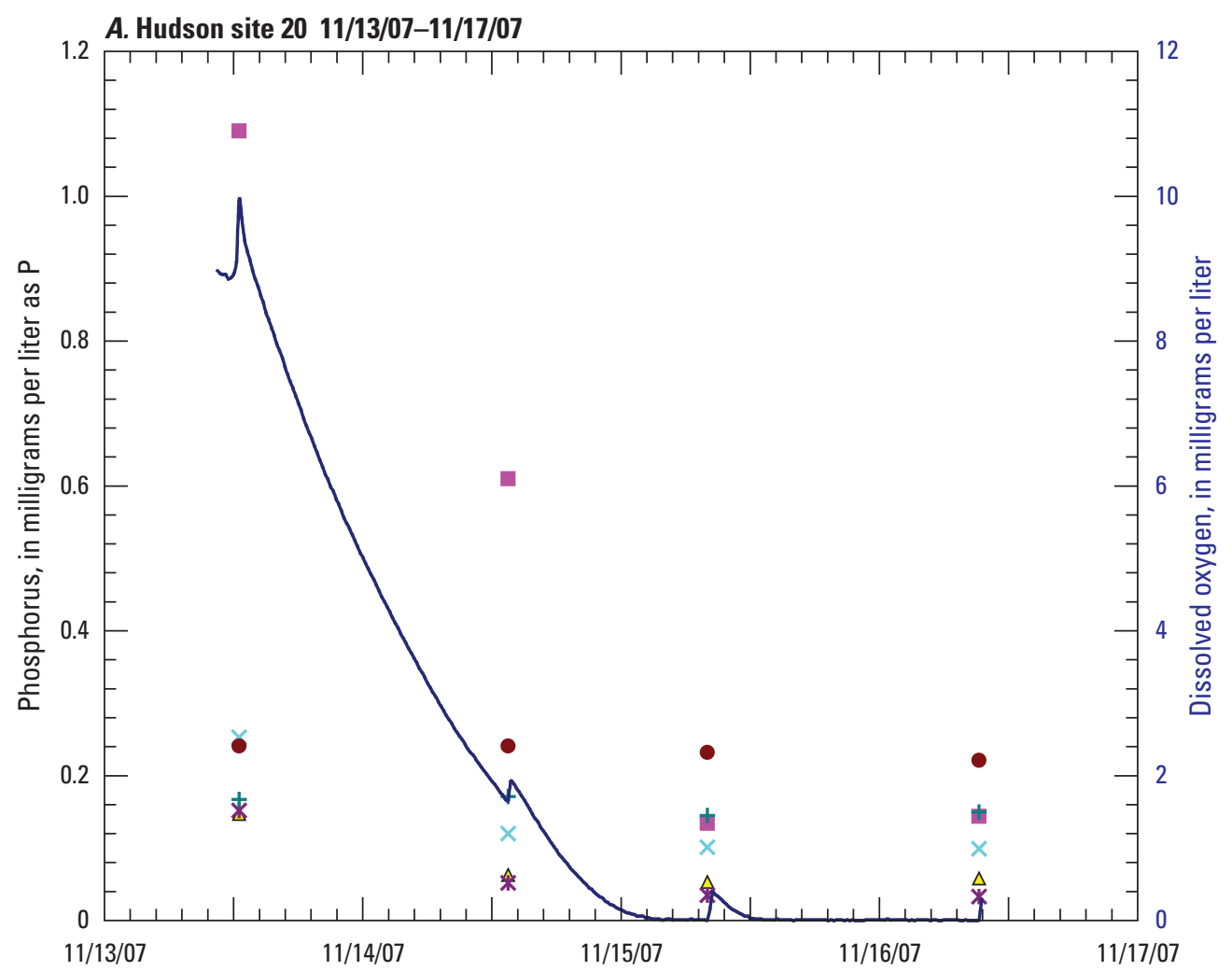

EXPLANATION

Dissolved oxygen concentration

Total phosphorus in pore water

$\Delta \quad$ Orthophosphorus in pore water

$\times$ Total phosphorus inside chamber

* Orthophosphorus inside chamber

- Total phosphorus outside chamber

+ Orthophosphorus outside chamber

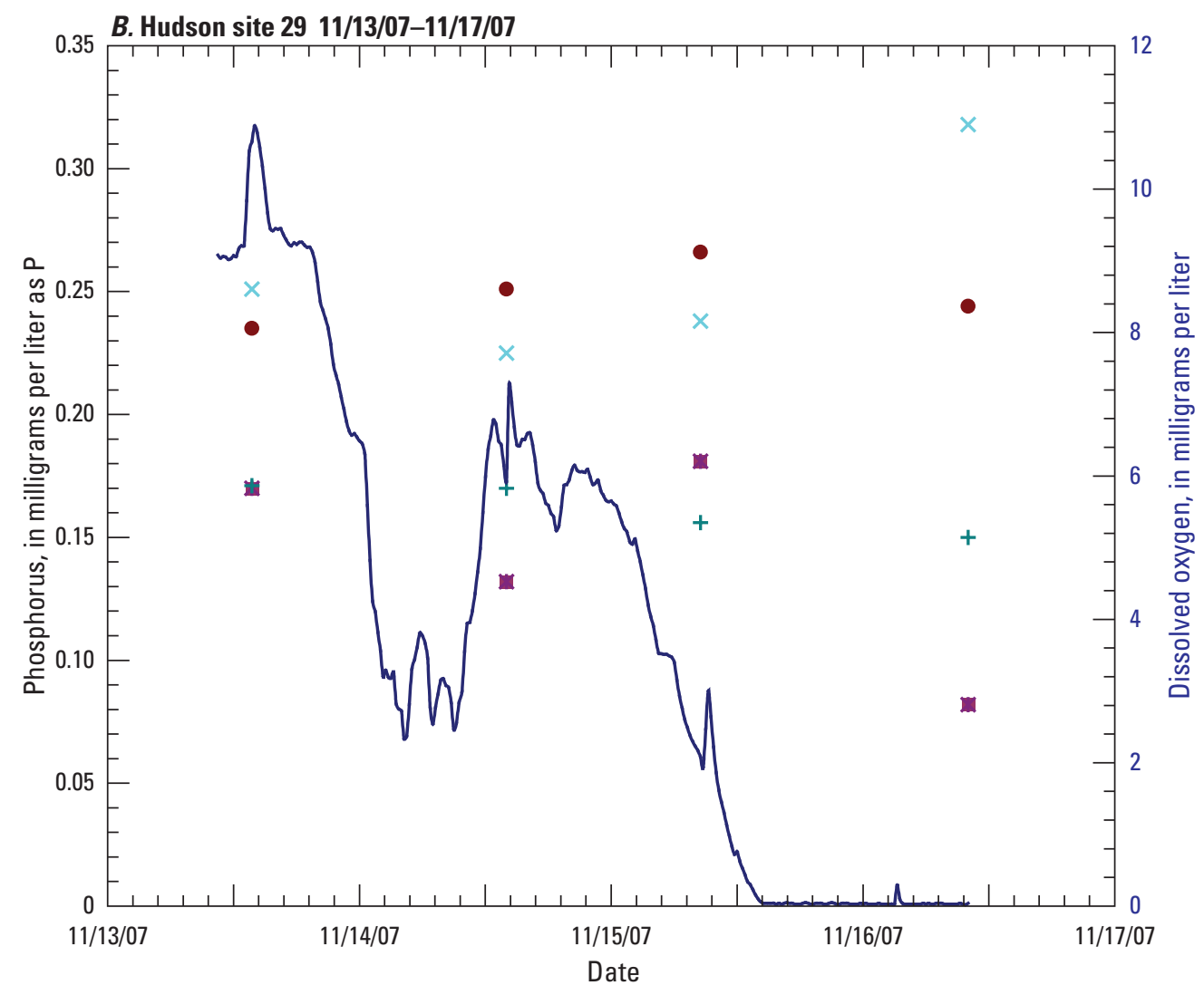

Figure 30. Phosphorus and dissolved oxygen concentrations measured in the second round of sediment-phosphorus flux sampling in four impounded reaches in the Assabet River study area in 2007: A, Hudson site 20; $B$, Hudson site 29; $C$, Ben Smith site 32; and $D$, Ben Smith site 41 . 


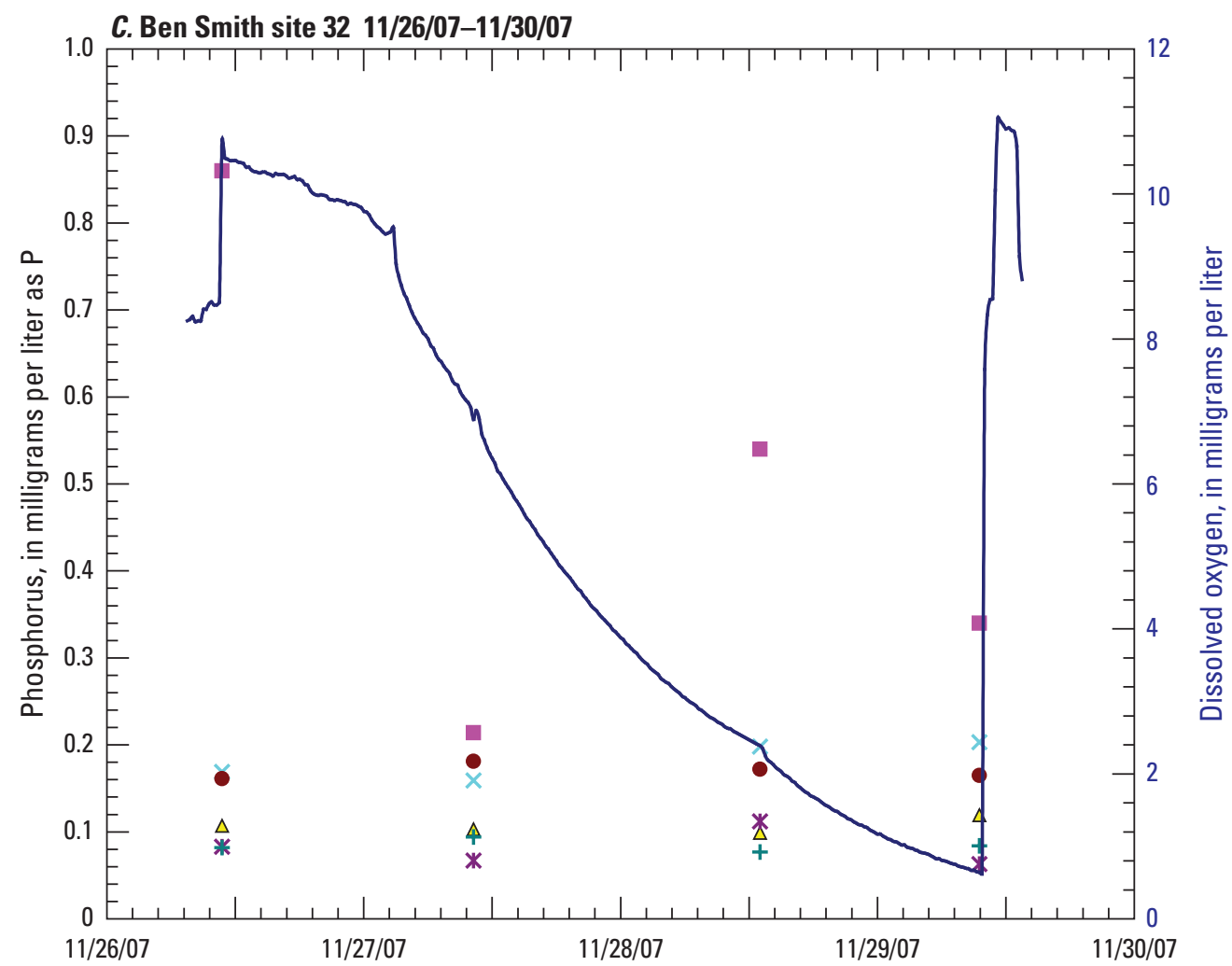

\section{EXPLANATION}

Dissolved oxygen concentration

Total phosphorus in pore water

$\Delta \quad$ Orthophosphorus in pore water

$\times$ Total phosphorus inside chamber

* Orthophosphorus inside chamber

- Total phosphorus outside chamber

+ Orthophosphorus outside chamber

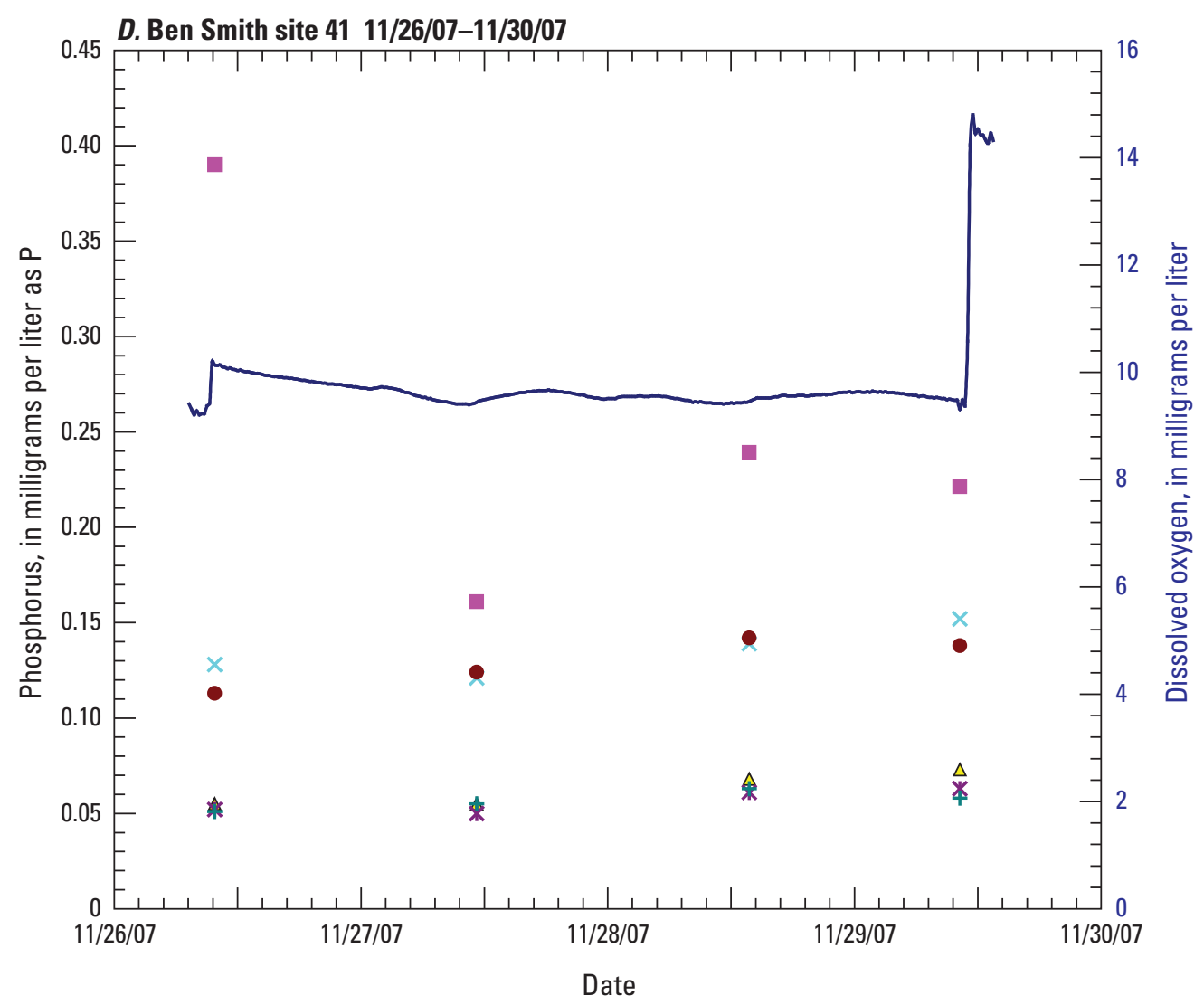

Figure 30.-Continued. 
at first, and then rose briefly on November 14 before falling again; this fluctuation may have been caused by a physical disturbance during the sampling process. During the sampling period, no systematic increases were observed in any of the TP or orthoP concentrations in the pore water, inside the chamber, or in the ambient water. Water temperatures were no greater than $5.4^{\circ} \mathrm{C}$ in November, whereas they exceeded $20^{\circ} \mathrm{C}$ for the other samples. These results indicate that, in addition to the relation to DO concentrations, there is a temperature component to sediment-phosphorus flux in the Assabet River system that probably has diffusion-rate and biological-process components.

During the final round of sampling in June 2008, samples from the pore water in the Hudson impoundment could be retrieved only at site 20 (fig. 31A). The clayey sediments at the other sites in the Hudson and Ben Smith impoundments clogged the screens, preventing water from entering the SedPoints. That pore water could be collected on previous sampling dates demonstrates the areal heterogeneity of the river sediments, even among samples collected no more than a few meters apart. At all sites, except Hudson site 29 (fig. 31B), DO concentrations dropped to less than $1 \mathrm{mg} / \mathrm{L}$ (figs. 31 A, C, and D). In spite of DO concentrations higher than 0 at Hudson site 29 (fig. 31B) and Ben Smith site 32 (fig. 31C), TP and orthoP generally increased over time after the DO minimum was reached at each site. The same sonde was used at Hudson site 29 and Ben Smith site 32, and it may have had an undiagnosed problem that could have affected DO readings. The results of previous studies at these two sites indicate that the sonde DO data were incorrect, and that the DO concentrations were actually close to $0 \mathrm{mg} / \mathrm{L}$.

\section{Total Phosphorus and Orthophosphorus Flux Rates from Sediment in Impounded Reaches}

Rates of phosphorus release were, for the most part, greater in the warm months of July and August 2007 and June 2008 than in November 2007 (table 5). Warm temperatures would be more conducive to increased SOD that would drive down the DO concentrations, facilitate the disruption of the sediment-water interface by reducing ferric oxyhydroxides, and allow phosphorus to diffuse from the sediment pore water into the chamber. In July 2007, the highest TP flux rate, 514 milligrams per square meter per day $\left(\mathrm{mg} / \mathrm{m}^{2} / \mathrm{d}\right)$, and the highest orthoP flux rate, $396 \mathrm{mg} / \mathrm{m}^{2} / \mathrm{d}$, were determined from data for sites 20 and 29, respectively, in the Hudson impoundment. The highest sequestration rate for TP, $-8.65 \mathrm{mg} / \mathrm{m}^{2} / \mathrm{d}$, was measured at Hudson site 17 in July 2007, and the highest sequestration rate for orthoP, $-18.8, \mathrm{mg} / \mathrm{m}^{2} / \mathrm{d}$, was measured at Hudson site 29 in November 2007 (table 5).

\section{Comparison of Sediment-Phosphorus Flux Rates between Free-Flowing and Impounded Reaches}

In general, the flux rates from sediments in free-flowing reaches of the river were smaller than the flux rates from impounded reaches (tables 4 and 5). Sequestration was more common in the free-flowing reaches than in the impounded reaches. Similar to rates in the impounded reaches, the rates in the free-flowing reaches were smallest during the second round of sampling in November 2007, when water temperatures were lowest and DO concentrations inside the chambers decreased the least. Knowledge of seasonal and hydrological conditions may help regulators to identify the conditions that are likely to produce a 90-percent reduction in phosphorus flux rates as required by the TMDL.

\section{Comparison of Results of USGS Studies with Results of ENSR International and CDM Laboratory Studies}

ENSR International used sediment-phosphorus flux rates of 21.6 and $12.0 \mathrm{mg} \mathrm{P} / \mathrm{m}^{2} /$ day in downstream and upstream sections of the river, respectively, in its computer simulations (David Pincumbe, U.S. Environmental Protection Agency, written commun., 2009). Regardless of the fact that the same flux rates were respectively assigned to all reaches within the upstream and downstream sections, both sections include freeflowing and impounded reaches.

Taking into consideration the differences in methodologies used in the sediment-phosphorus-flux measurements, the flux rates used by ENSR International were reasonably comparable to the largest release rates determined in this study for free-flowing reaches (table 6); with the exception of the rates determined in the second (late fall) sampling round of this study, the ENSR International sediment-phosphorus flux rates were substantially less than the rates determined for the impounded reaches in this study. On the other hand, the rates used by ENSR International in the modeling study (ENSR International, 2005) were higher than determined in their laboratory studies.

The sediment-phosphorus release rates determined by CDM in its December 2006 studies of sediment-phosphorus flux from sediment cores taken from impounded reaches had wide ranges of values that, unlike the USGS results, did not exceed zero (table 6); the CDM-determined rates ranged from -156 (net sequestration rate) to $0 \mathrm{mg} \mathrm{P} / \mathrm{m}^{2}$ /day (no net flux of $\mathrm{P}$ into or out of sediment). In data derived from samples from cores collected at the free-flowing sites, the range of CDM sediment-phosphorus-flux rates exceeded the entire range, encompassing both sequestration and release, of sediment phosphorus-flux rates indicated by the USGS data (table 6). 

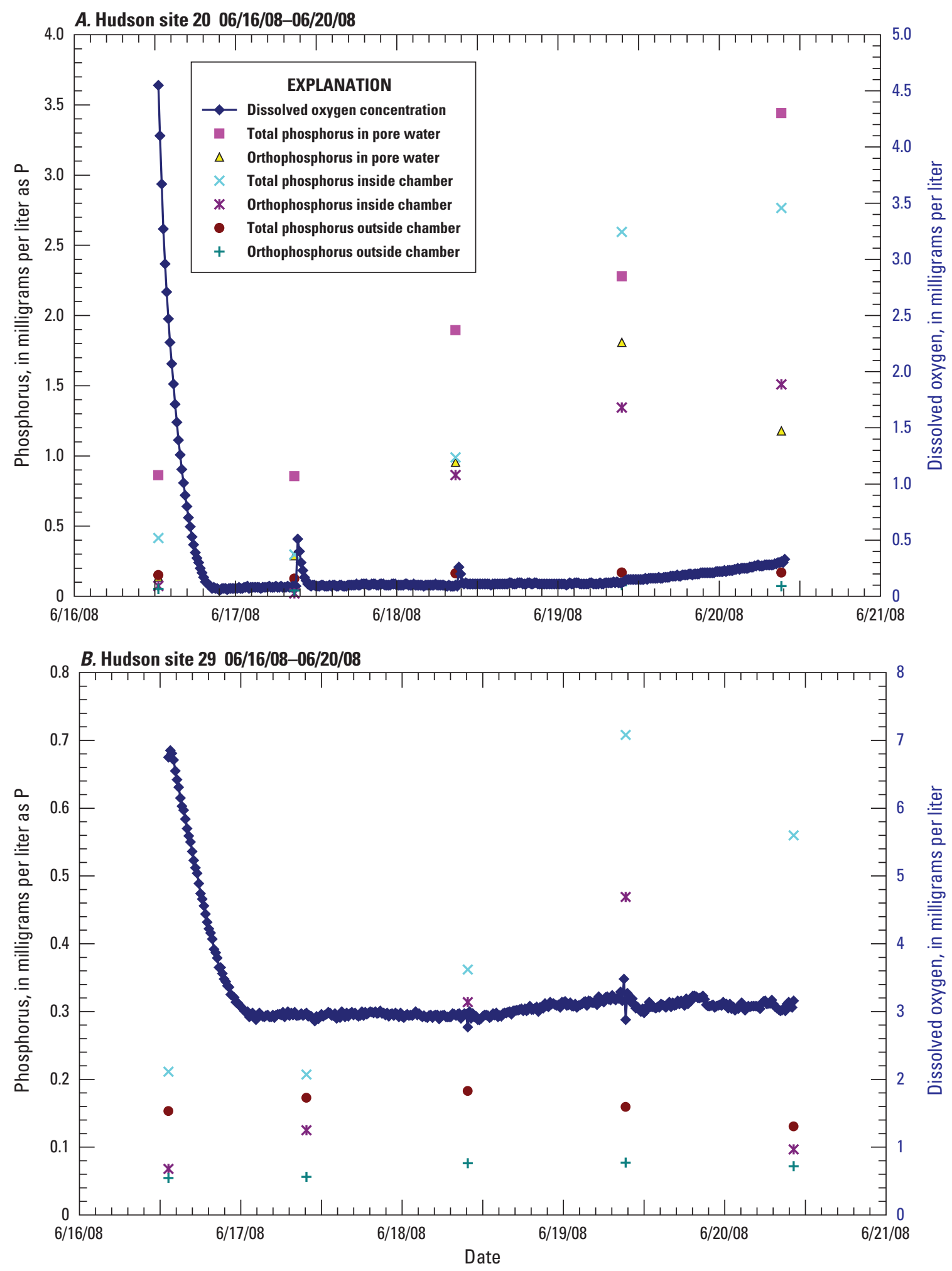

Figure 31. Phosphorus and dissolved oxygen concentrations measured in the third round of sedimentphosphorus flux sampling in four impounded reaches in the Assabet River study area in 2008: $A$, Hudson site 20; $B$, Hudson site 29; $C$, Ben Smith site 32; and D, Ben Smith site 41. 
C. Ben Smith site 32 06/23/08-06/27/08
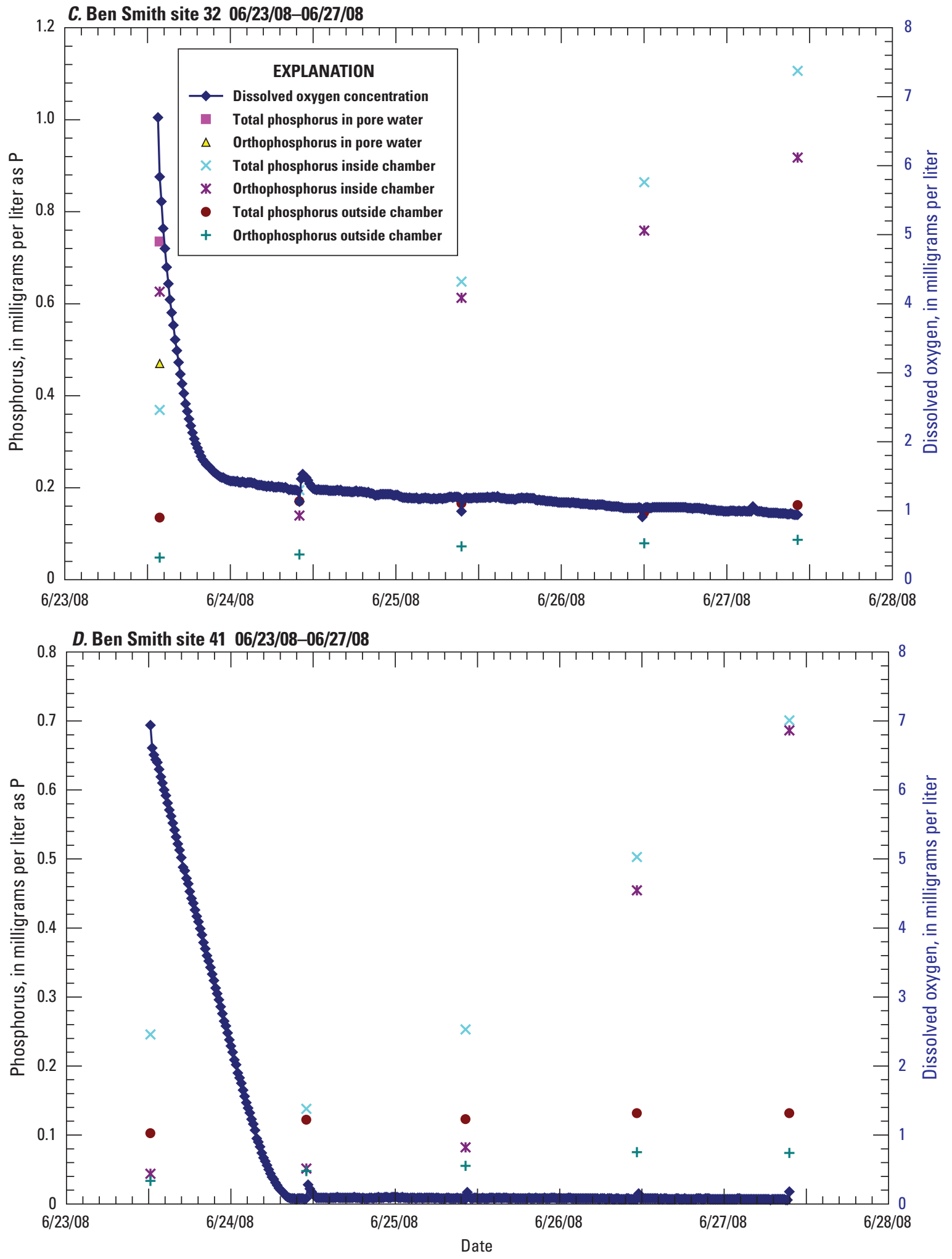

Figure 31.-Continued. 


\section{Monitoring Aquatic Macrophyte Biomass and Sediment-Phosphorus Flux, Assabet River, Massachusetts}

Table 5. Rates of change in concentrations of total phosphorus and orthophosphorus sampled inside flux chambers in impounded reaches in the study area.

[Values are derived from differences in phosphorus concentrations between consecutive samples. A negative flux rate indicates a decrease in phosphorus concentration. The shaded areas indicate low dissolved oxygen concentrations in the chamber]

\begin{tabular}{|c|c|c|c|}
\hline \multirow{2}{*}{ Sampling site } & \multirow{2}{*}{$\begin{array}{l}\text { Sampling period } \\
\text { (month/day/year) }\end{array}$} & \multicolumn{2}{|c|}{ Flux rate (milligrams of phosphorus per square meter per day } \\
\hline & & Total phosphorus & Orthophosphorus \\
\hline \multicolumn{4}{|c|}{ First sampling round } \\
\hline Hudson Site 17 & $07 / 25-26 / 2007$ & -8.65 & -3.46 \\
\hline Hudson Site 20 & $07 / 25-26 / 2007$ & 514 & 167 \\
\hline Hudson Site 29 & $07 / 25-26 / 2007$ & 253 & 396 \\
\hline Ben Smith 32 & $08 / 22-23 / 2007$ & 48.2 & 59.6 \\
\hline Ben Smith 38 & $08 / 22-23 / 2007$ & 21.9 & 10.4 \\
\hline Ben Smith 41 & $08 / 22-23 / 2007$ & 25.6 & 13.6 \\
\hline \multicolumn{4}{|c|}{ Second sampling round } \\
\hline Hudson Site 20 & $11 / 14-15 / 2007$ & -4.97 & -4.44 \\
\hline Hudson Site 20 & $11 / 15-16 / 2007$ & -0.383 & -0.383 \\
\hline Hudson Site 29 & $11 / 14-15 / 2007$ & 3.40 & 12.80 \\
\hline Hudson Site 29 & $11 / 15-16 / 2007$ & 15.2 & -18.8 \\
\hline Ben Smith 32 & $11 / 27-28 / 2007$ & 6.16 & 8.69 \\
\hline Ben Smith 32 & $11 / 28-29 / 2007$ & 1.03 & -10.1 \\
\hline Ben Smith 41 & $11 / 27-28 / 2007$ & 3.49 & 2.13 \\
\hline Ben Smith 41 & $11 / 28-29 / 2007$ & 3.26 & 0.502 \\
\hline \multicolumn{4}{|c|}{ Third sampling round } \\
\hline Hudson Site 20 & $06 / 17-18 / 2008$ & 122 & 148 \\
\hline Hudson Site 20 & 06/18-19/2008 & 274 & 82.30 \\
\hline Hudson Site 20 & 06/19-20/2008 & 30.4 & 29.4 \\
\hline Hudson Site 29 & $06 / 17-18 / 2008$ & 27.3 & 33.3 \\
\hline Hudson Site 29 & 06/18-19/2008 & 62.2 & 27.9 \\
\hline Ben Smith 32 & $6 / 24-25 / 2008$ & 81.6 & 85.2 \\
\hline Ben Smith 32 & $6 / 25-26 / 2008$ & 34.4 & 23.3 \\
\hline Ben Smith 32 & $6 / 26-27 / 2008$ & 46.0 & 30.2 \\
\hline Ben Smith 41 & $6 / 24-25 / 2008$ & 20.9 & 5.58 \\
\hline Ben Smith 41 & $6 / 25-26 / 2008$ & 42.3 & 63.0 \\
\hline Ben Smith 41 & $6 / 26-27 / 2008$ & 37.6 & 44.0 \\
\hline
\end{tabular}


Table 6. Comparisons among flux rates of sediment phosphorus in laboratory studies reported by ENSR International and Camp Dresser \& McKee, Inc., and determined in field studies by the U.S. Geological Survey.

[All values are in units of milligrams per square meter per day; negative values indicate flux into the sediment. USGS, U.S. Geological Survey; CDM, Camp Dresser \& McKee, Inc.]

\begin{tabular}{|c|c|c|}
\hline & ENSR & USGS \\
\hline Maximum, total phosphorus & 13.3 & 514 \\
\hline Minimum, total phosphorus & -1.7 & -24.0 \\
\hline Maximum, orthophosphorus & 8.3 & 396 \\
\hline \multirow[t]{2}{*}{ Minimum, orthophosphorus } & -2.1 & -19.6 \\
\hline & CDM & USGS \\
\hline Impounded sites, total phosphorus & -156 to 0 & -8.65 to 514 \\
\hline $\begin{array}{l}\text { Riverine (free-flowing) sites, total } \\
\text { phosphorus }\end{array}$ & -87 to 35 & -24.0 to 14.2 \\
\hline
\end{tabular}

Attempts to apply the data out of context could result in conflicting modeling results. Given that the samples were collected at different times and locations, that the experimental systems were manipulated in a variety of different ways, that the results were within about two orders of magnitude, and that the cool-weather fluxes were generally from the water column to the sediment, the results of the two studies are generally consistent with one another. Moreover, that sediment fluxes to the water column were measured in the sedimentcore and chamber studies only under extremely low-DO to anaerobic conditions rarely, if ever, found in the Assabet River impoundments suggests that sediment is not likely to be a major phosphorus source, especially when phosphorus concentrations from sediments are compared to the ambient concentrations sustained by wastewater effluent.

\section{Summary and Conclusions}

The Assabet River Phosphorus Total Maximum Daily Load, approved by the U.S. Environmental Protection Agency in 2004, prescribed reductions in phosphorus concentrations for wastewater-treatment plant discharges along the Assabet River. The eventual results of these reductions were to include (1) lower concentrations of total and dissolved phosphorus in the river; (2) a 50-percent reduction in aquatic-plant biomass; (3) a 30-percent reduction in instances of dissolved oxygen supersaturation; (4) no low-flow dissolved oxygen concentrations less than 5.0 milligrams per liter; and (5) and a 90-percent reduction in sediment releases of phosphorus to the overlying water. In 2007 and 2008, the U.S. Geological
Survey, in cooperation with the Massachusetts Department of Environmental Protection, undertook studies to monitor aquatic-plant distribution and biomass and the potential rates of phosphorus release from sediments in free-flowing and impounded reaches of the Assabet River prior to the reductions in phosphorus concentrations.

\section{Aquatic Macrophytes}

As a surrogate for the monitoring of all aquatic macrophytes, the U.S. Geological Survey developed and implemented a monitoring program for Lemna minor, commonly known as lesser duckweed. Lemna was monitored at eight selected locations in the five largest Assabet River impoundments, where it was known to accumulate. A trained observer estimated the Lemna coverage at each location on a weekly or biweekly basis. During the 2007 and 2008 growing seasons, hydrological conditions differed substantially; in 2007, although streamflows were somewhat greater than usual, Lemna accumulated heavily in most locations monitored; in 2008, streamflows were even higher than in 2007, and there were no heavy Lemna accumulations. At most of the locations monitored, estimated biomass in 2007 was approximately twice as great as in 2008. The effects of year-to-year variability in summer streamflow on estimated biomass and aesthetic impairment of the impoundments underscored the importance of maintaining long-term records to evaluate the effects of the implementation of phosphorus-reduction improvements.

In addition to the visual monitoring of Lemna, the use of satellite-based, multispectral, remote-sensing data was investigated as a potential nonsubjective means for assessing the extent of aquatic-plant growth. By comparing in situ hyperspectral data obtained by a field spectroradiometer with multispectral satellite data, it was determined that the satellite data could be used to differentiate among the various aquaticplant associations common to the river's impoundments. The $1-\mathrm{m}$ resolution of the satellite data affords substantially more accuracy than the estimates made by a land-based observer and, with postprocessing, can be expected to yield unbiased results. Furthermore, airborne hyperspectral data acquisition can more reliably provide higher-resolution imagery for assessing aquatic-macrophyte distribution than the satellitebased remote sensing.

\section{Sediment-Phosphorus Flux}

Two objectives of monitoring sediment-phosphorus flux were achieved: first, in situ measurements of flux were compared with those made by other investigators who collected sediment cores taken from the river and studied sedimentphosphorus flux under laboratory conditions; and second, data describing conditions prior to wastewater-treatment upgrades were assembled for comparison to data describing conditions after completion of the upgrades. Sediment-phosphorus flux was monitored in July, August, and November 2007, 
and in June 2008, by using sampling chambers placed on the river-bottom sediments in free-flowing and impounded river reaches. The chambers effectively isolated sediment and overlying water from their surroundings and allowed the dissolved oxygen inside the chambers to be consumed at rates probably affected by temperature and the amount of decomposable organic matter in the chamber.

Analysis of sampling results showed that the highest rates of phosphorus flux from the sediments were determined in samples from the chambers in July 2007 and June 2008 in the Hudson impoundment. In November 2007, phosphorus concentrations, for the most part, were lower in the water column inside the chambers than at other sampling times. In general, phosphorus fluxes from the sediments were substantially greater in impounded reaches than in free-flowing reaches. In free-flowing reaches, the generally sandy quality of bottom sediments caused by higher water velocities probably contributed to lower sediment oxygen demand, lower phosphorus flux rates, and to increased phosphorus sequestration than in impounded reaches.

Sediment-phosphorus flux results reported by other investigators of the Assabet River were broadly consistent with results of this study. All studies reported losses of phosphorus from the water to the sediments (sequestration) during the cold parts of the year, but the magnitudes of the rates varied considerably among the studies. The conditions required to generate phosphorus release from any of the laboratory or in situ experimental systems rarely occur in the Assabet River impoundments, indicating that the sediment probably does not serve as a major phosphorus source.

The interannual variability in hydrologic conditions and the general heterogeneity of the sediments in the Assabet River impoundments support the need for long-term assessments of water quality. Rate coefficients, such as those used in modeling studies, and the modeling studies themselves could yield realistic results if they incorporated more of the variability inherent in the system under study. Regulatory agencies responsible for evaluating the success of the Assabet River Total Maximum Daily Load for Total Phosphorus now have more baseline information to use in determining whether river sediments are likely to be a source of phosphorus to the water column, and whether the 90-percent reduction in sedimentphosphorus flux has been achieved.

\section{References Cited}

Andersen, J.M., 1982, Effect of nitrate concentration in lake water on phosphate release from the sediment: Water Research, v. 16, no. 7, p. 1119-1126.

Caldwell, J.M., and Doyle, M.C., 1995, Sediment oxygen demand in the Lower Willamette River, Oregon, 1994: U.S. Geological Survey Water-Resources Investigations Report 95-4196, $14 \mathrm{p}$.
Carlson, C.S., DeSimone, L.A., and Weiskel, P.K., 2008, Simulated effects of year 2030 water-use and land-use changes on streamflow near the Interstate-495 Corridor, Assabet and Upper Charles River Basins, Eastern Massachusetts: U.S. Geological Survey Scientific Investigations Report 2008-5132, 108 p.

Camp Dresser \& McKee, Inc., 2007, Assabet River sediment and dam removal study, draft modeling report: Cambridge, Massachusetts, Camp Dresser \& McKee, Inc., variously paged.

Congalton, R.G., 1991, A review of assessing the accuracy of classifications of remotely sensed data: Remote Sensing of Environment, v. 37, p. 35-46.

Cooke, G.D., McComas, M.R., Waller, D.W., and Kennedy, R.H., 1977, The occurrence of internal phosphorus loading in two small, eutrophic, glacial lakes in northeastern Ohio: Hydrobiologia, v. 56, p. 129-135.

DeSimone, L.A., 2004, Simulation of ground-water flow and evaluation of water-management alternatives in the Assabet River Basin, Eastern Massachusetts: U.S. Geological Survey Scientific Investigations Report 2004-5114, 133 p.

Doyle, M.C., and Lynch, D.D., 2005, Sediment oxygen demand in Lake Ewauna and the Klamath River, Oregon, June 2003: U.S. Geological Survey Scientific Investigations Report 2005-5228, $14 \mathrm{p}$.

Doyle, M.C., and Rounds, S.A., 2003, The effect of chamber mixing velocity on bias in measurement of sediment oxygen demand rates in the Tualatin River Basin, Oregon: U.S. Geological Survey Water-Resources Investigations Report 03-4097, $16 \mathrm{p}$.

ENSR International, 2001, SuAsCo Watershed Assabet River TMDL Study Phase One-Assessment final report: Westford, Massachusetts, ENSR International, variously paged.

ENSR International, 2005, SuAsCo Watershed Assabet River TMDL Study Phase Two-Analysis final report: Westford, Massachusetts, ENSR International, variously paged.

Kuwabara, J.S., Berelson, W.M., Balistrieri, L.S., Woods, P.F., Topping, B.R., Steding, D.J., and Krabbenhoft, D.P., 2000, Benthic flux of metals and nutrients into the water column of Lake Coeur d'Alene, Idaho-Report of an August, 1999, pilot study: U.S. Geological Survey Water-Resources Investigations Report 00-4132, 74 p.

Lee, D.R., 1977, A device for measuring seepage flux in lakes and estuaries: Limnology and Oceanography, v. 22, no. 1, p. 140-147. 
Commonwealth of Massachusetts, 2004, Assabet River total maximum daily load for total phosphorus: Boston, Commonwealth of Massachusetts, Department of Environmental Protection, report no. MA82B-01-2004-01, 104 p.

McAdow, Ron, 1990, The Concord, Sudbury, and Assabet Rivers-A guide to canoeing, wildlife, and history: Marlborough, Massachusetts, Bliss Publishing Company, Inc., $223 \mathrm{p}$.

Parker, G.W., Armstrong, D.S., and Richards, T.A., 2004, Comparison of methods for determining streamflow requirements for aquatic habitat protection at selected sites on the Assabet and Charles Rivers: U.S. Geological Survey Scientific Investigations Report 2004-5092, 72 p.

Rounds, S.A., and Doyle, M.C., 1997, Sediment oxygen demand in the Tualatin River Basin, Oregon, 1992-96: U.S. Geological Survey Water-Resources Investigations Report 97-4103, 19 p.

Ryding, S-O., and Forsberg, Curt, 1976, Six polluted lakes-A preliminary evaluation of the treatment and recovery processes: Ambio, v. 5, no. 4, p. 151-156.

Sonzogni, W.C., Larsen, D.P., Malueg, K.W., and Schuldt, M.D., 1977, Use of large submerged chambers to measure sediment water interactions: Water Research, v. 11, p. 461-464.
Tian Y.Q., Yu Qian, Zimmerman, M.J., Flint, Suzanne, and Waldron, M.C., 2010, Differentiating aquatic plant communities in a eutrophic river using hyperspectral and multispectral remote sensing: Freshwater Biology, v. 55, no. 8, p. $1658-1673$.

Tirén, Torbjörn, and Pettersson, Kurt, 1985, The influence of nitrate on the phosphorus flux to and from oxygen depleted lake sediments: Hydrobiologia, v. 120, no. 3, p. 207-223.

Wetzel, R.G., 2001, Limnology, lake and river ecosystems (3d ed.): San Diego, California, Academic Press, 1006 p.

Wood, T.M., 2001, Sediment oxygen demand in Upper Klamath and Agency Lakes, Oregon, 1999: U.S. Geological Survey Water-Resources Investigations Report 01-4080, 13 p.

Zimmerman, M.J., Massey, A.J., and Campo, K.W., 2005, Pushpoint sampling for defining spatial and temporal variations in contaminant concentrations in sediment pore water near the ground-water/surface-water interface: U.S. Geological Survey Scientific Investigations Report 2005-5036, $70 \mathrm{p}$.

Zimmerman, M.J., and Sorenson, J.R., 2005, Sediment studies in the Assabet River, central Massachusetts, 2003: U.S. Geological Survey Scientific Investigations Report 20055131, 87 p. 
THIS PAGE INTENTIONALLY LEFT BLANK 
Figures 3-9

Figures 3-9 


\section{A. Allen Street}

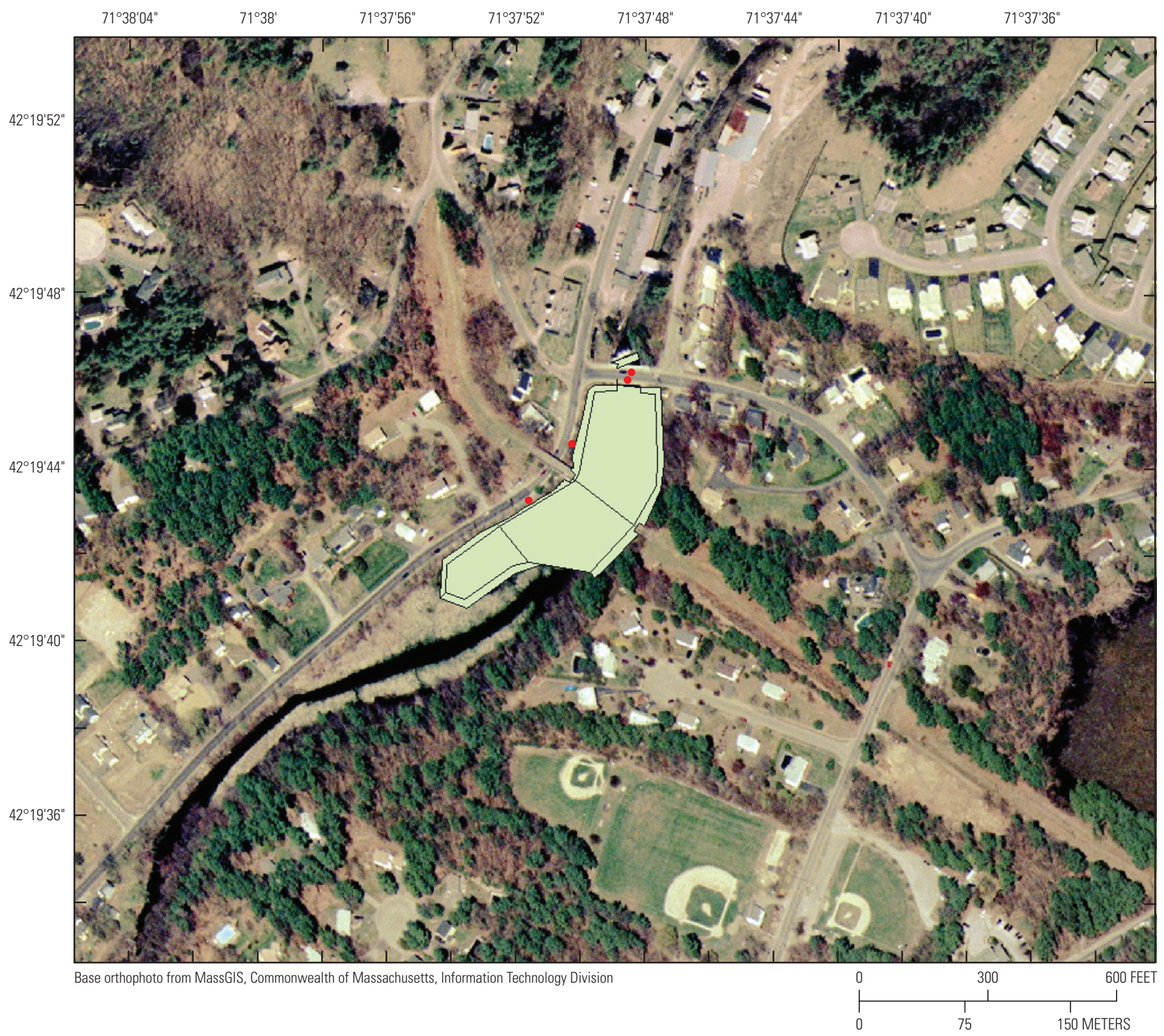

Figure 3. Grid structure used for identifying Lemna distribution in Assabet River impoundments: $A$, Allen Street impoundment; $B$, Hudson impoundment; $C$, Gleasondale impoundment; $D$, Ben Smith impoundment; and $E$, Powdermill impoundment. Red dots represent observation points. 


\section{B. Hudson}

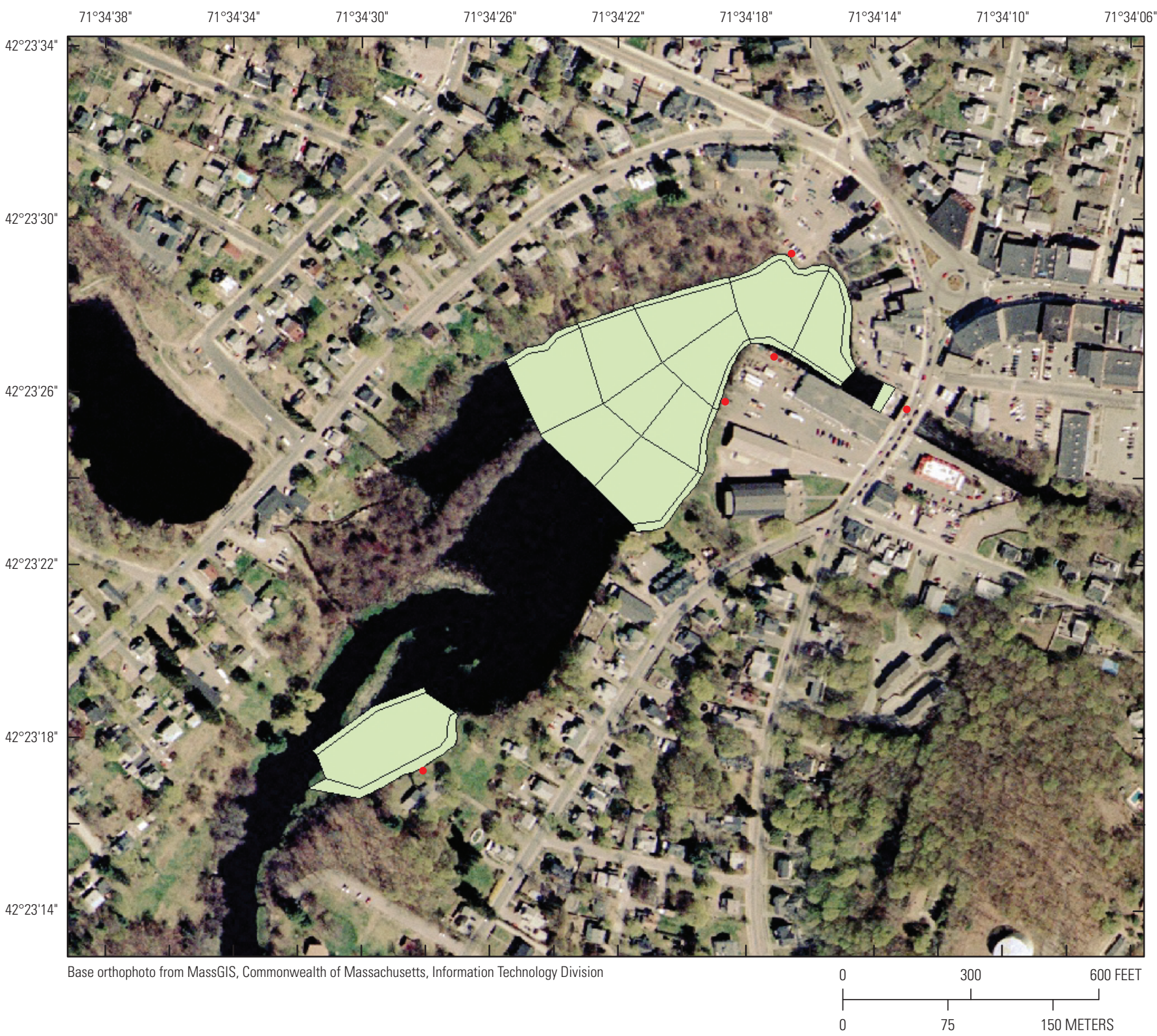

Figure 3.-Continued. 


\section{Gleasondale}

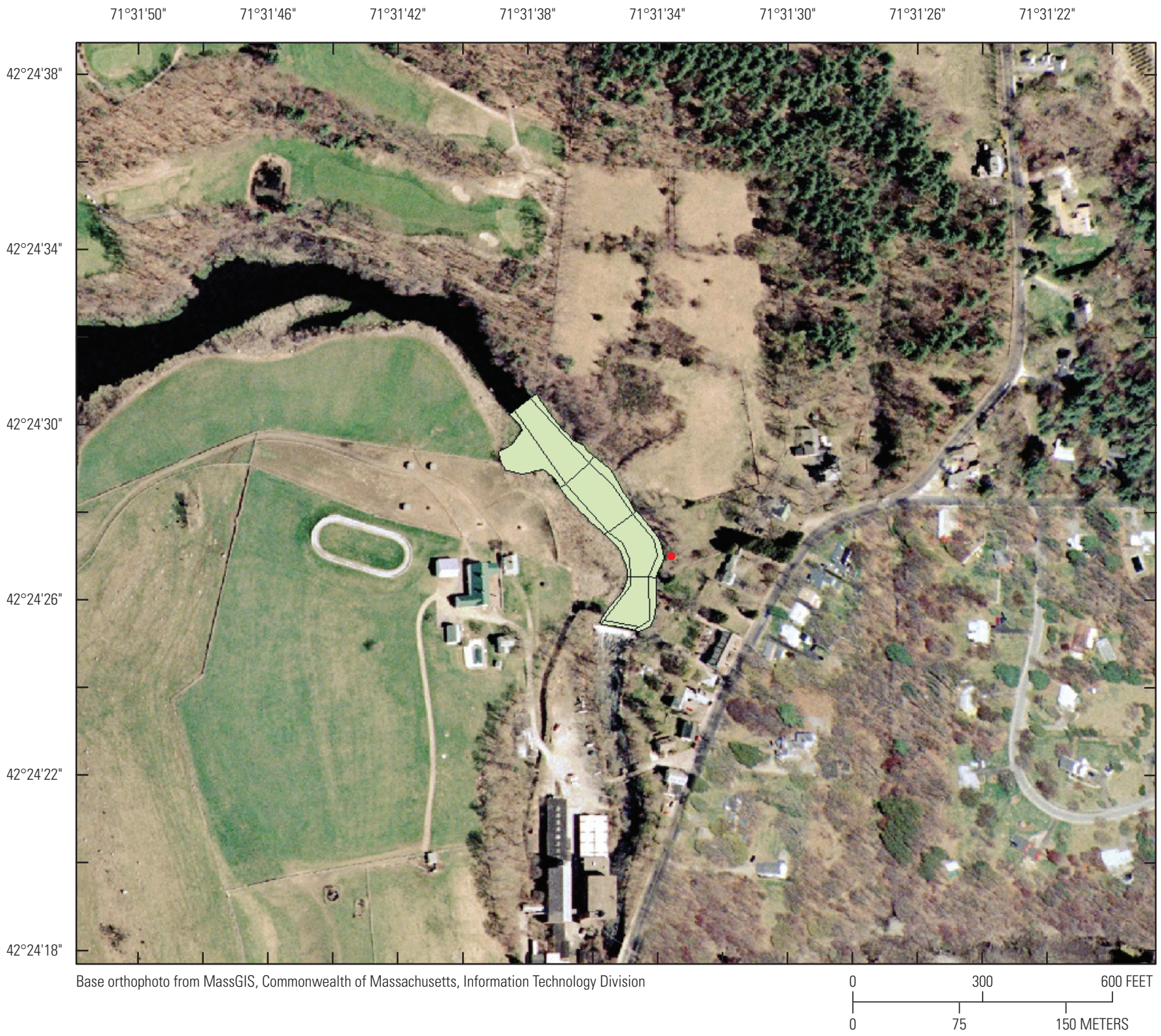

Figure 3.-Continued. 
D. Ben Smith

$71^{\circ} 28^{\prime} 50^{\prime \prime}$

$71^{\circ} 28^{\prime} 42^{\prime \prime}$

71²8'34"

$71^{\circ} 28^{\prime} 26^{\prime \prime}$

$71^{\circ} 28^{\prime} 18^{\prime \prime}$

$71^{\circ} 28^{\prime} 10^{\prime \prime}$

$71^{\circ} 28^{\prime} 02^{\prime \prime}$

$71^{\circ} 27^{\prime} 54^{\prime \prime}$

$71^{\circ} 27^{\prime} 46^{\prime \prime}$

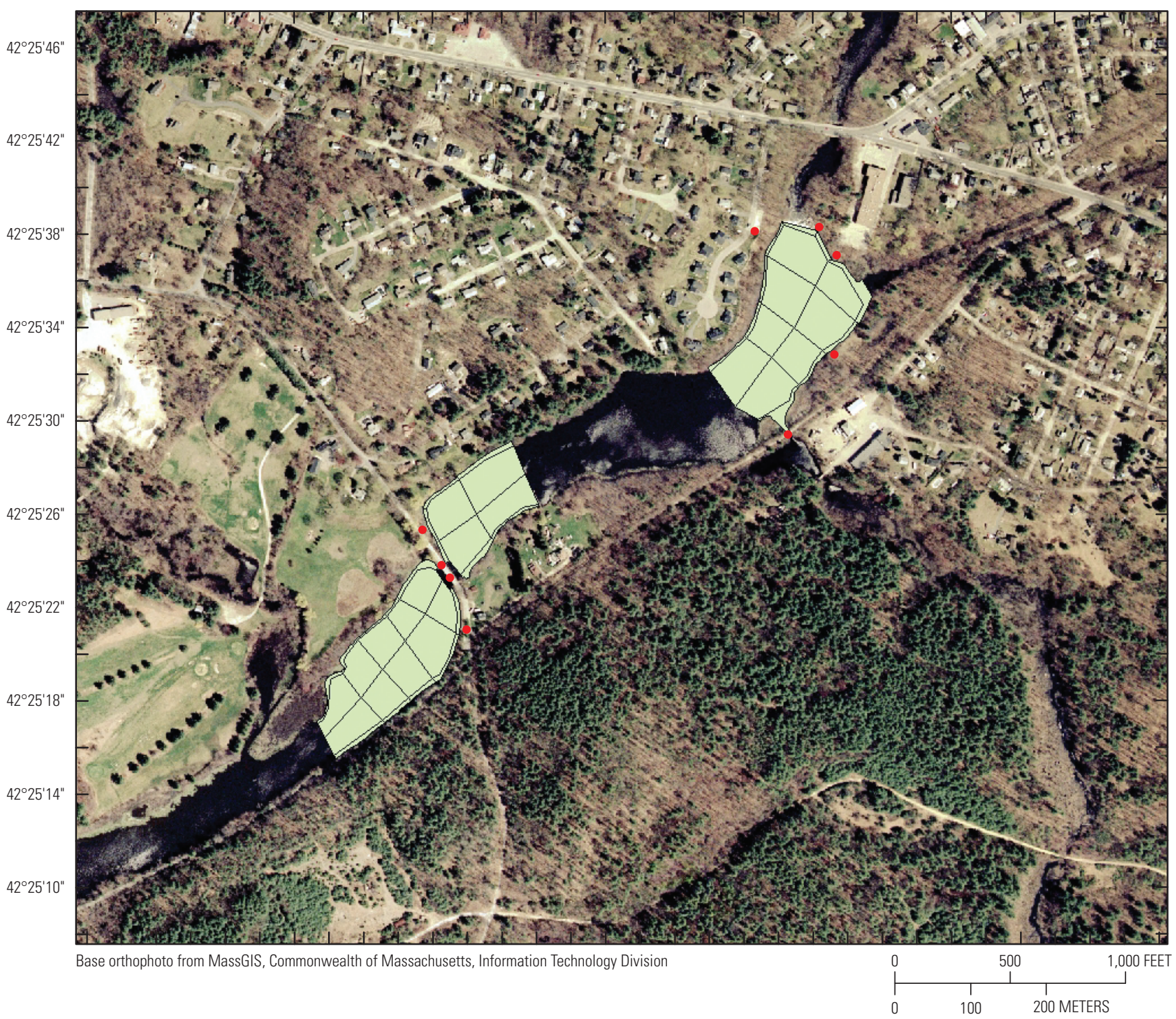

Figure 3.-Continued. 


\section{E. Powdermill}

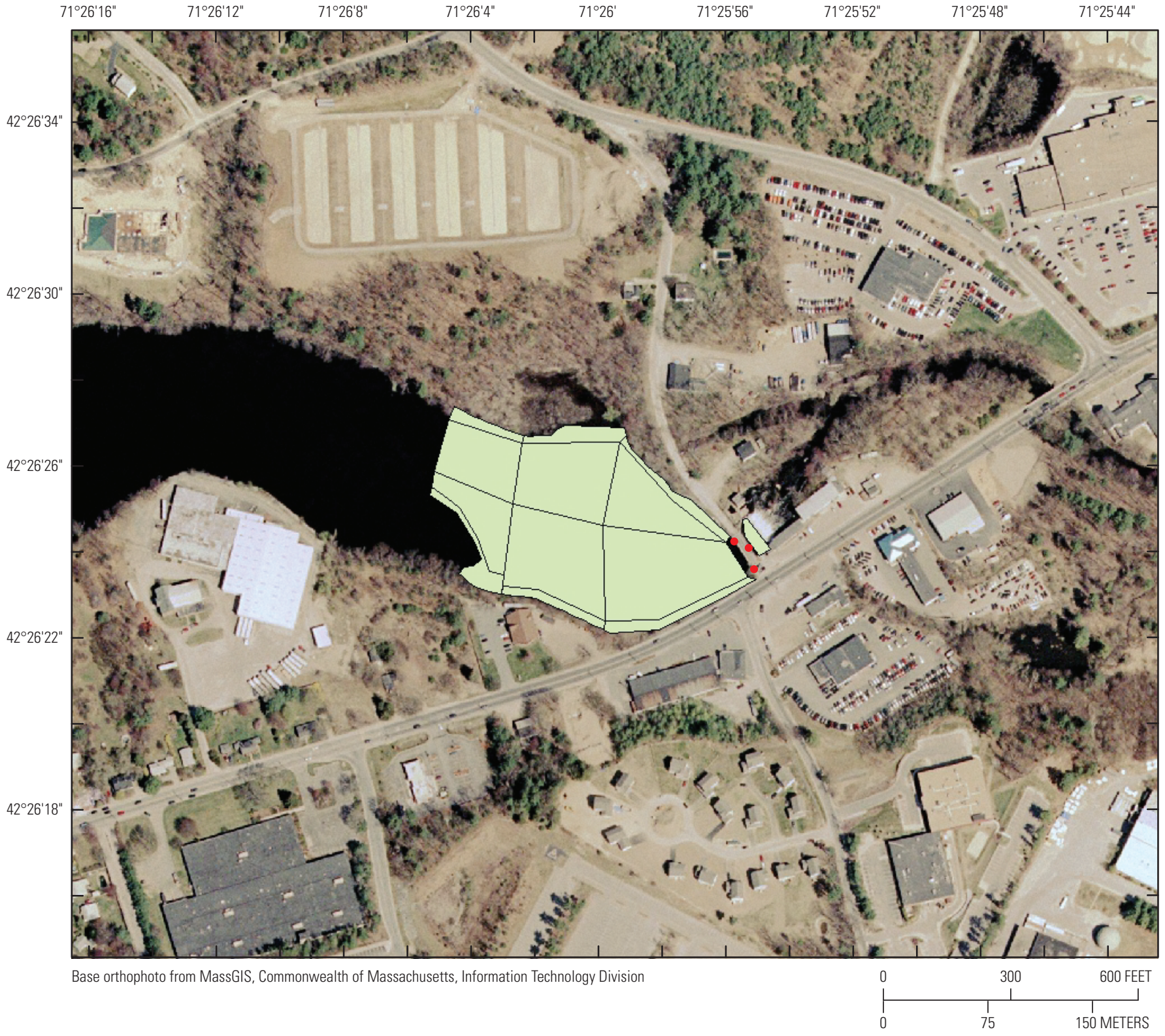

Figure 3.-Continued. 

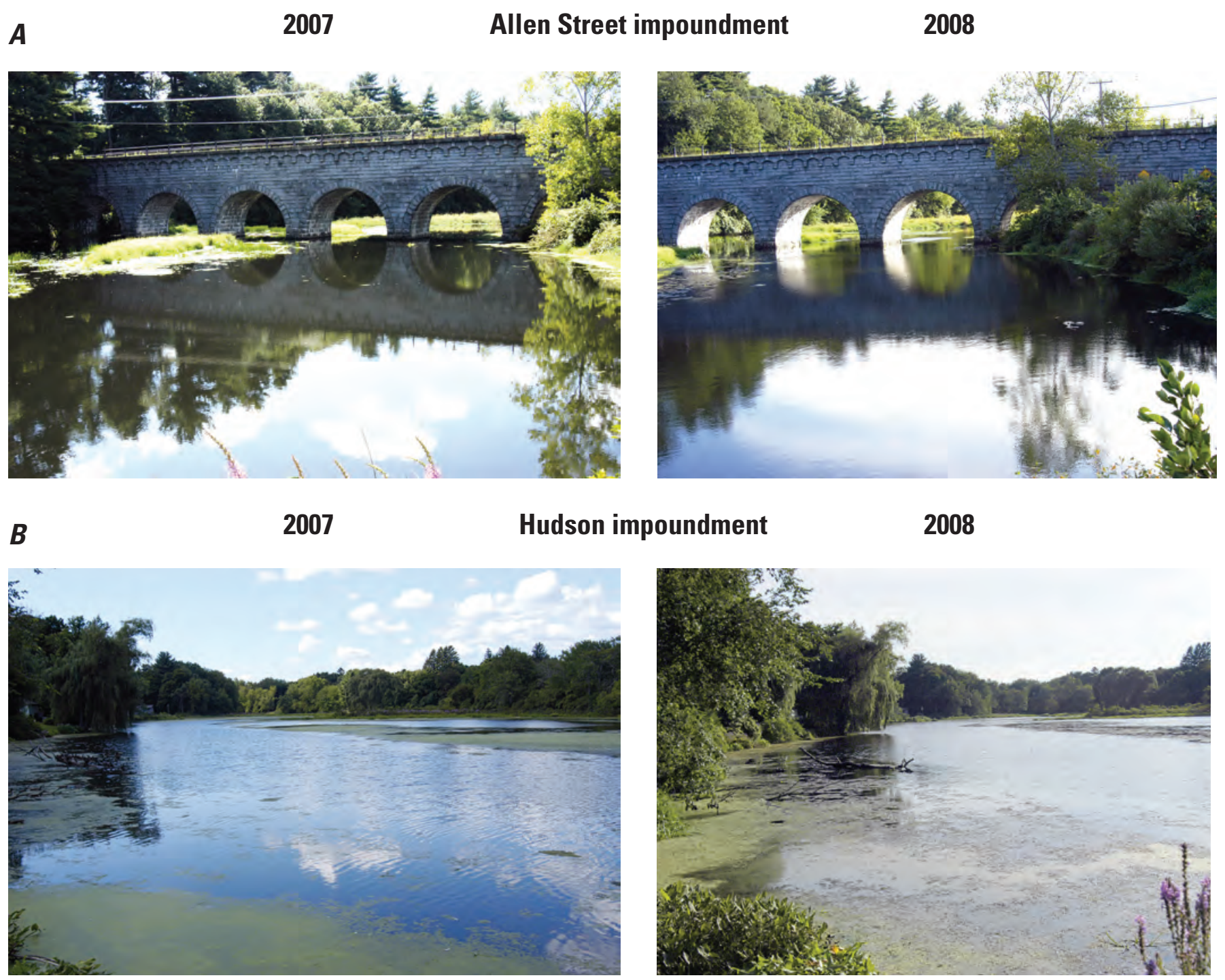

C

Cove in Hudson impoundment
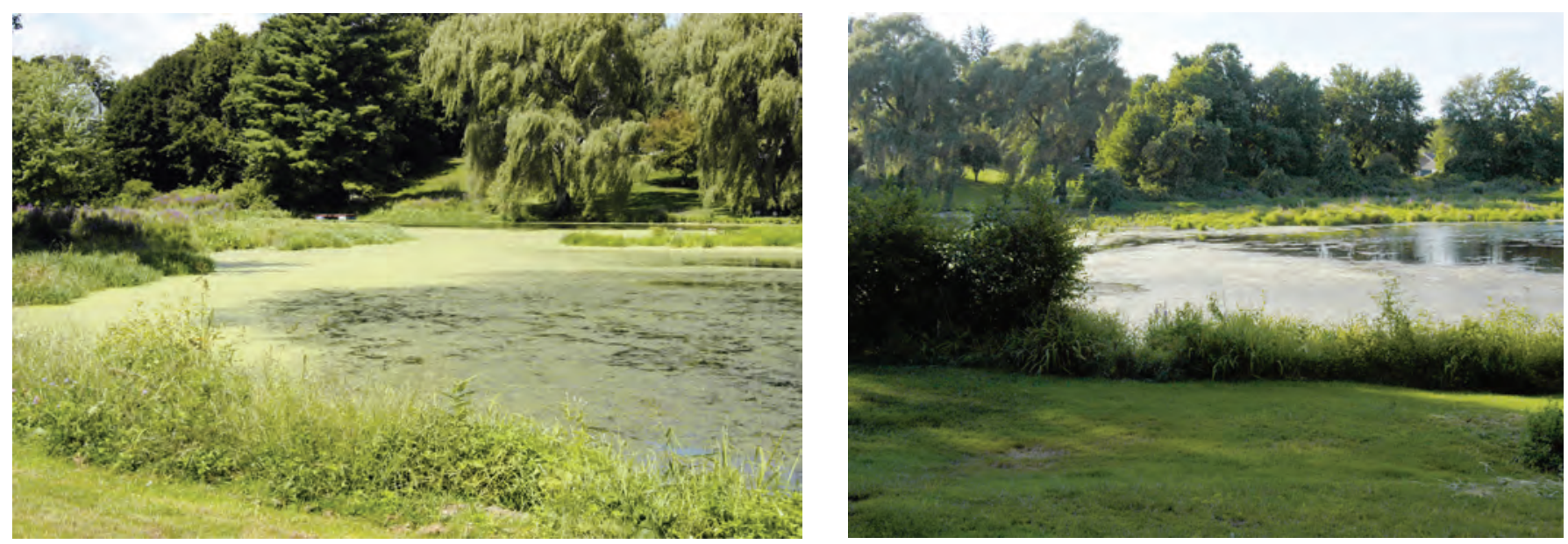

Figure 4. Differences in Lemna coverage on comparable dates (August 27, 2007, and August 28, 2008) at sites where Lemna visual observations were made during this study: $A$, Allen Street impoundment; $B$, Hudson impoundment; $C$, a cove in the Hudson impoundment; $D$, Gleasondale impoundment; $E$, Ben Smith impoundment near the dam; F, Ben Smith impoundment downstream from the White Pond Road bridge; G, Ben Smith impoundment upstream from the White Pond Road bridge; and $H$, Powdermill impoundment. 

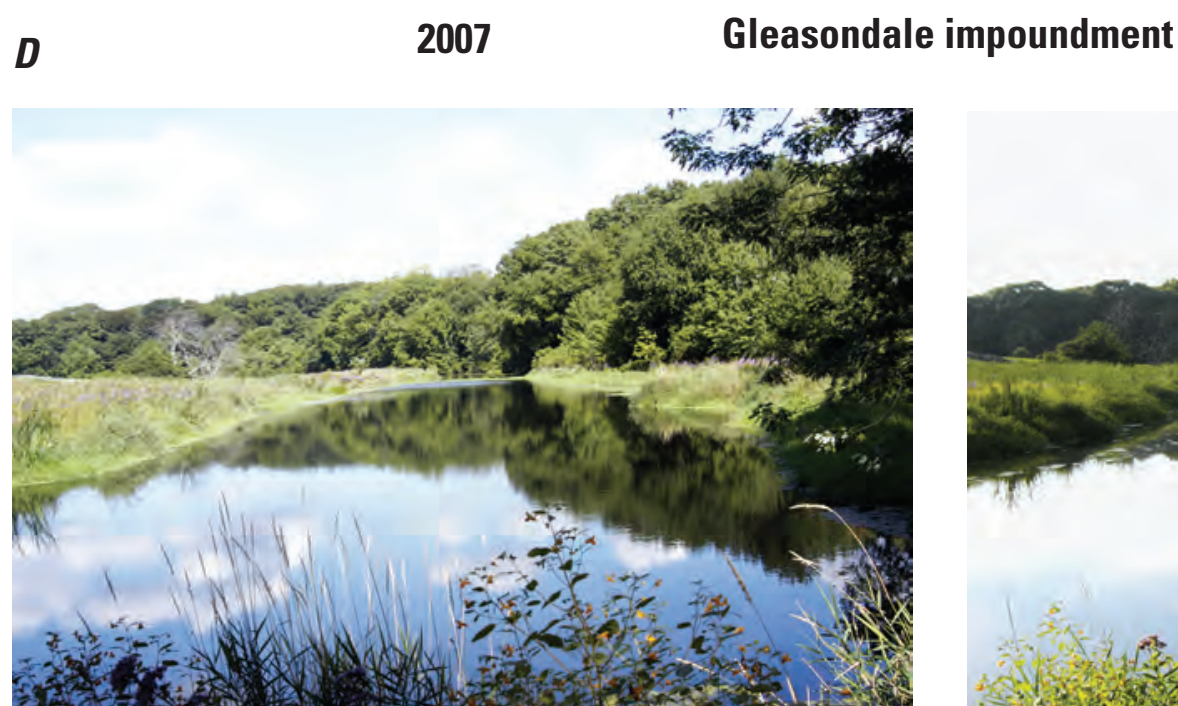

$\boldsymbol{E}$

Ben Smith impoundment near dam
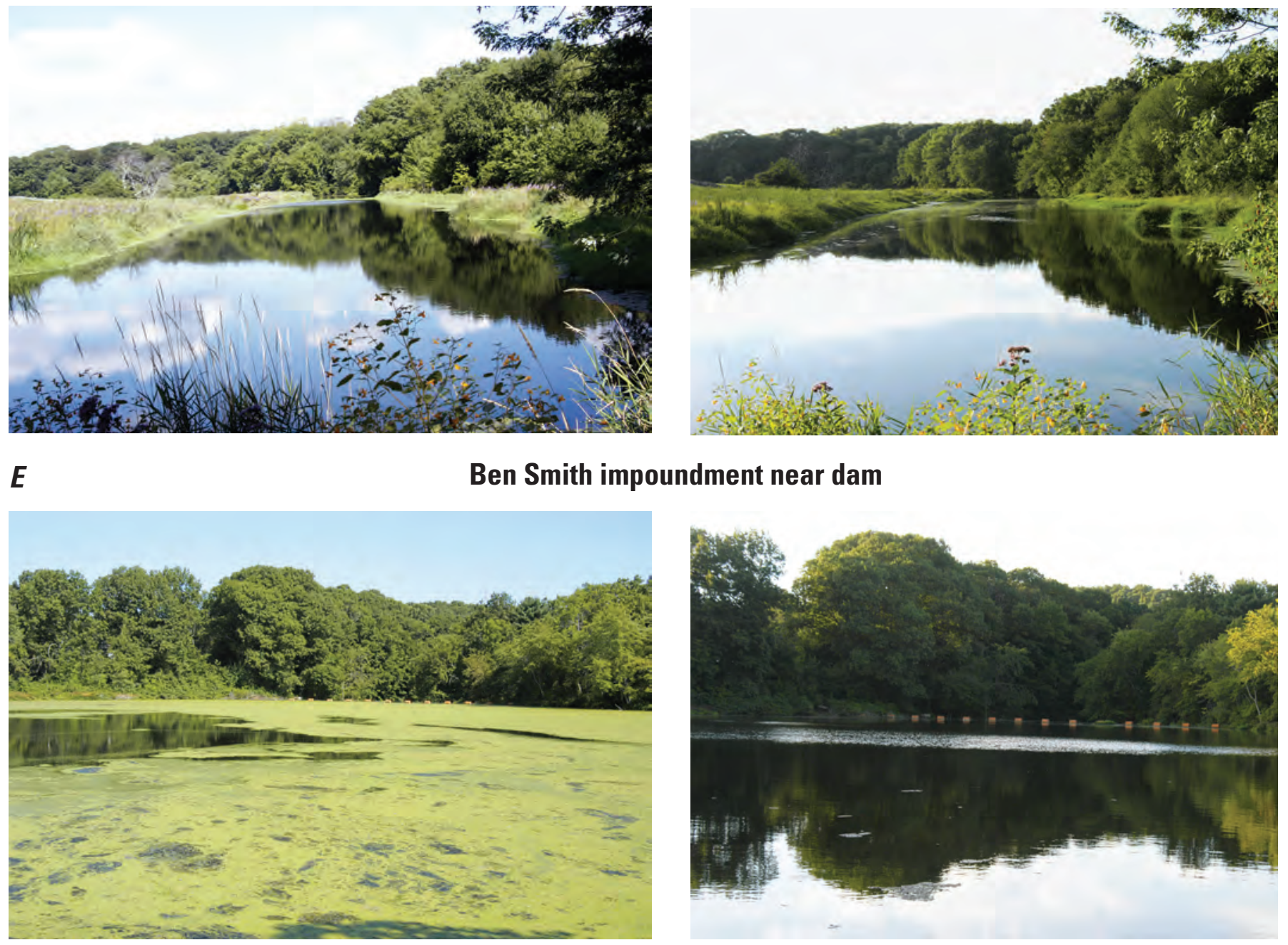

Figure 4.-Continued. 


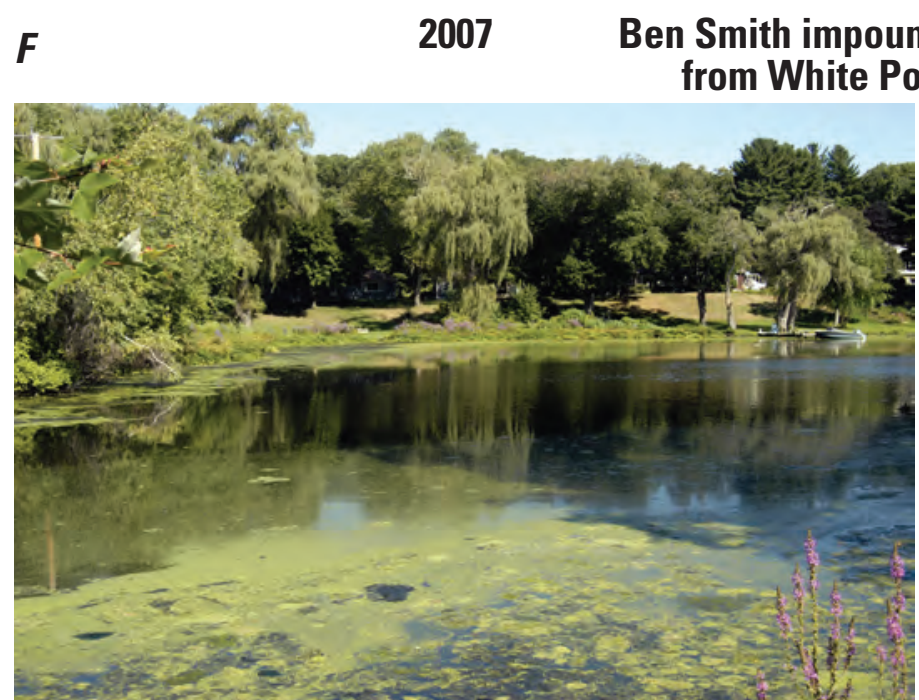

2008
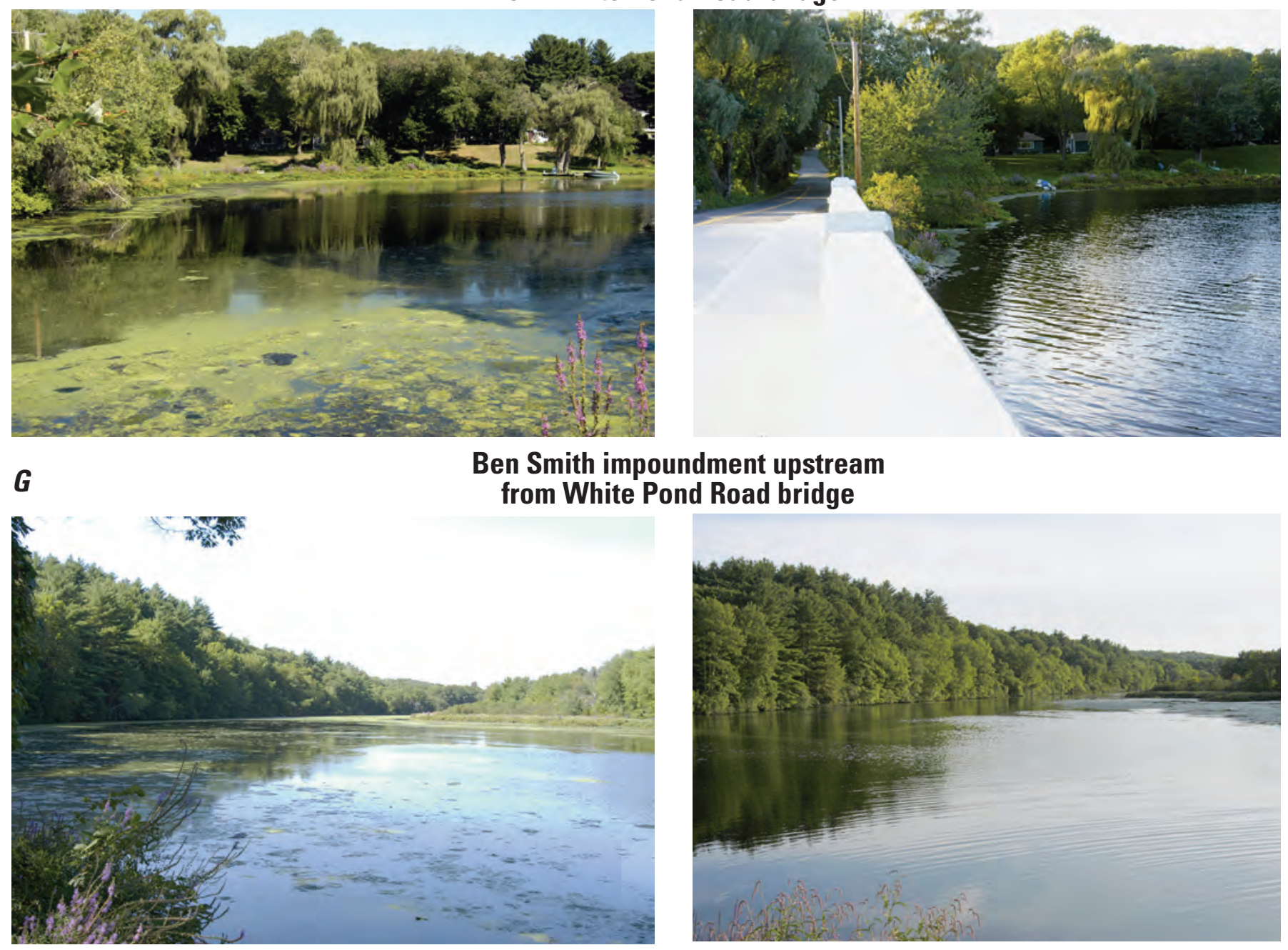

G

en Smith impoundment upstream
from White Pond Road bridge

H

2007

Powdermill impoundment

2008
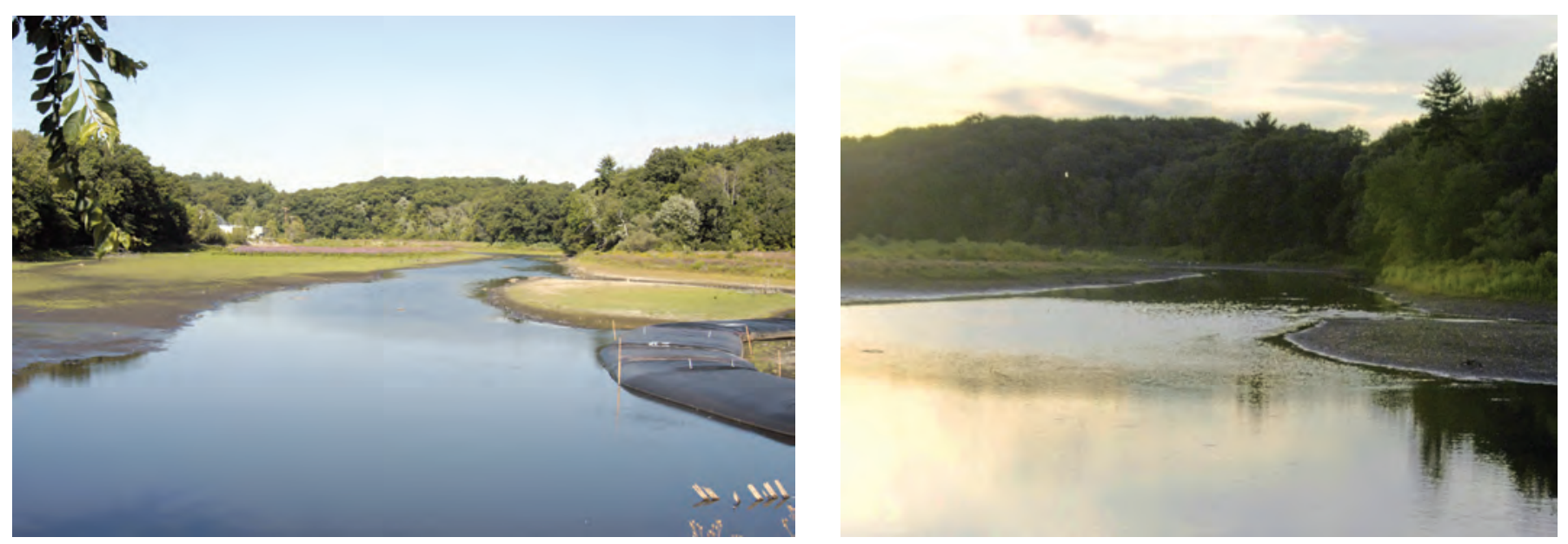

Figure 4.-Continued. 
A
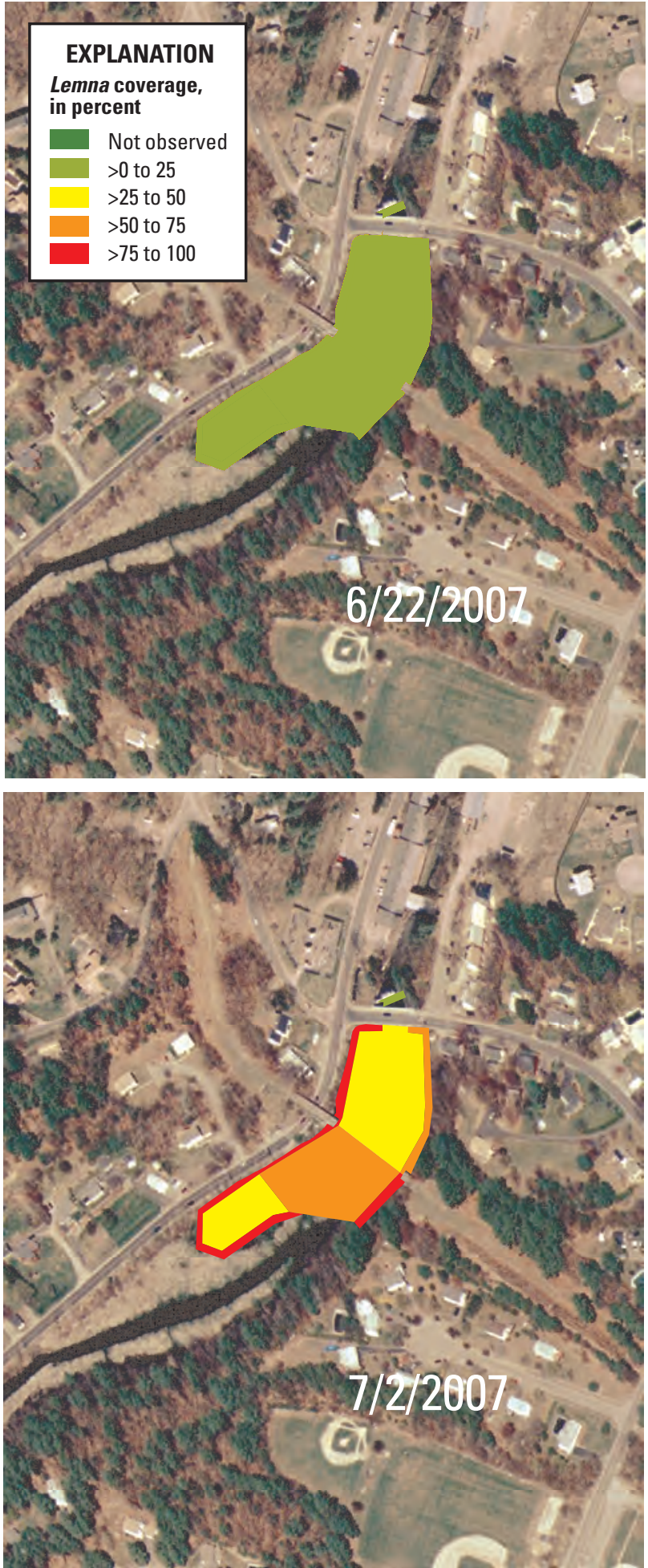

Base orthophoto from MassGIS, Commonwealth of Massachusetts, Information Technology Division
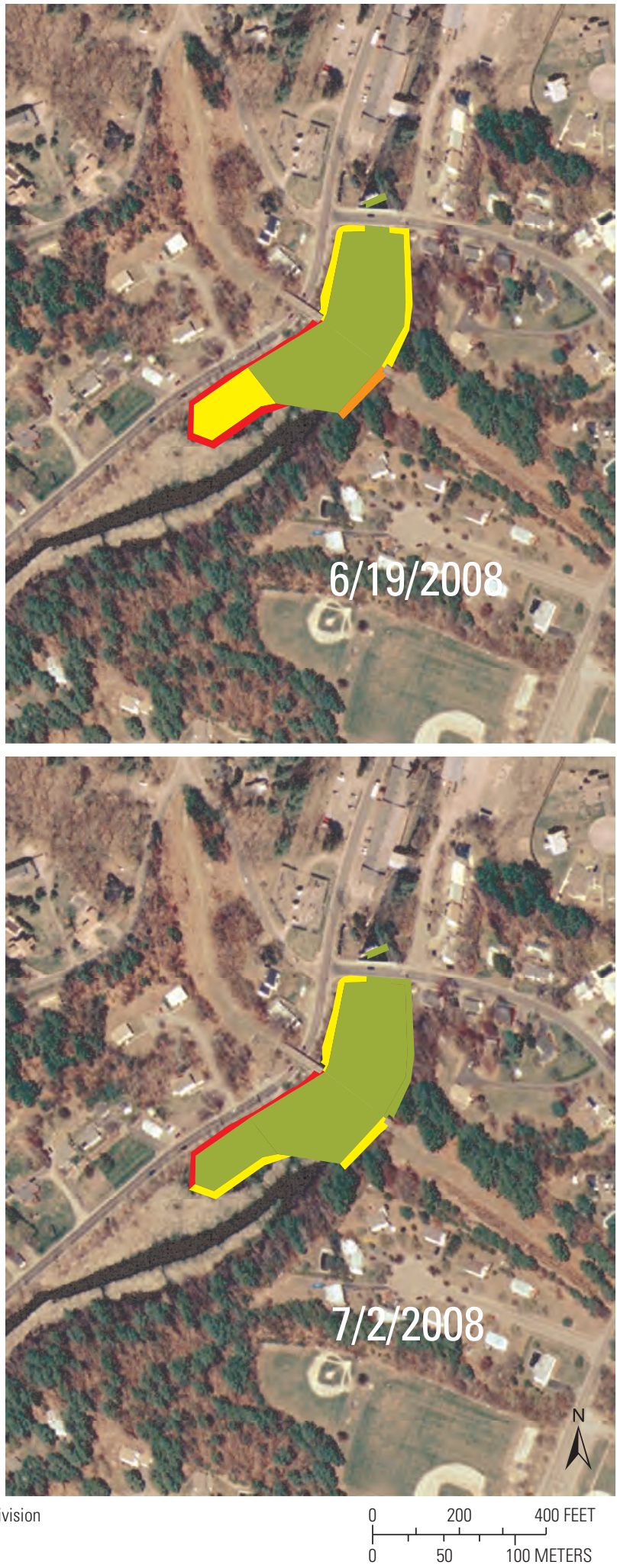

Figure 5. Percent coverages of Lemna in the Allen Street impoundment based on visual observations on comparable dates in 2007 and 2008. >, greater than. 
B
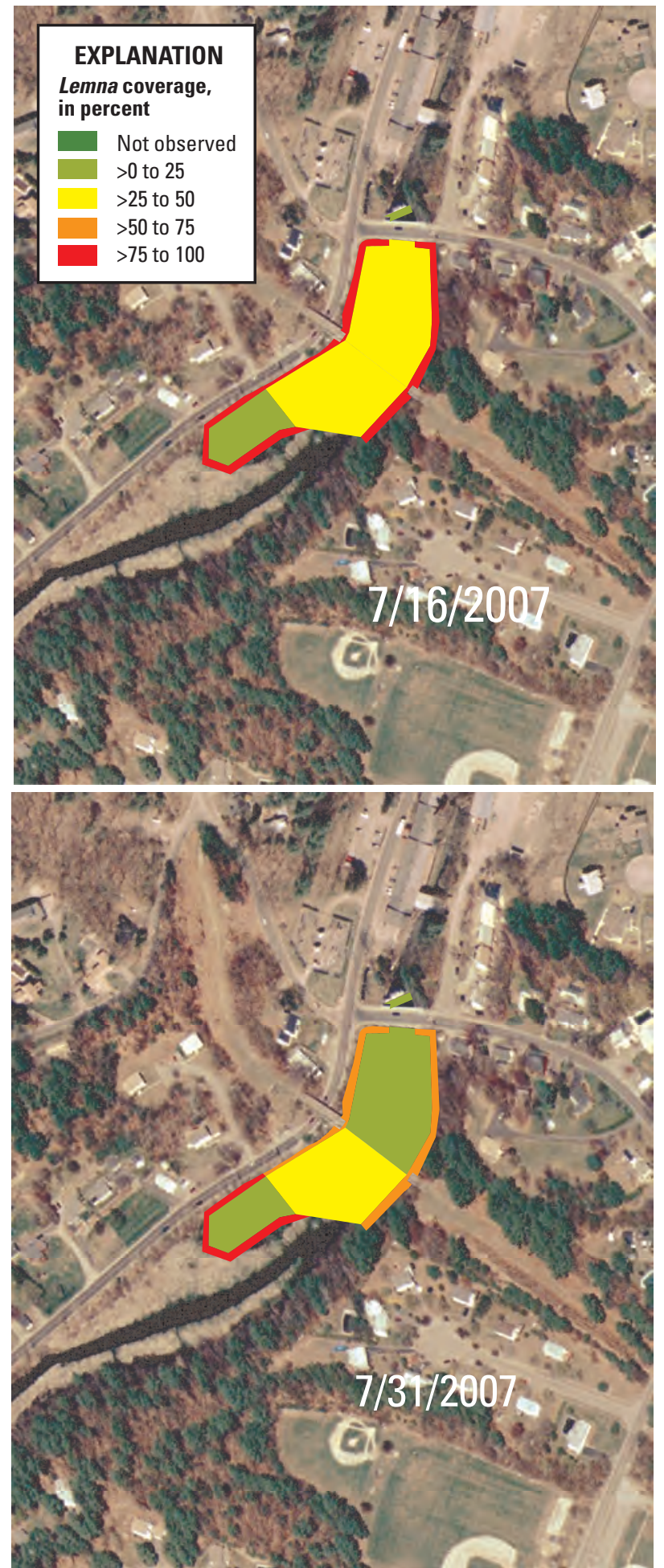

2007
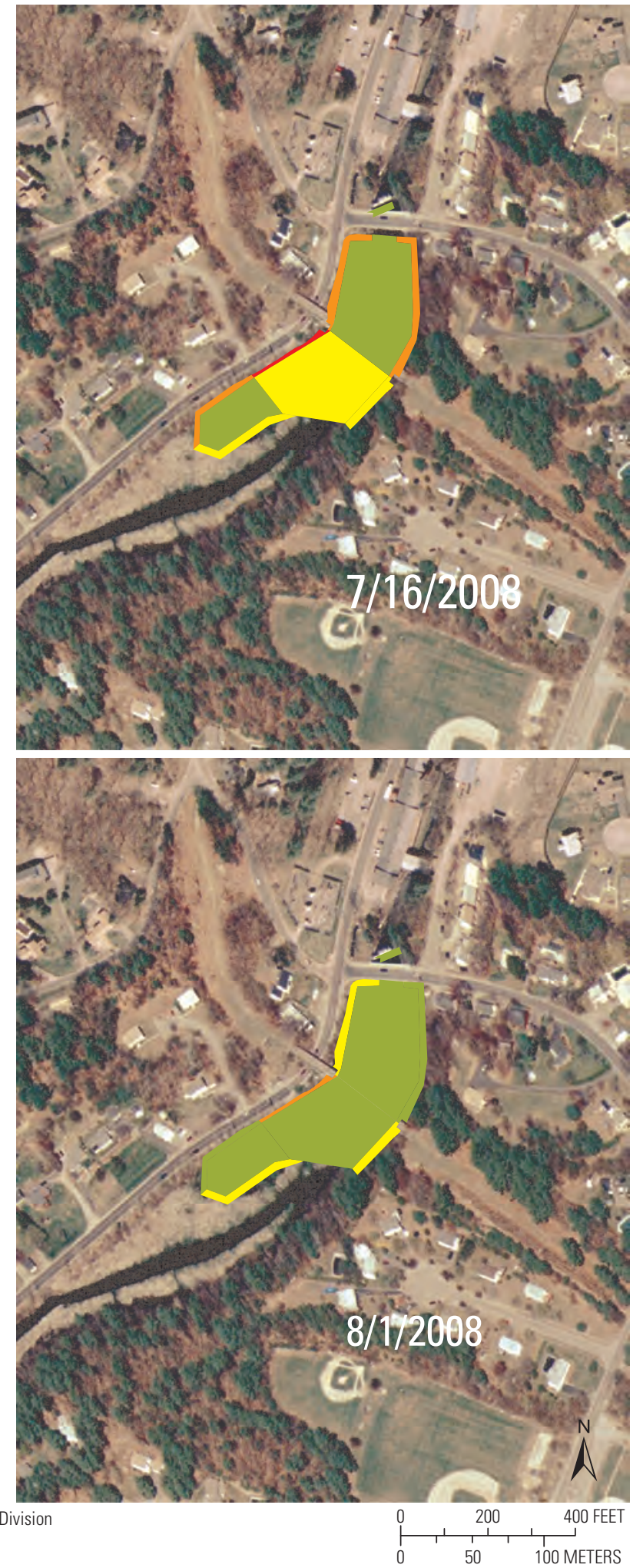

Figure 5.-Continued. 
C
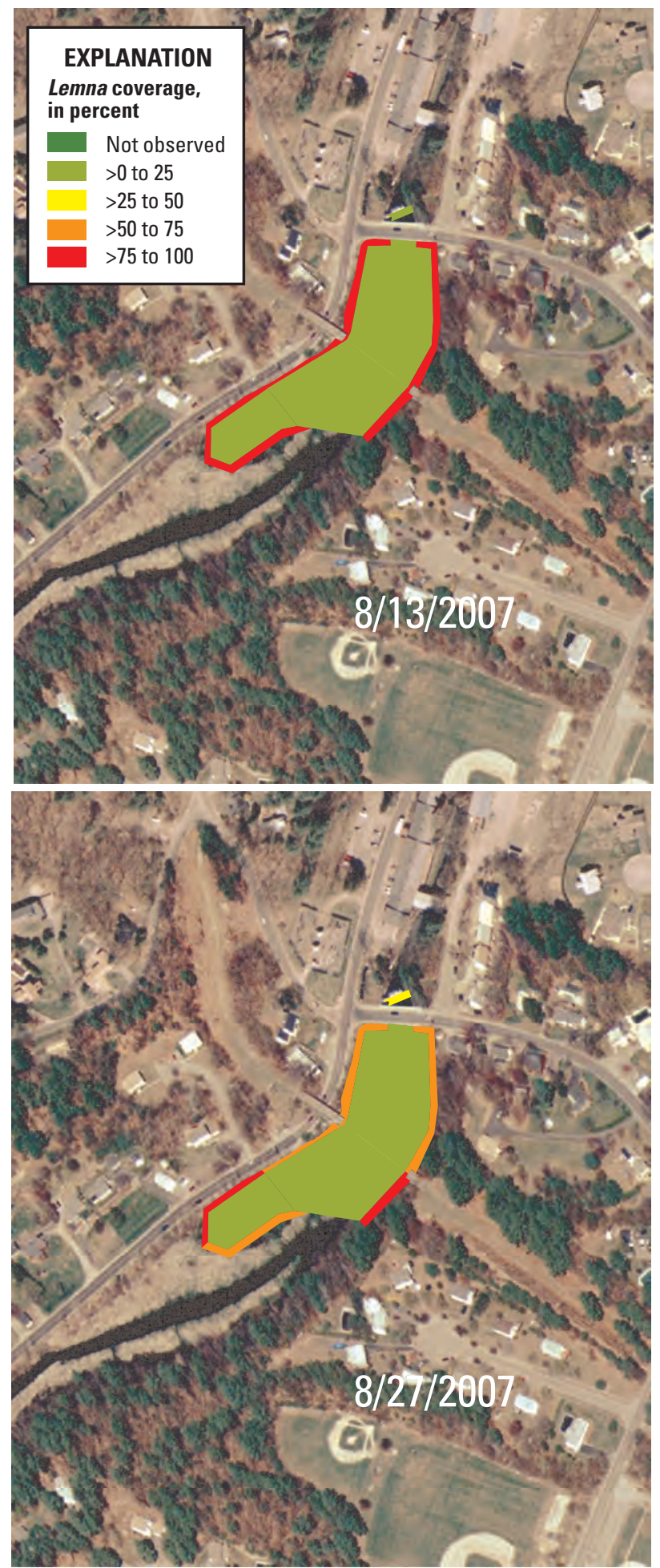

2007
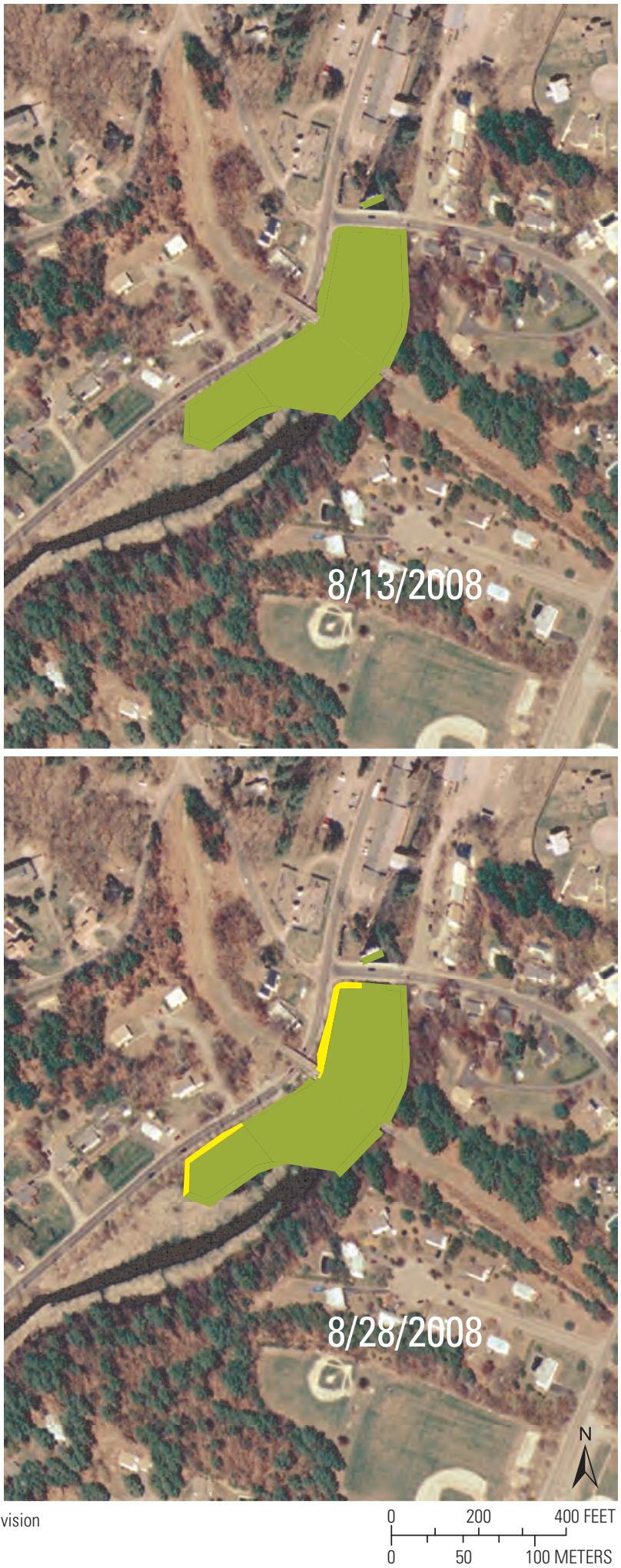

Figure 5.-Continued. 
D
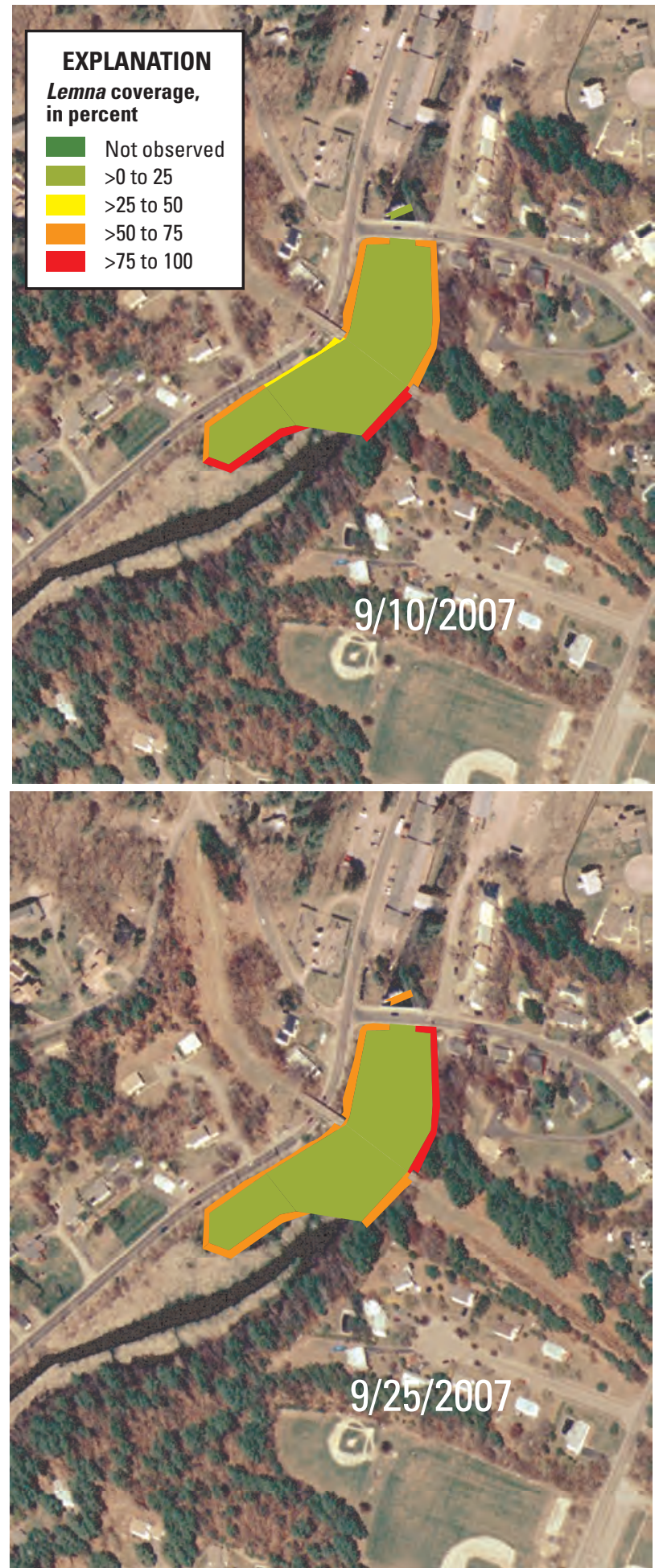

Base orthophoto from MassGIS, Commonwealth of Massachusetts, Information Technology Division
2008
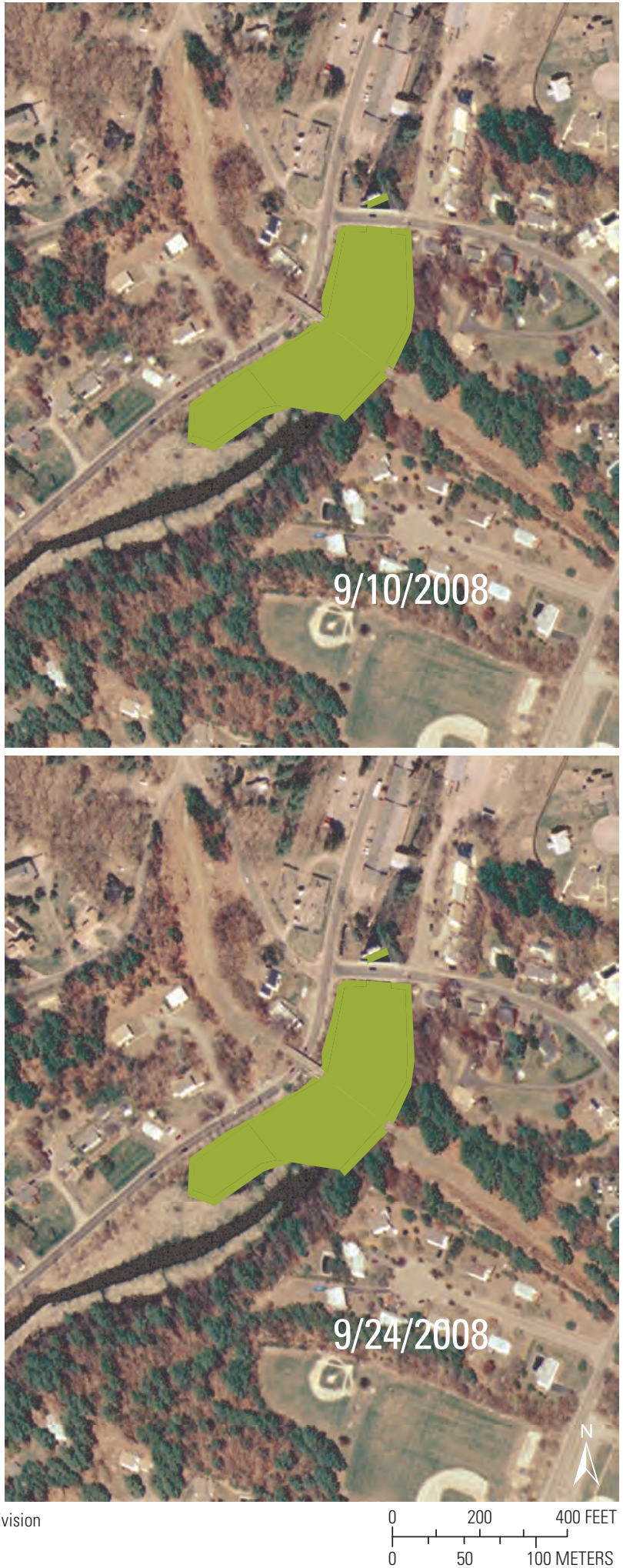

Figure 5.-Continued. 
$\boldsymbol{A}$
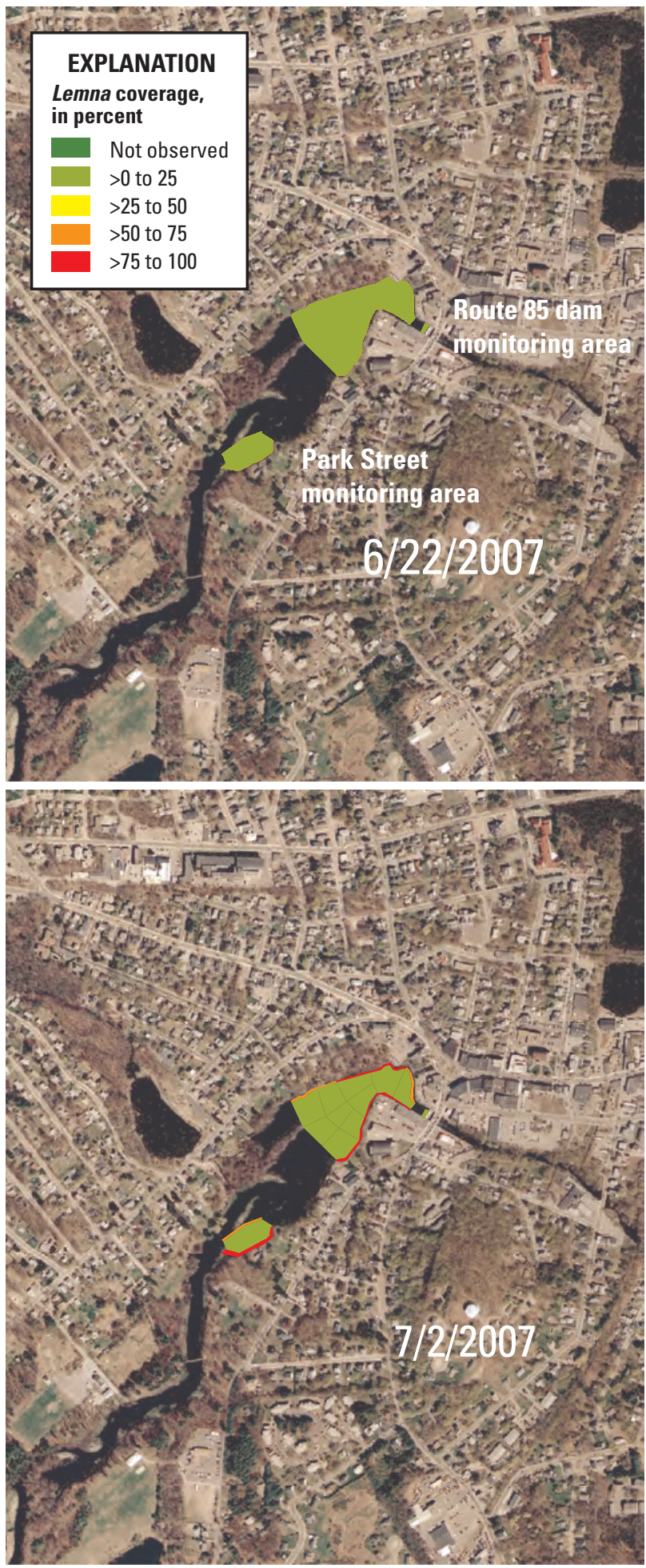

Base orthophoto from MassGIS, Commonwealth of Massachusetts, Information Technology Division
2008
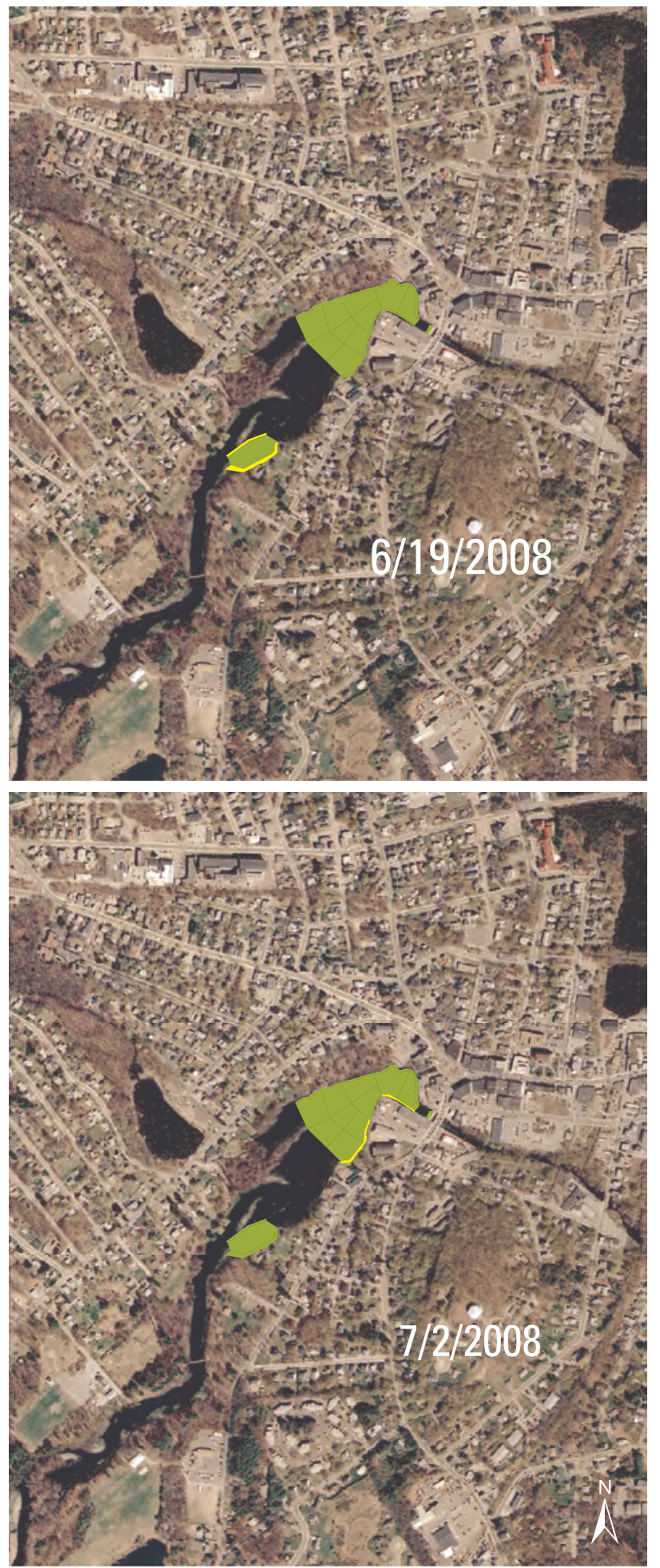

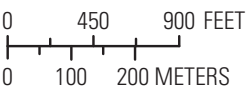

Figure 6. Percent coverages of Lemna in the Hudson impoundment near Park Street and the Route 85 dam based on visual observations on comparable dates in 2007 and 2008. >, greater than. 
B
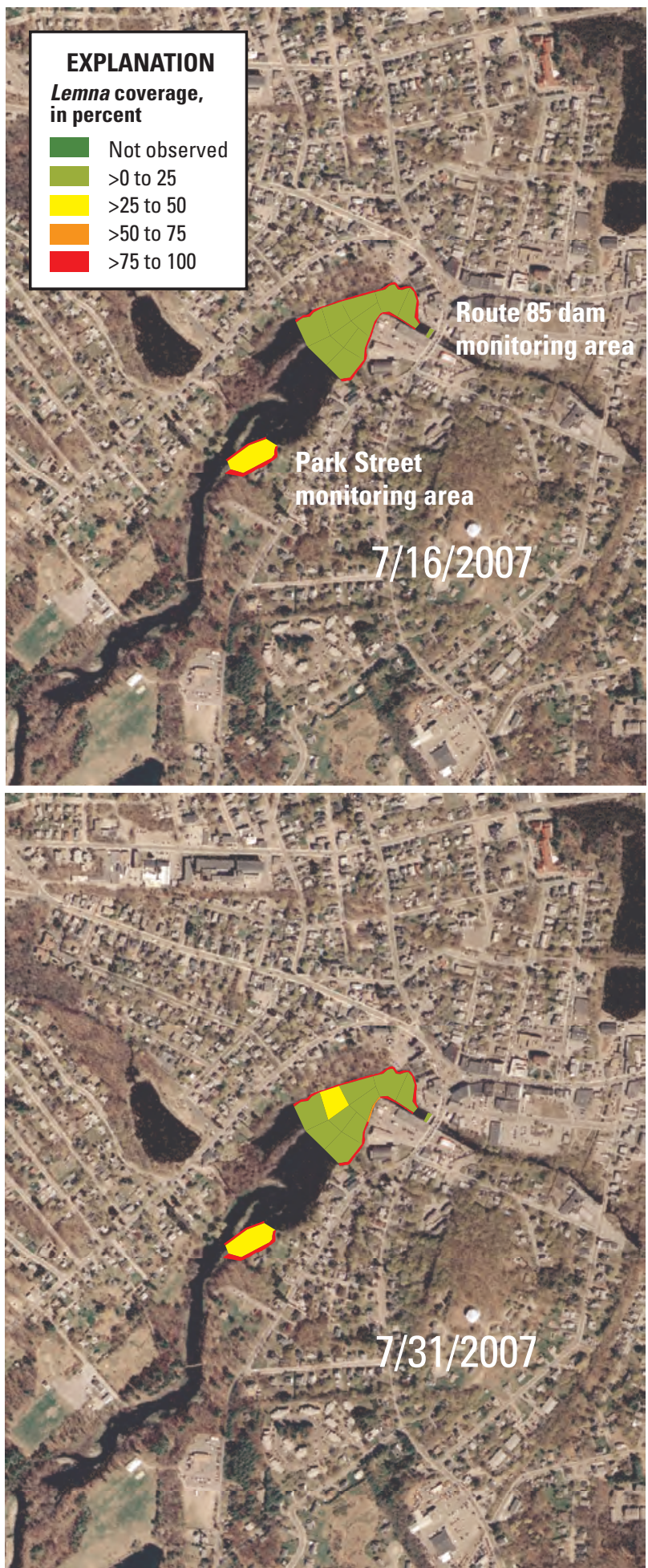

Base orthophoto from MassGIS, Commonwealth of Massachusetts, Information Technology Division

\section{8}
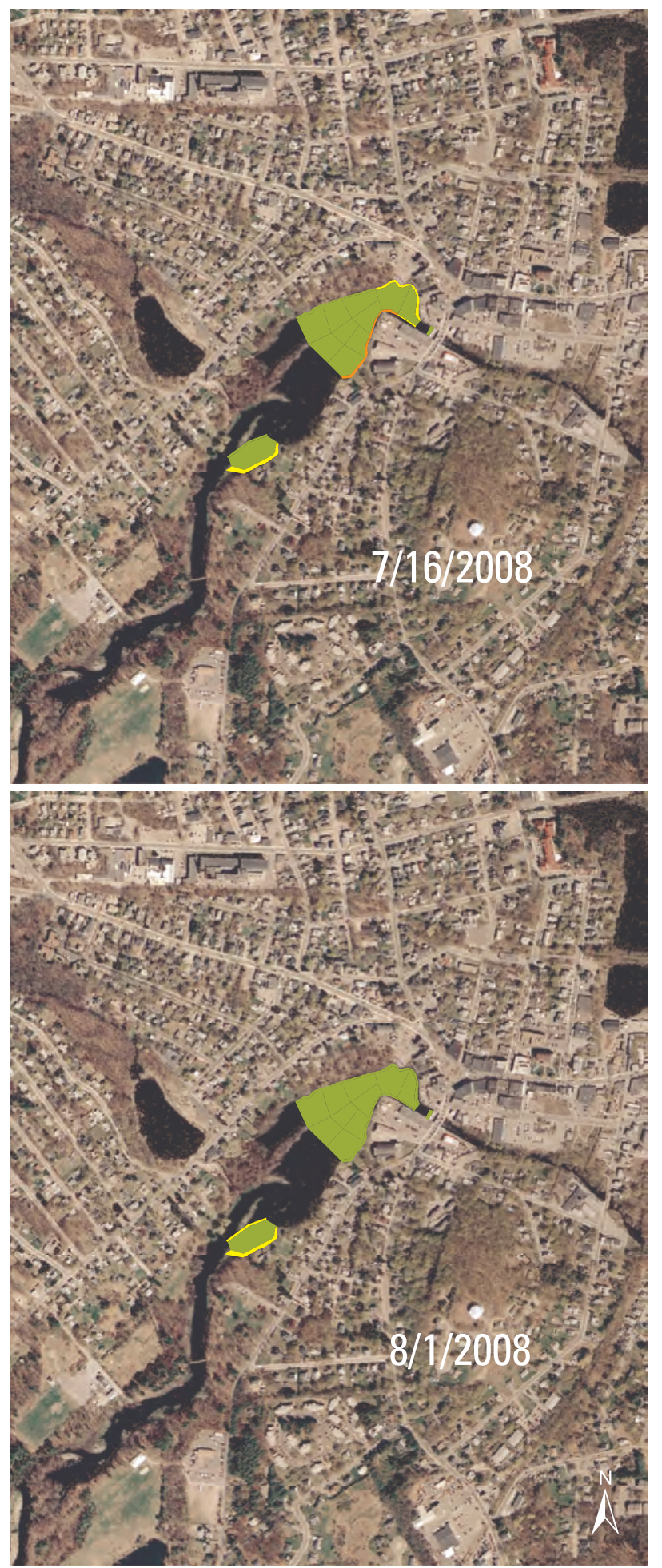

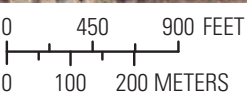

Figure 6.-Continued. 
C
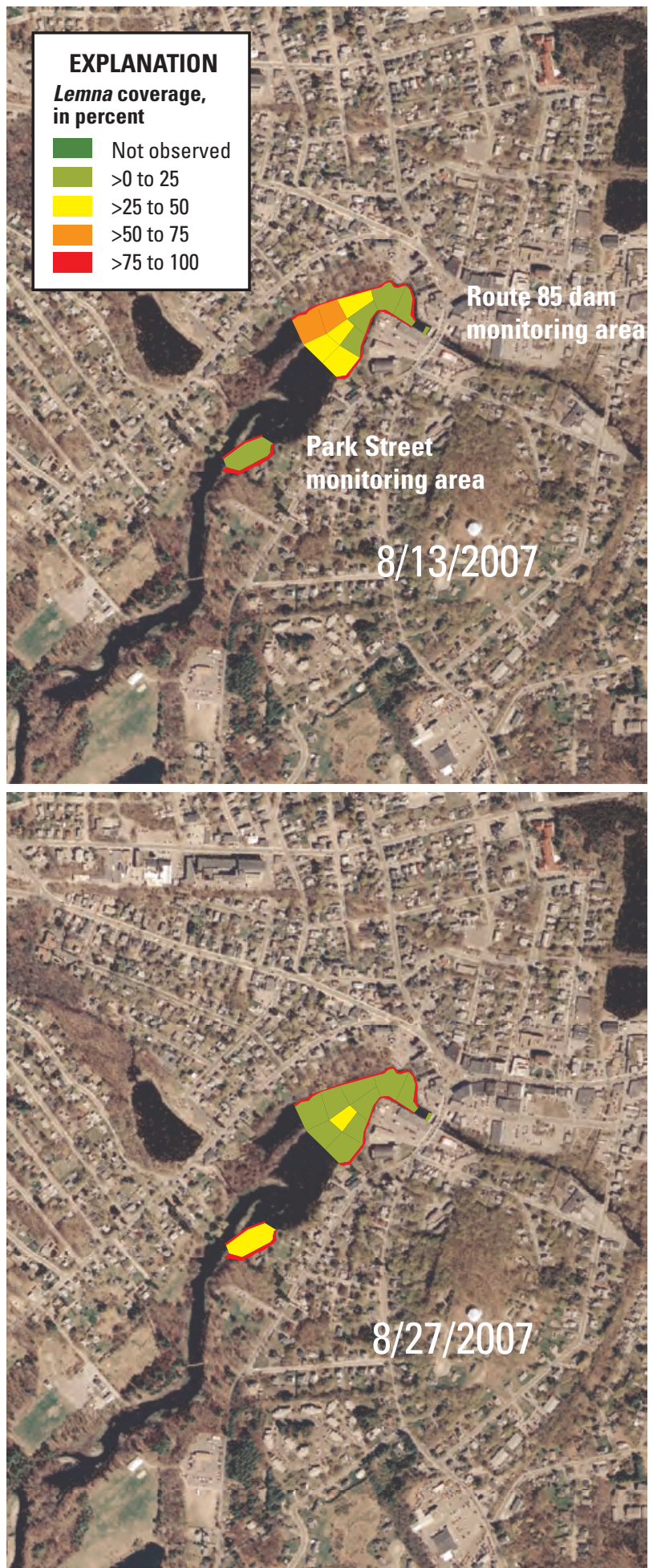

Base orthophoto from MassGIS, Commonwealth of Massachusetts, Information Technology Division
2008
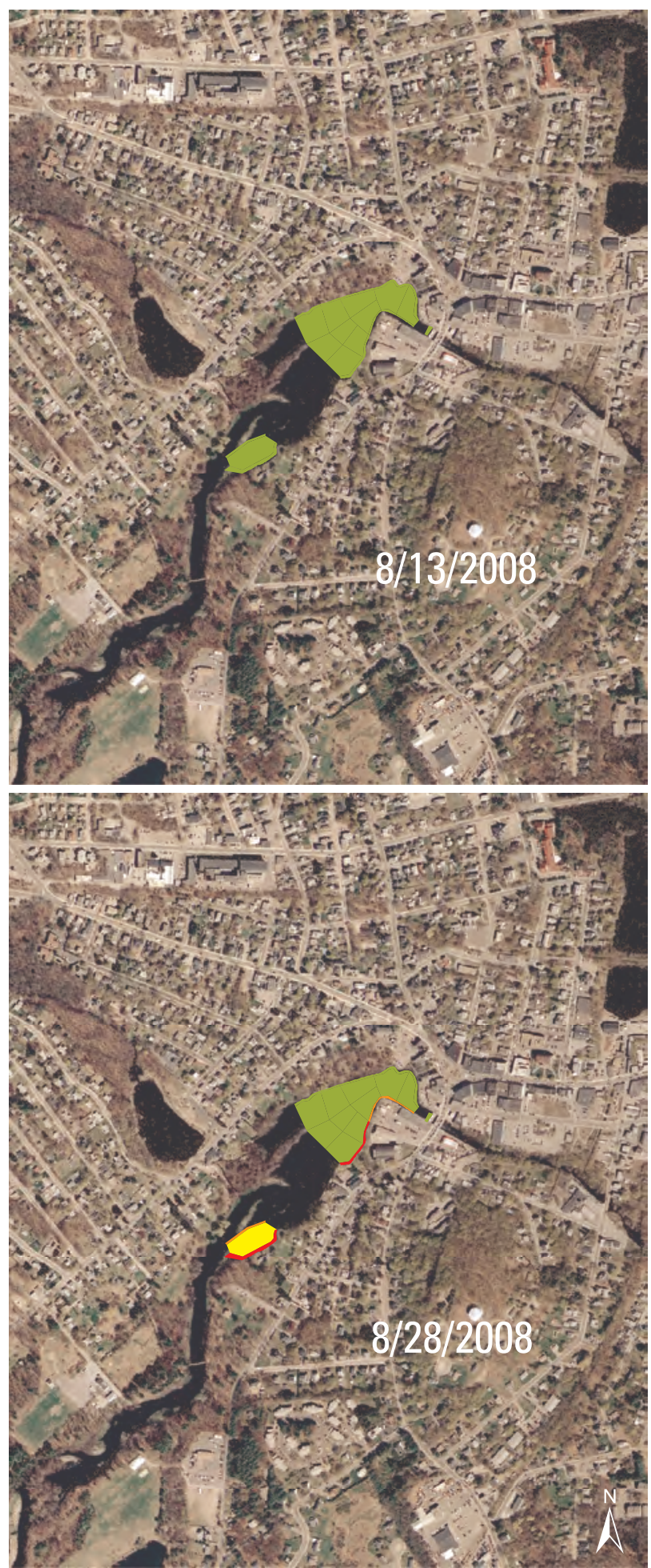

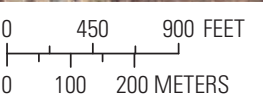

Figure 6.-Continued. 
D
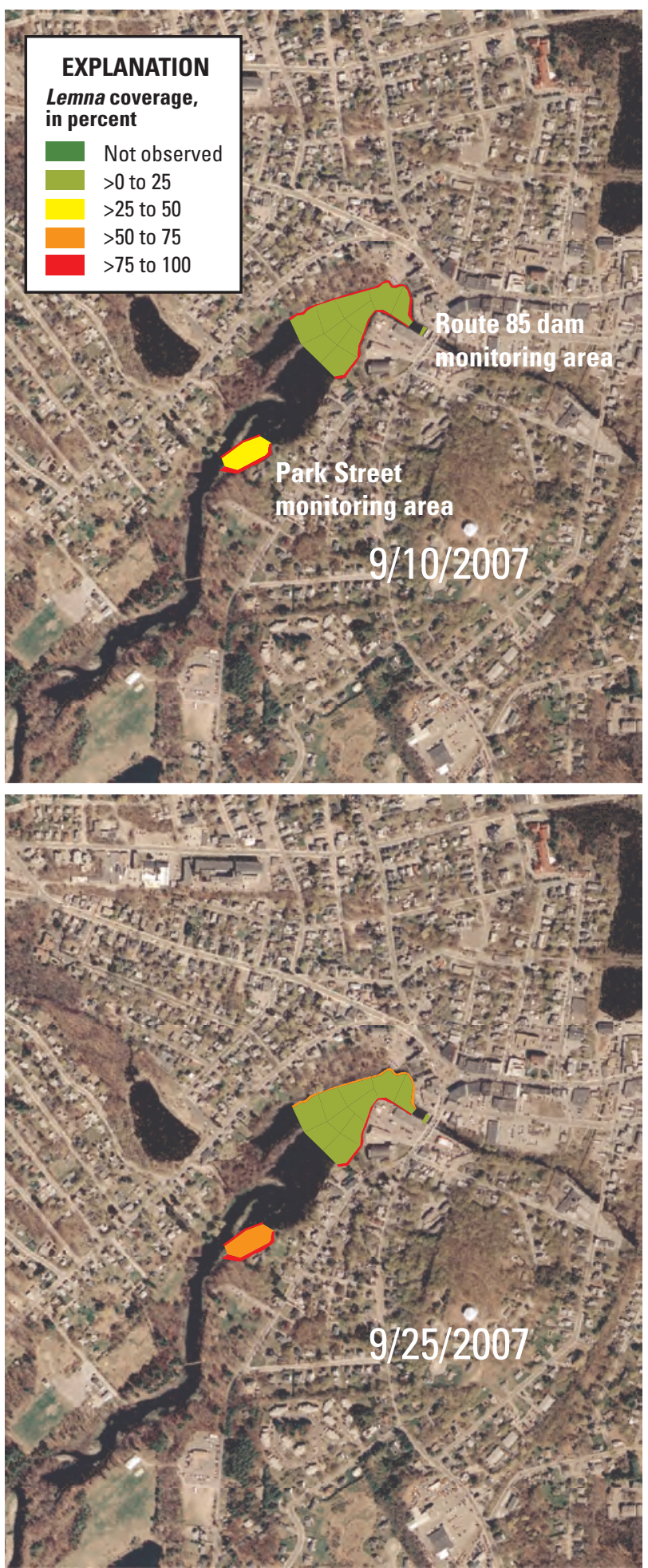

2008
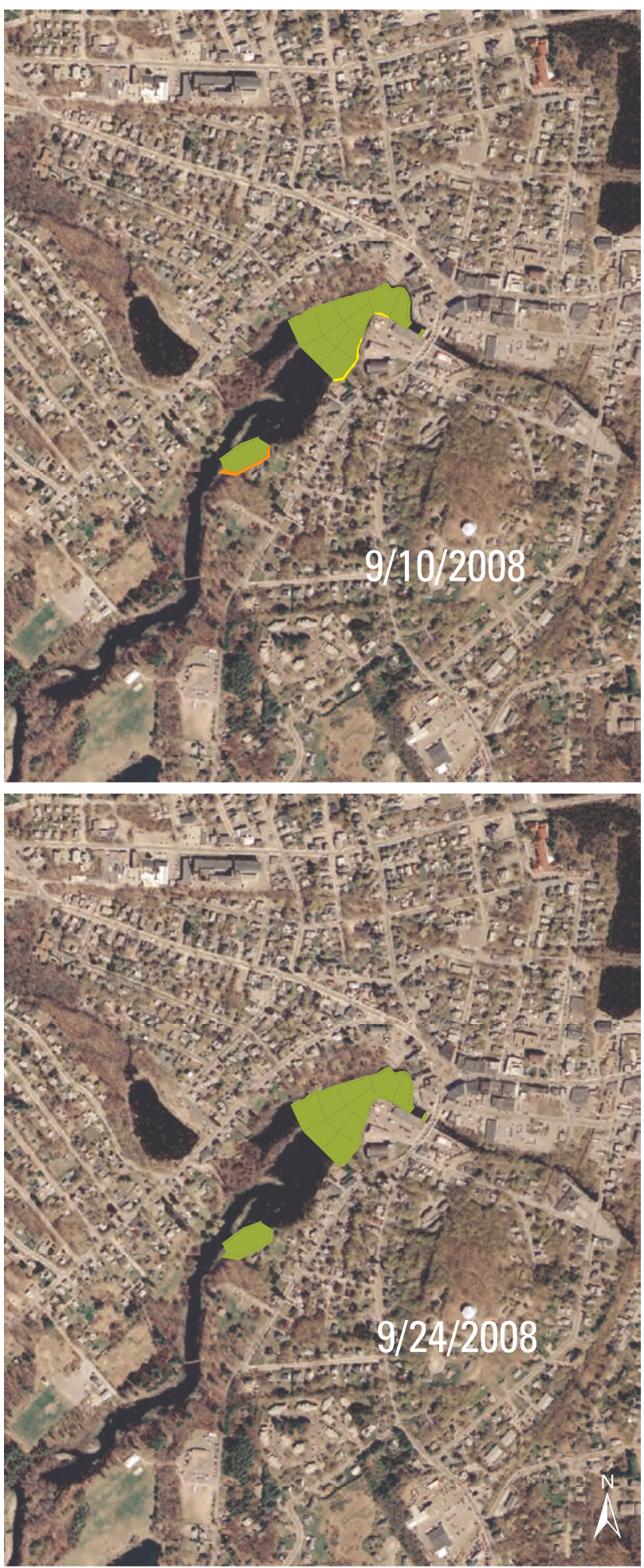

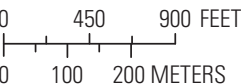

Figure 6.-Continued. 
$\boldsymbol{A}$
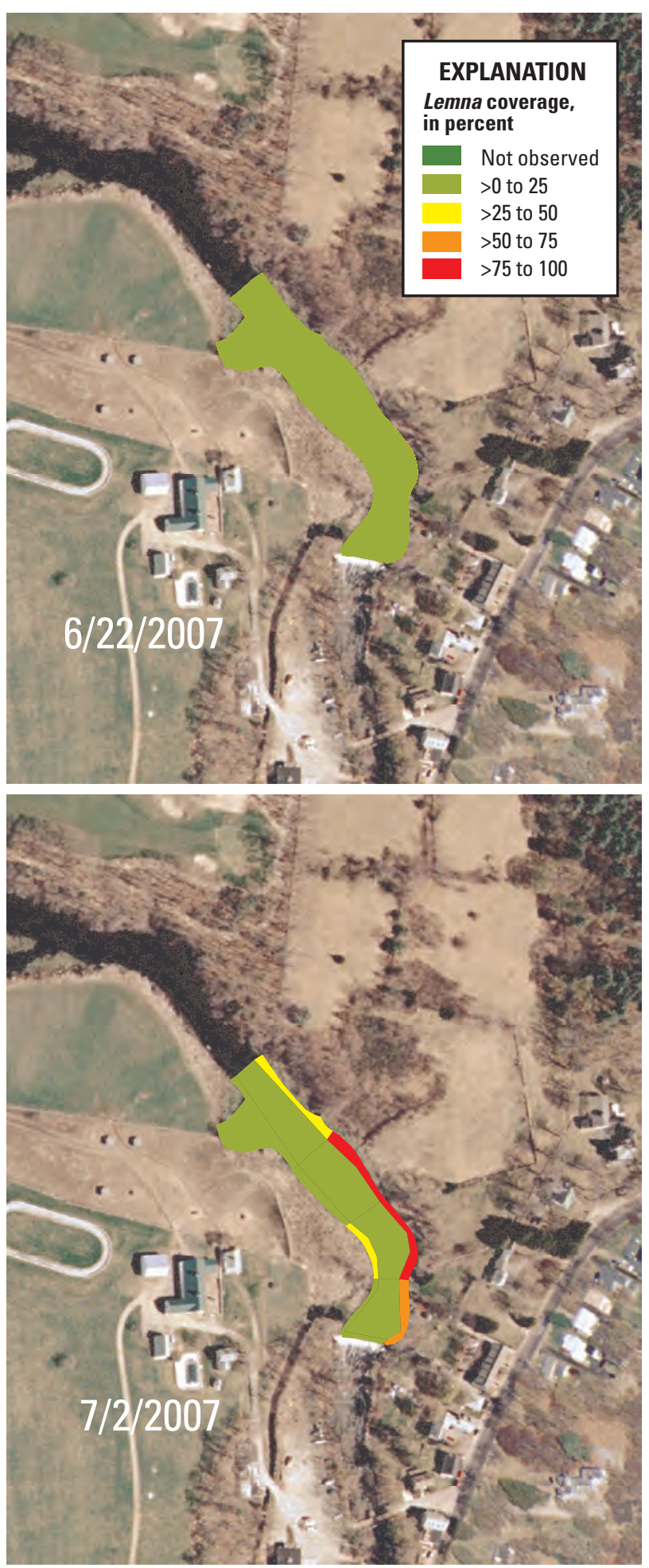

Base orthophoto from MassGIS, Commonwealth of Massachusetts, Information Technology Division

\section{8}
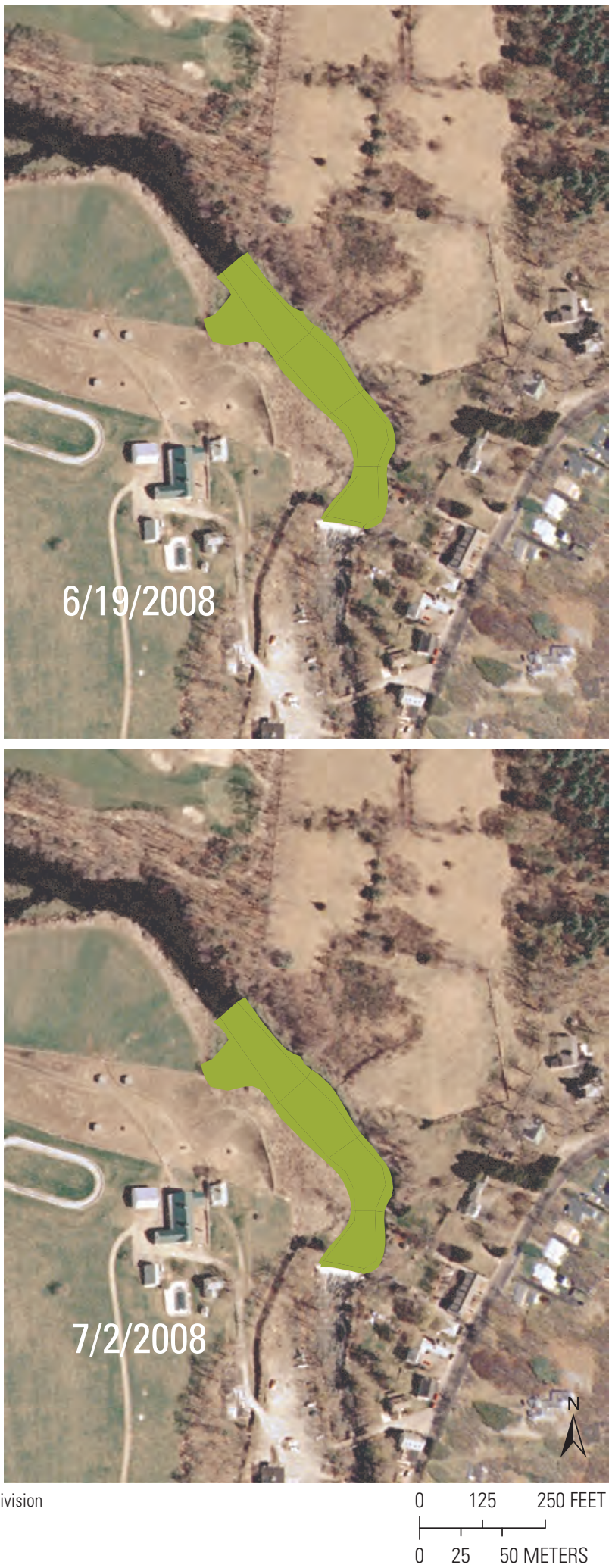

Figure 7. Percent coverages of Lemna in the Gleasondale impoundment based on visual observations on comparable dates in 2007 and 2008. >, greater than. 
B

2007
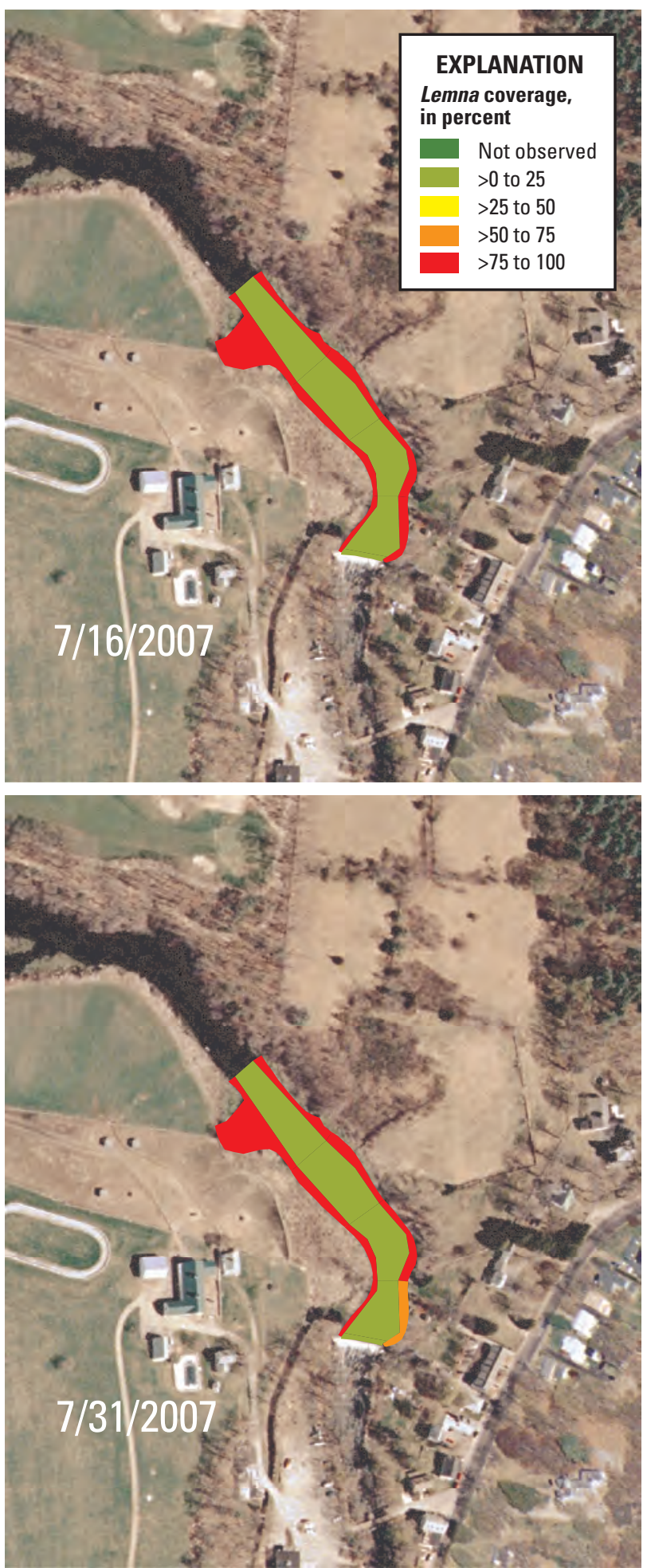

Base orthophoto from MassGIS, Commonwealth of Massachusetts, Information Technology Division

\section{8}
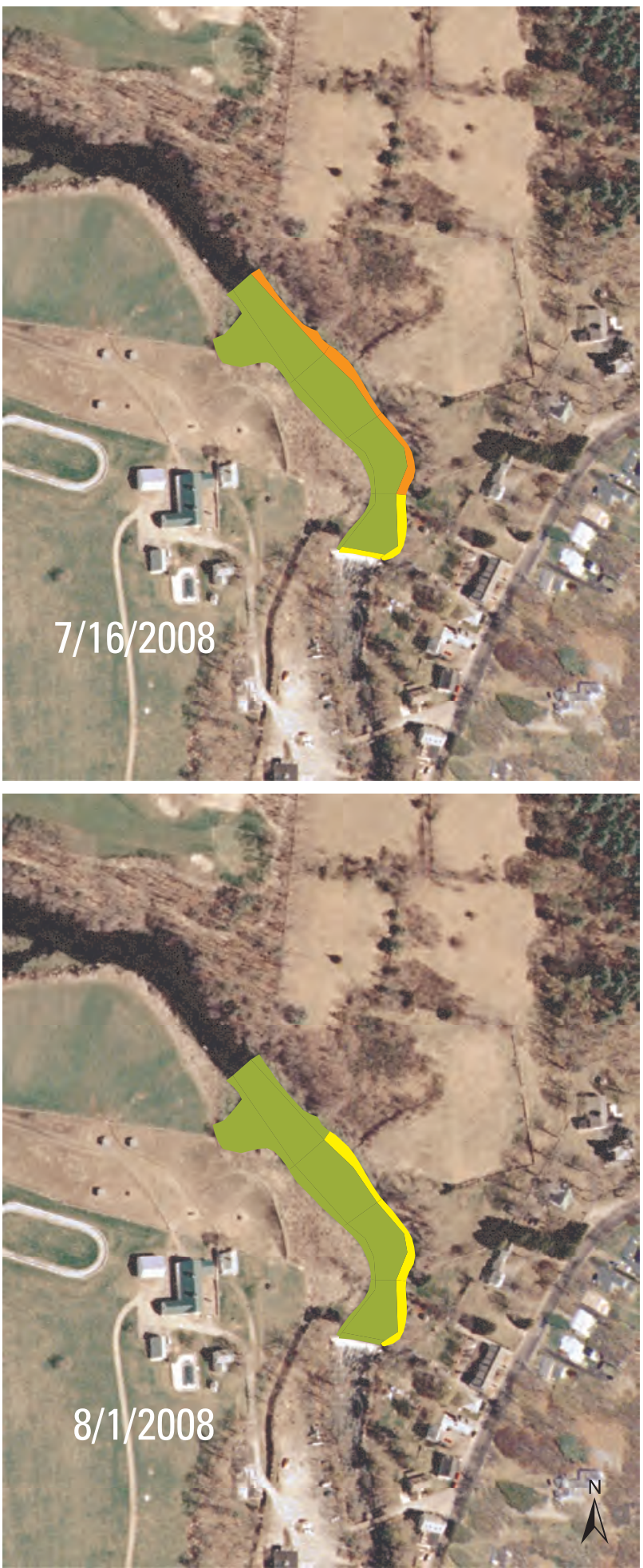

$0 \quad 125 \quad 250$ FEE

\begin{tabular}{lll}
1 & \multicolumn{1}{l}{${ }_{1}$} \\
0 & 25 & 50 METERS
\end{tabular}

Figure 7.-Continued. 
C
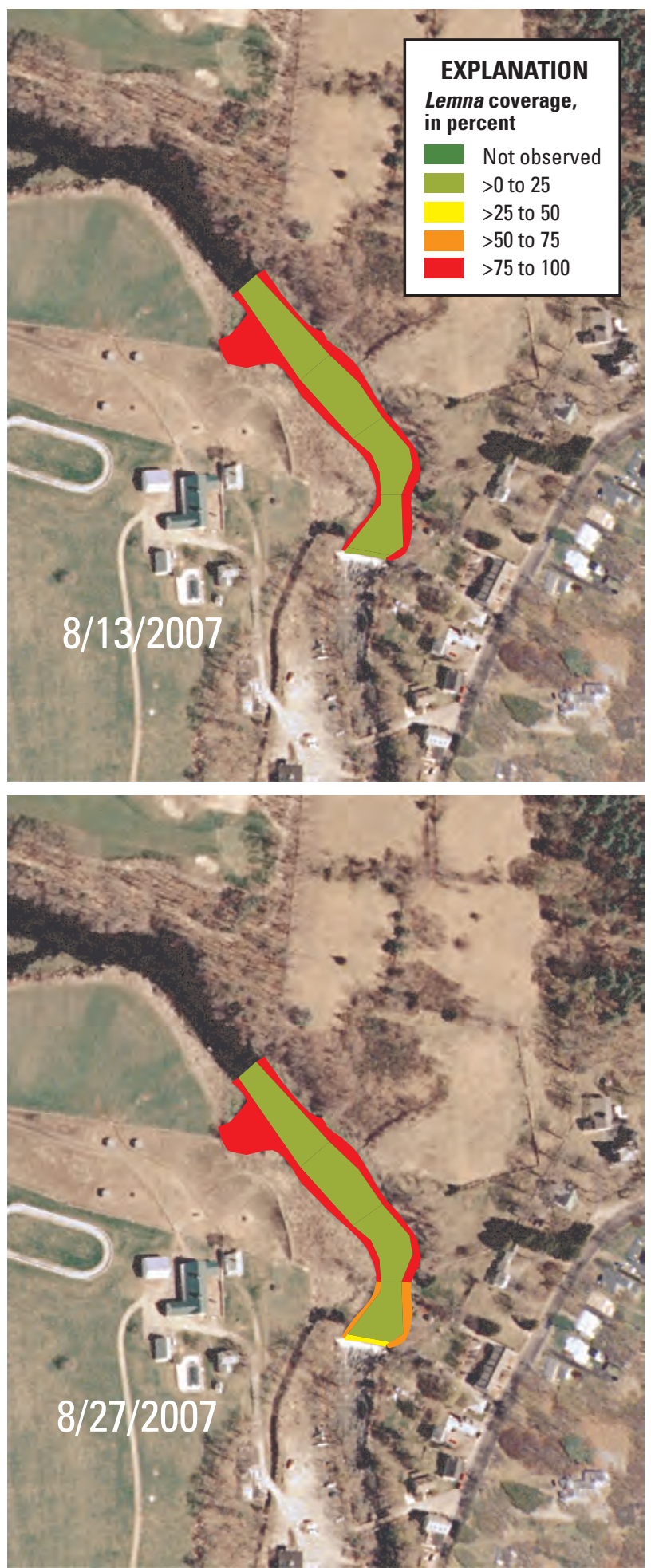

Base orthophoto from MassGIS, Commonwealth of Massachusetts, Information Technology Division

\section{8}
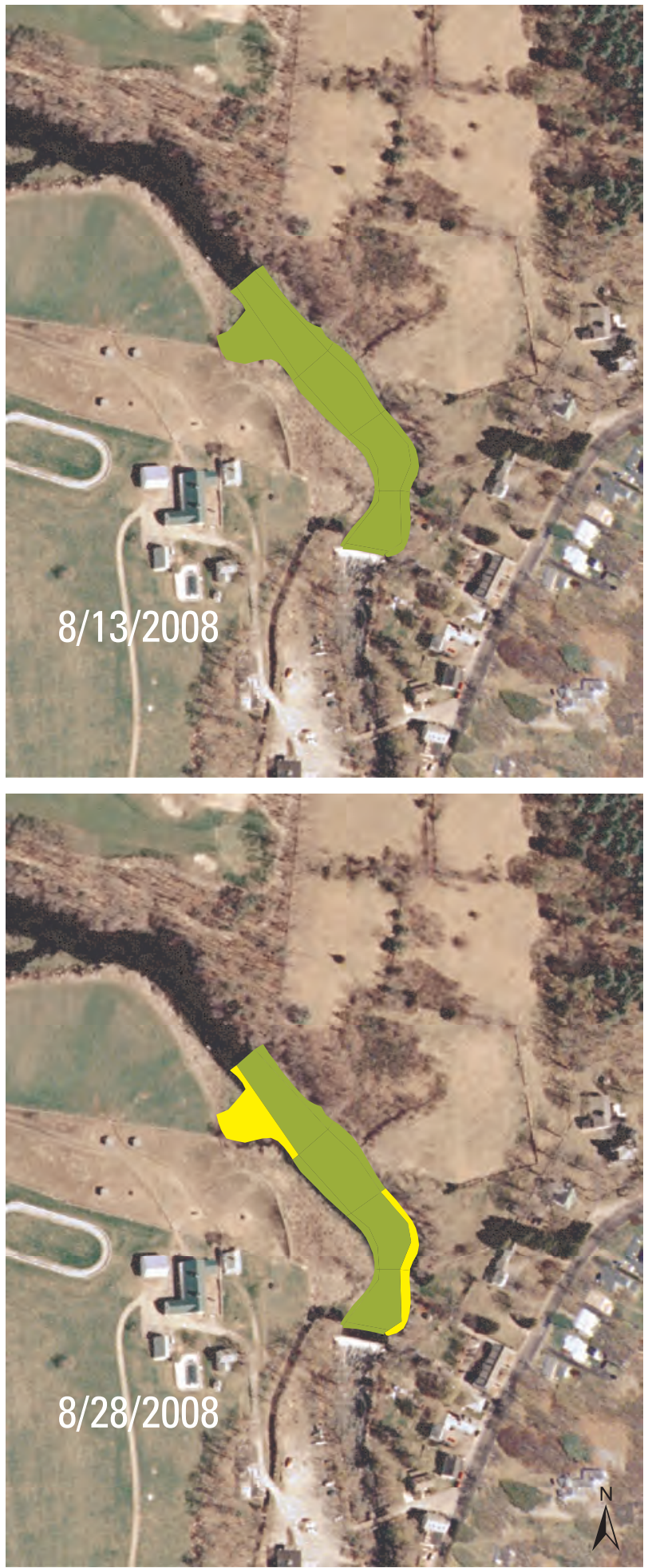

125

\begin{tabular}{llll}
\hline & 1 & \\
0 & 25 & 50 METERS
\end{tabular}

Figure 7.-Continued. 
D

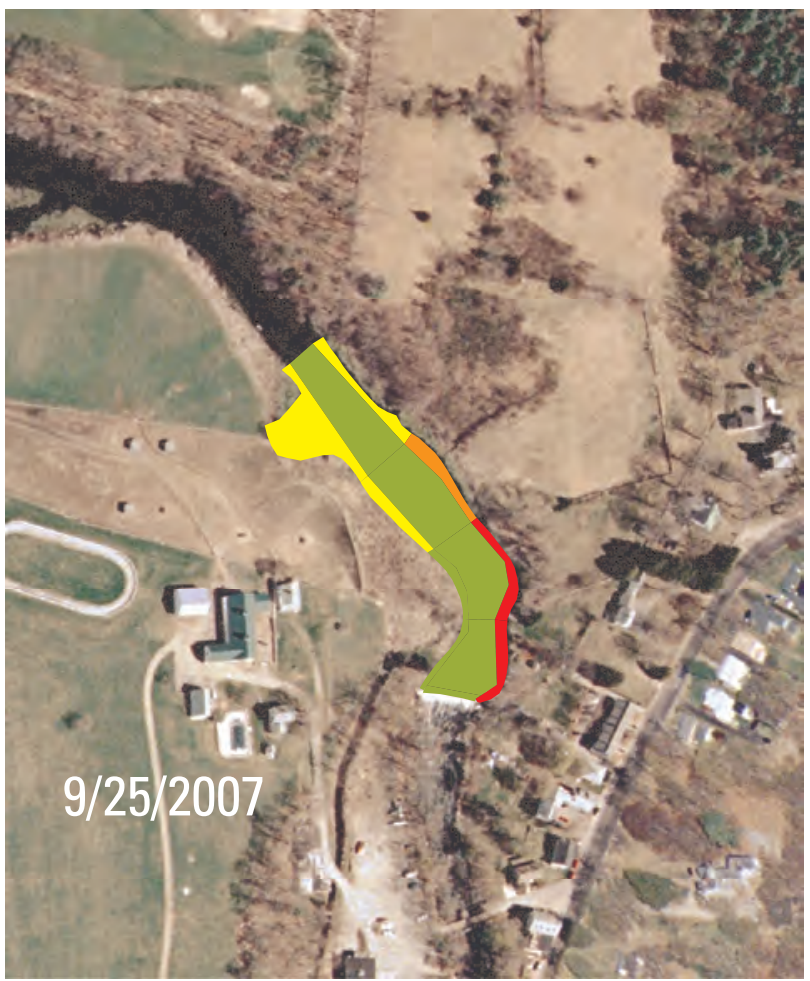

2007 Lemna coverage,

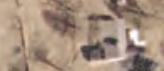
of -2 ses $x=$
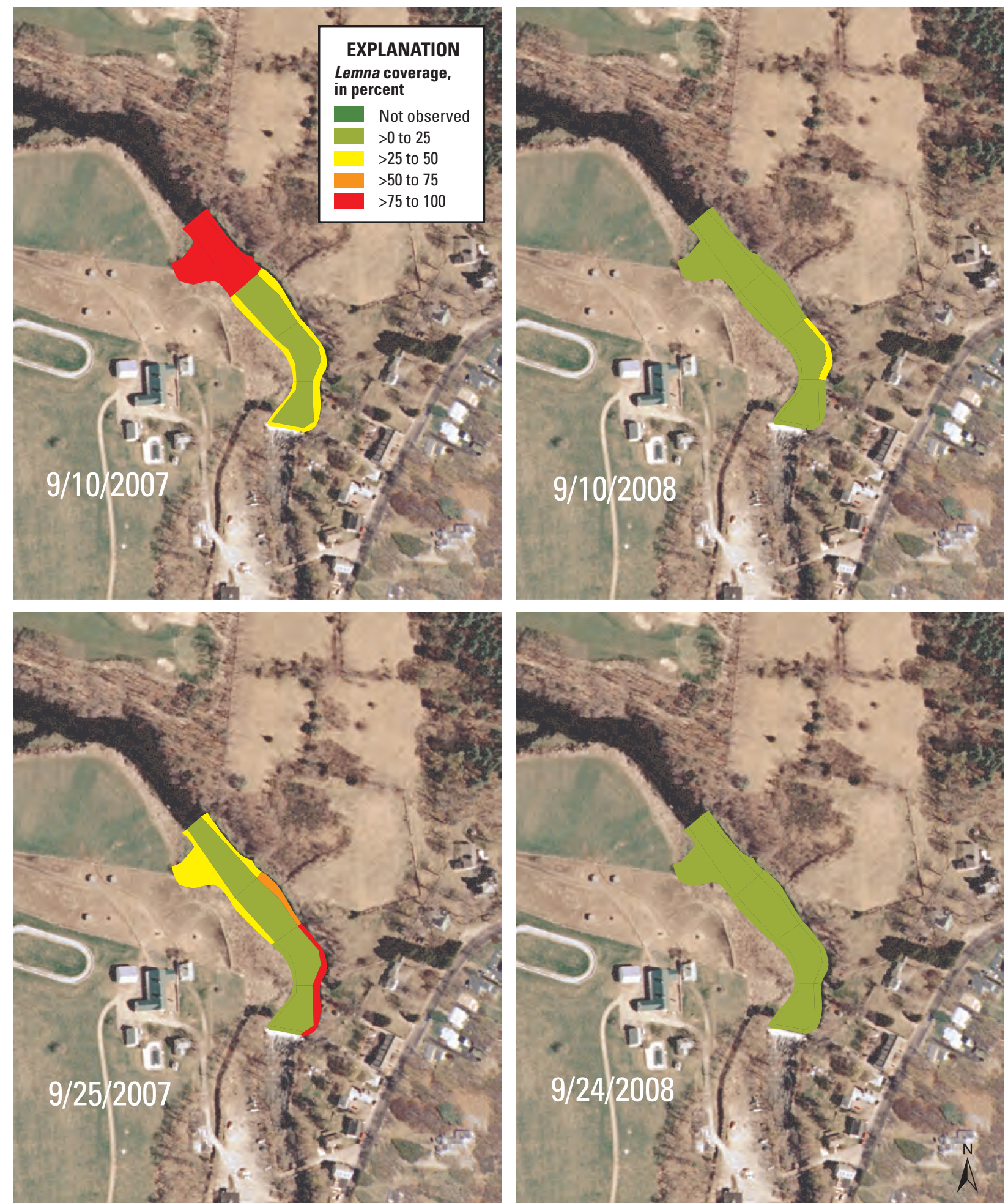

2008 
A
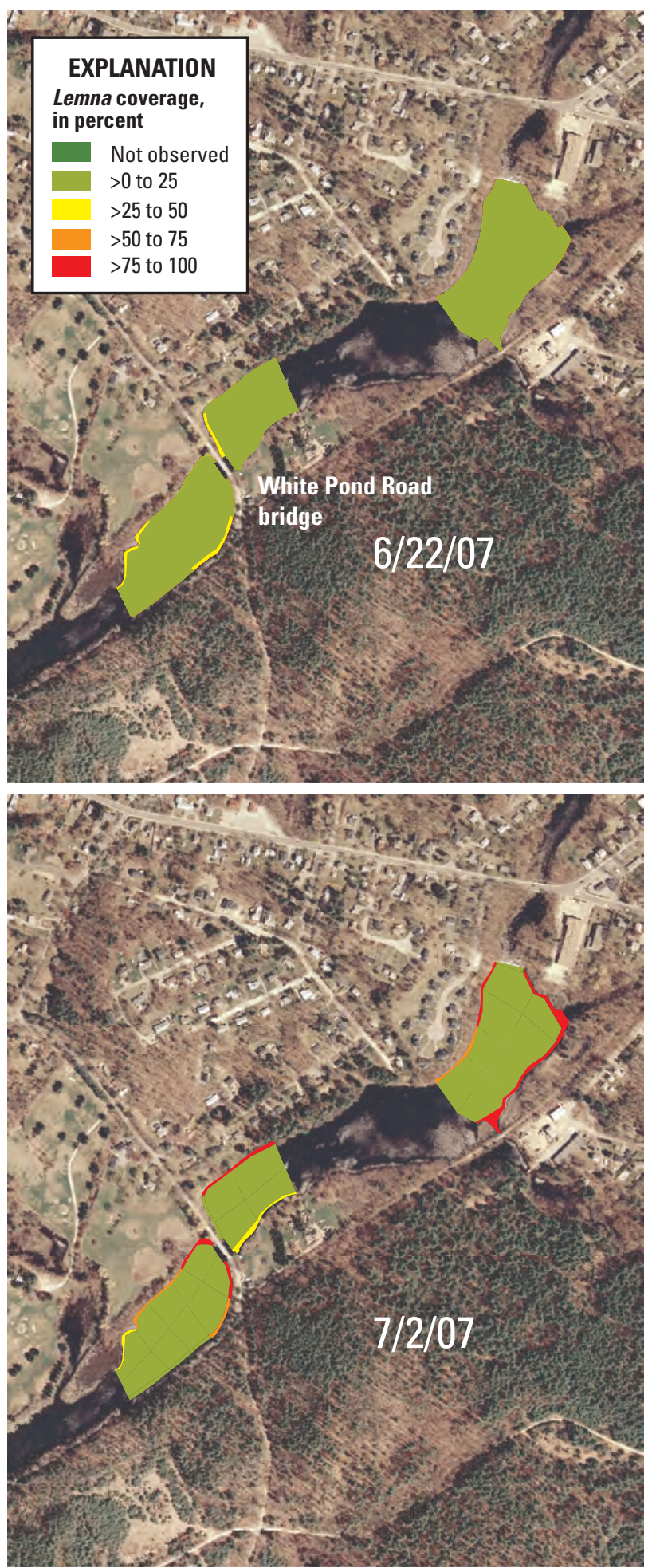

Base orthophoto from MassGIS, Commonwealth of Massachusetts, Information Technology Division
2008
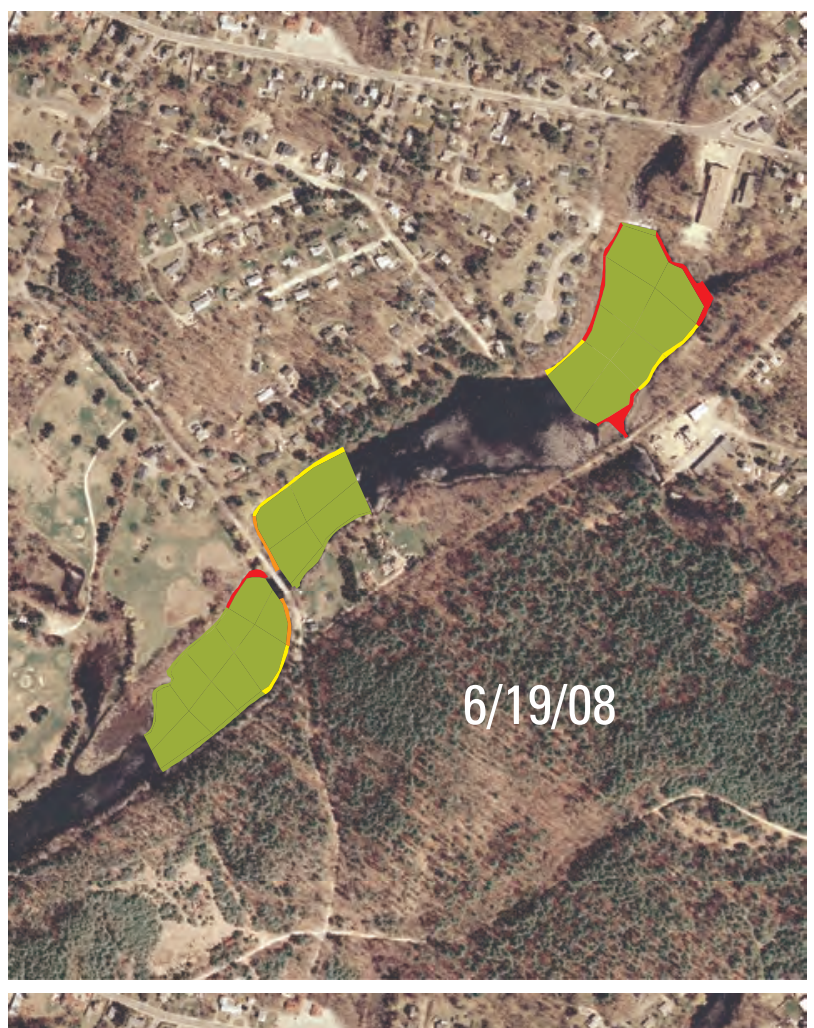
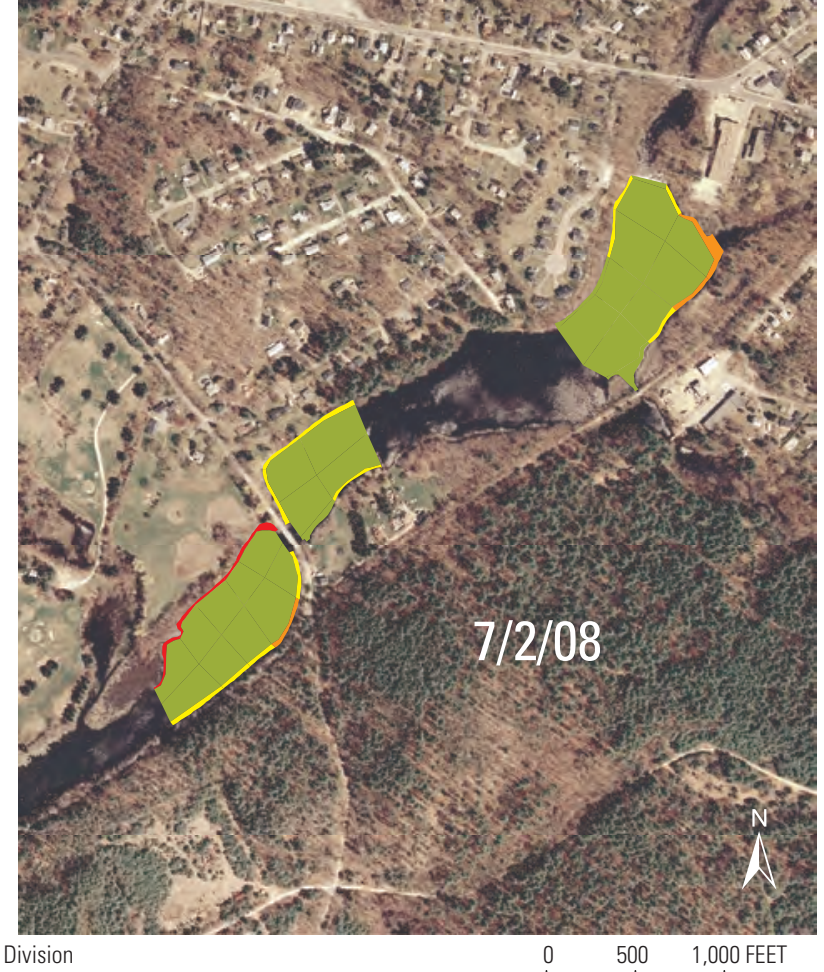

000 200 METERS

Figure 8. Percent coverages of Lemna in the Ben Smith impoundment upstream and downstream from White Pond Road and near the dam based on visual observations on comparable dates in 2007 and 2008. >, greater than. 
$\boldsymbol{B}$
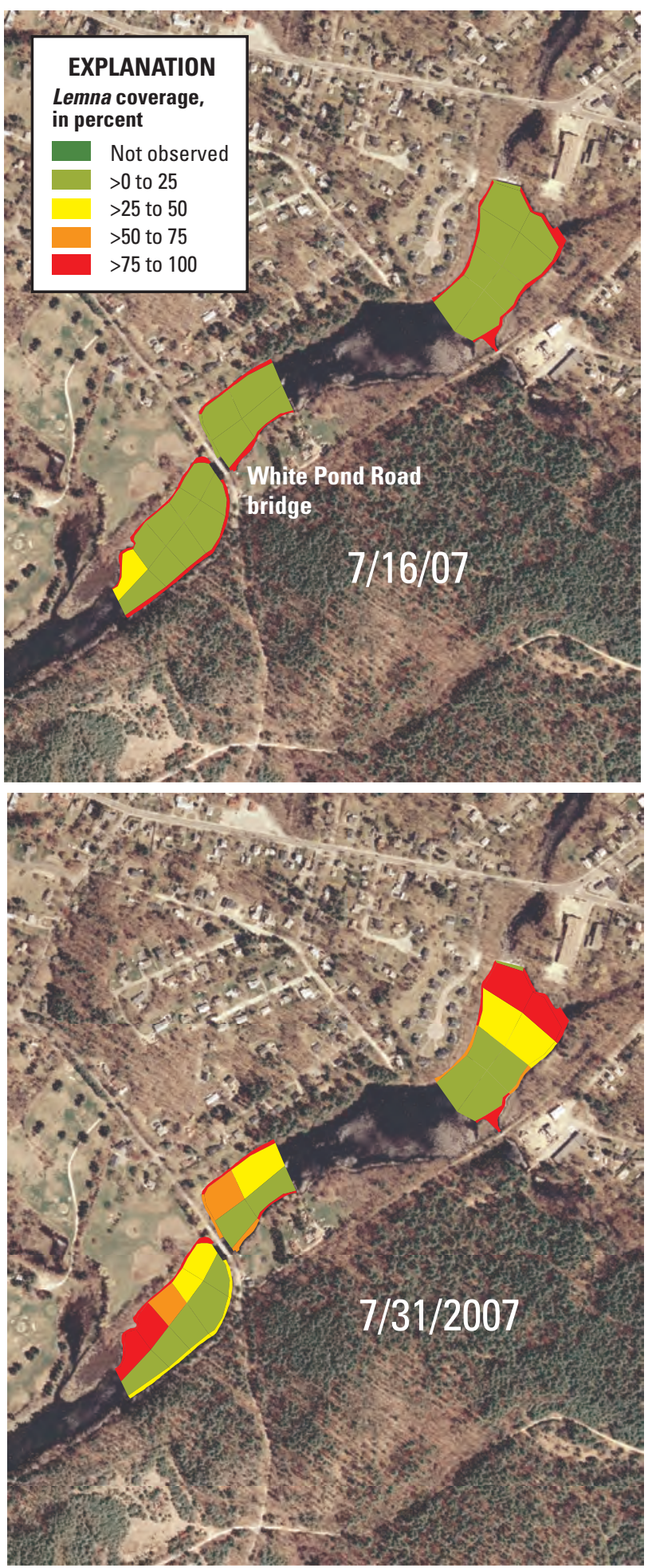

Base orthophoto from MassGIS, Commonwealth of Massachusetts, Information Technology Division
2008
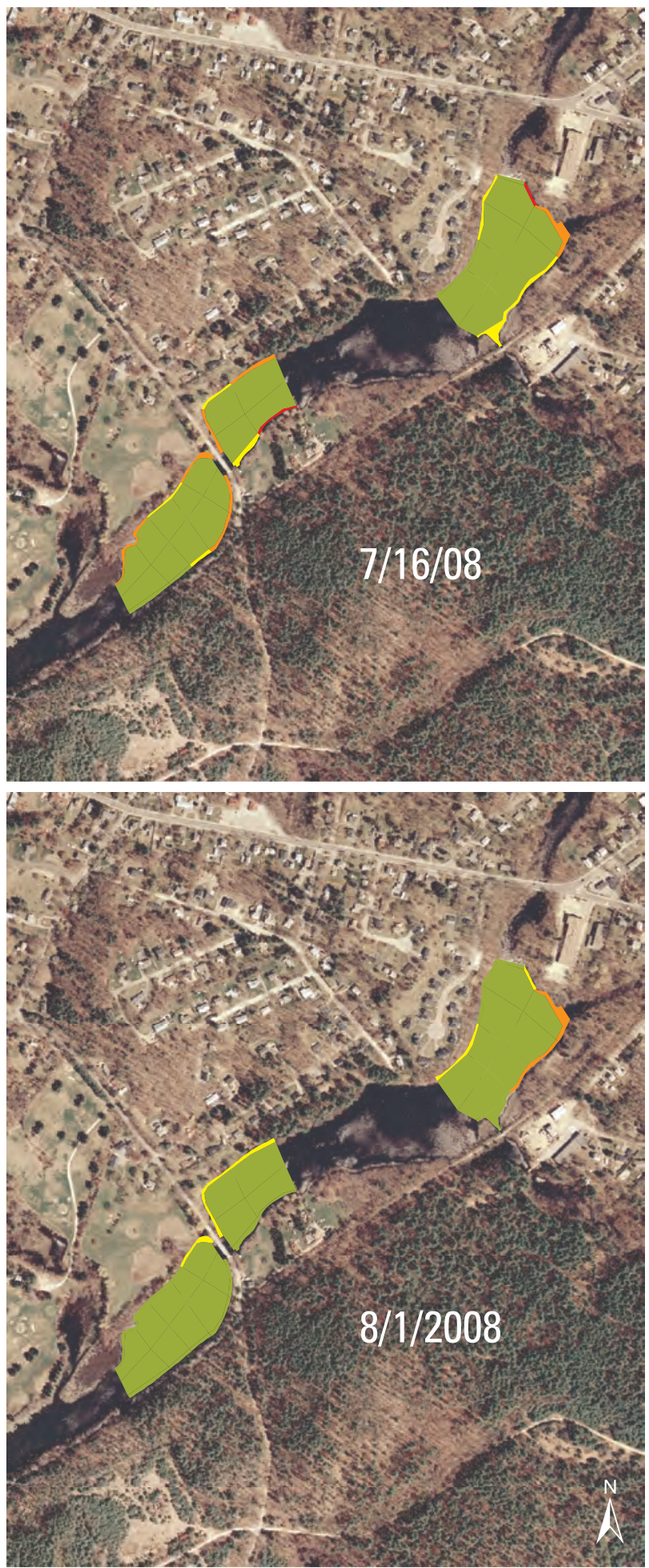

$0 \quad 500 \quad 1,000$ FEET

$0 \quad 100 \quad 200$ METERS

Figure 8.-Continued. 
C
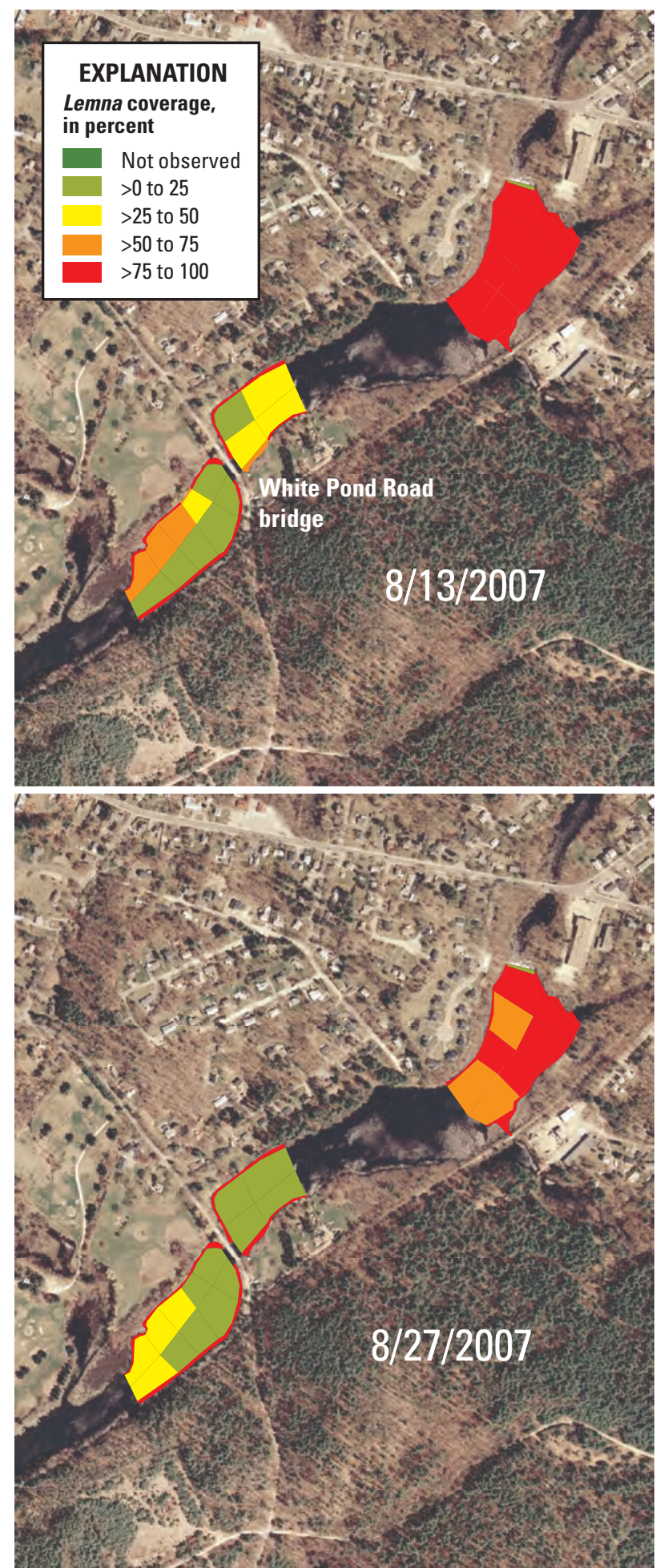

Base orthophoto from MassGIS, Commonwealth of Massachusetts, Information Technology Division

\section{8}
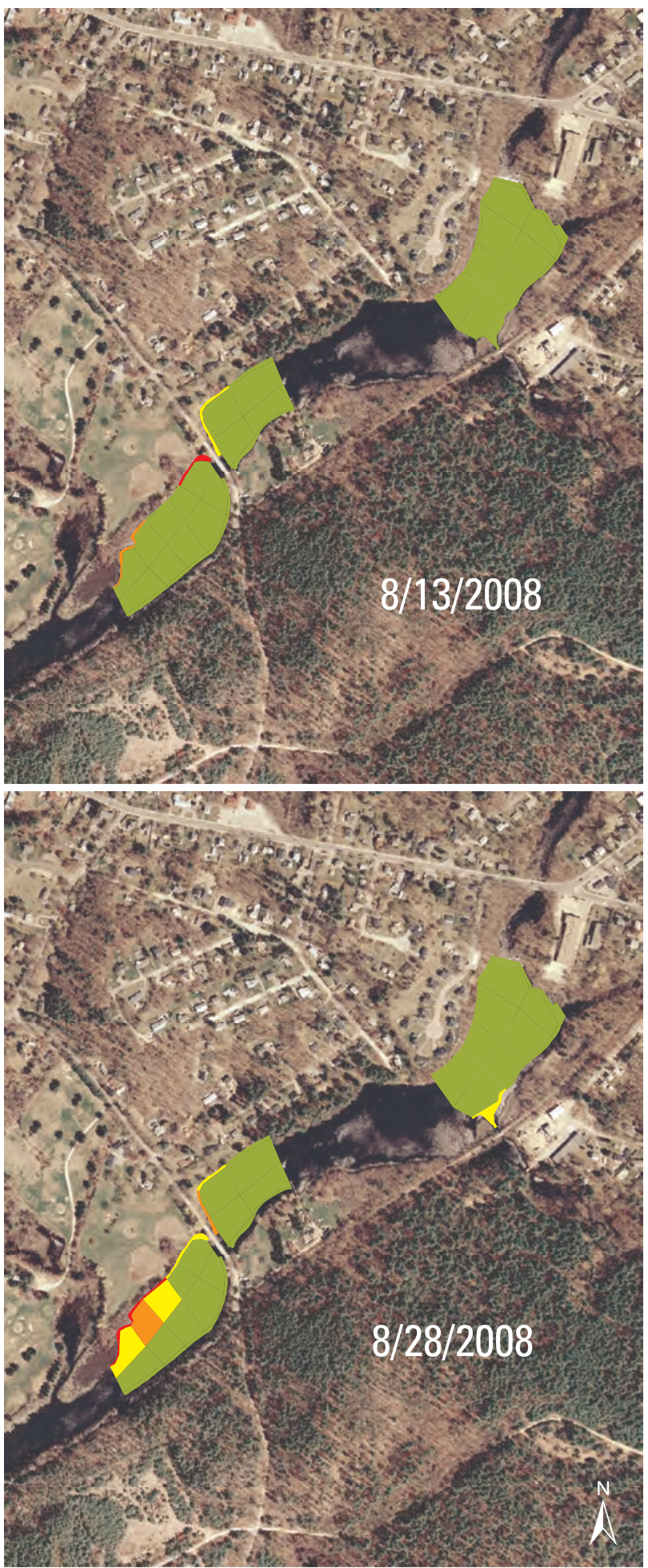

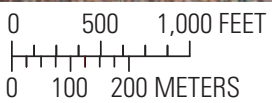

Figure 8.-Continued. 
D
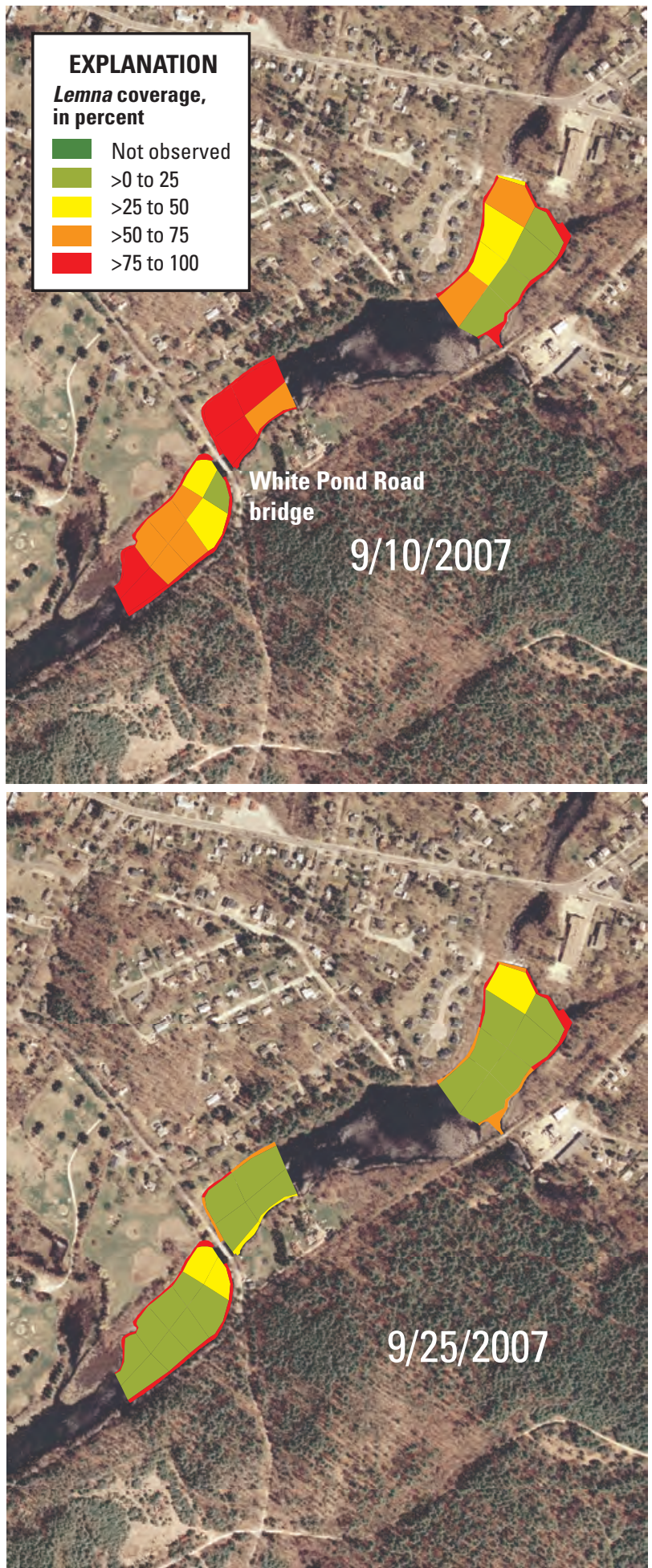

Base orthophoto from MassGIS, Commonwealth of Massachusetts, Information Technology Division

\section{8}
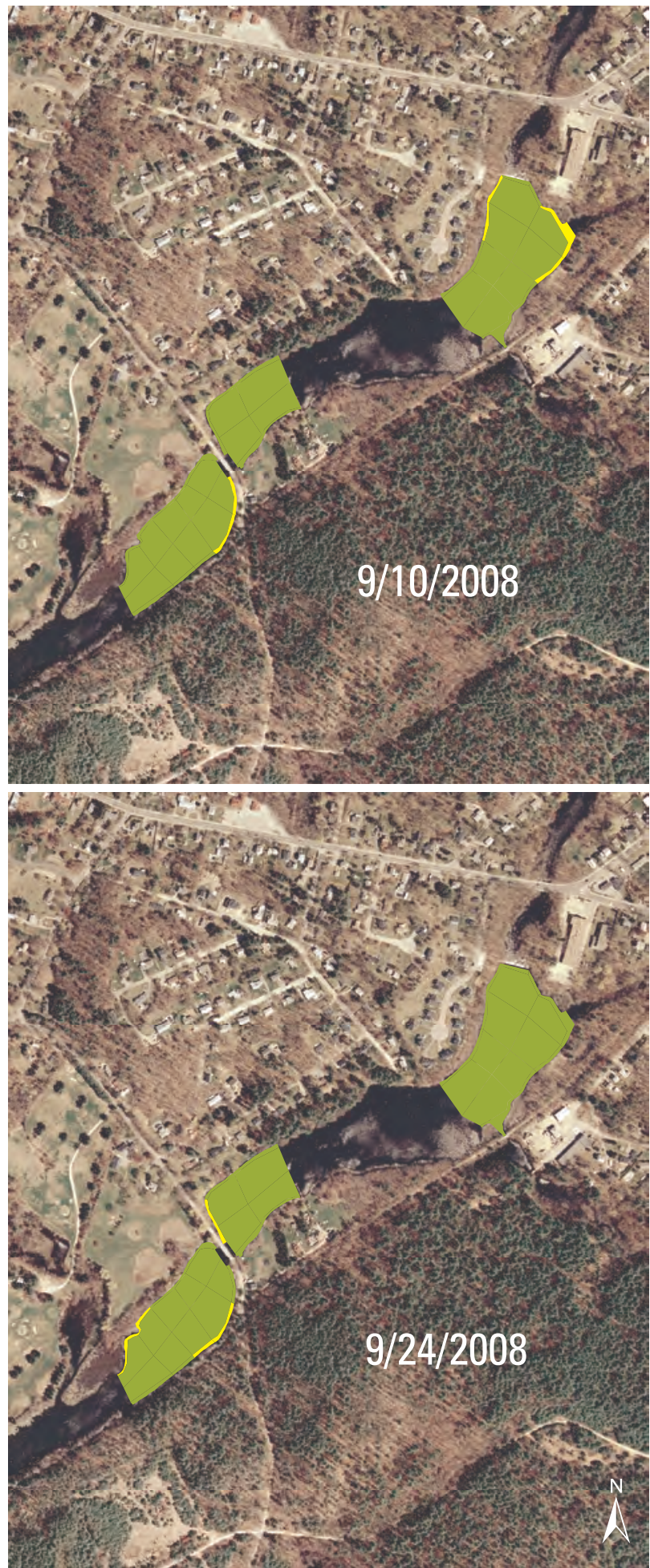

$\begin{array}{lll}0 & 500 \quad 1,000 \text { FEET }\end{array}$

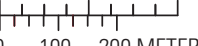

Figure 8.-Continued. 
$\boldsymbol{A}$
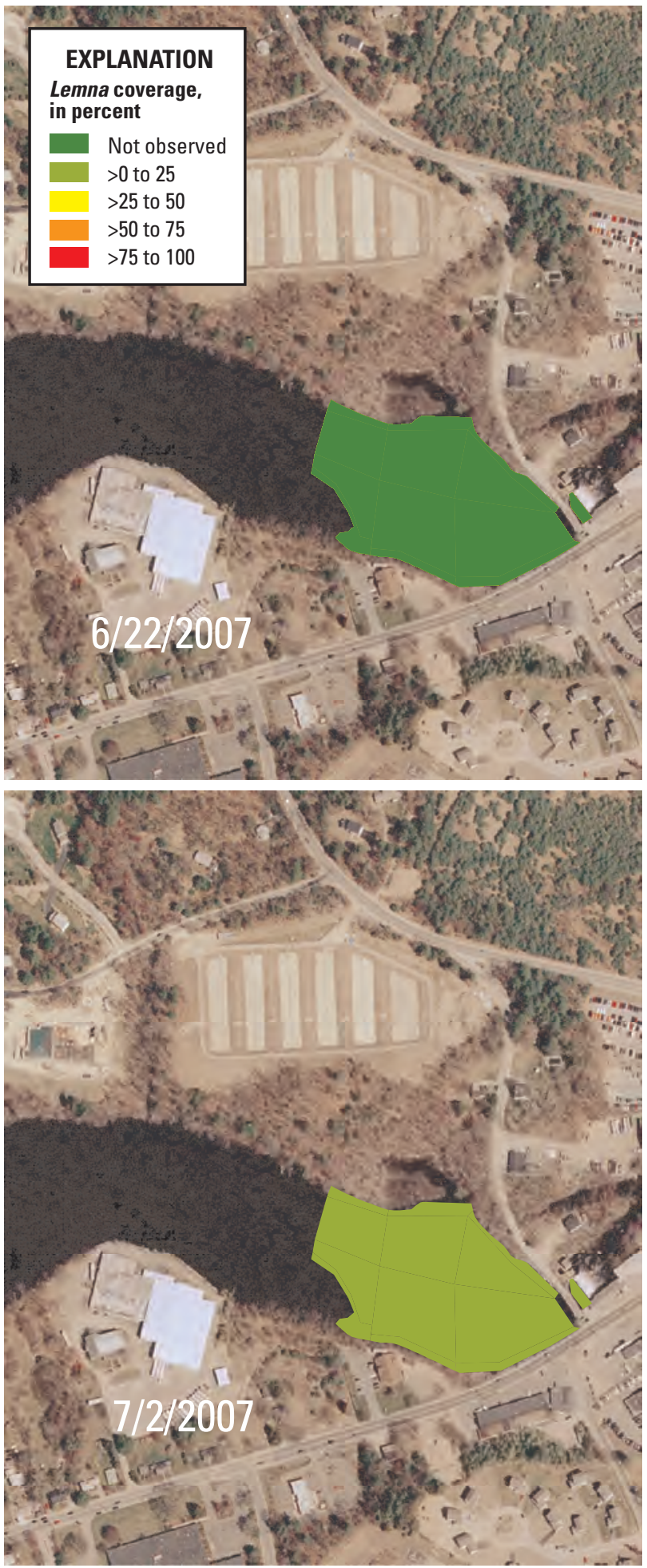

Base orthophoto from MassGIS, Commonwealth of Massachusetts, Information Technology Division

\section{8}
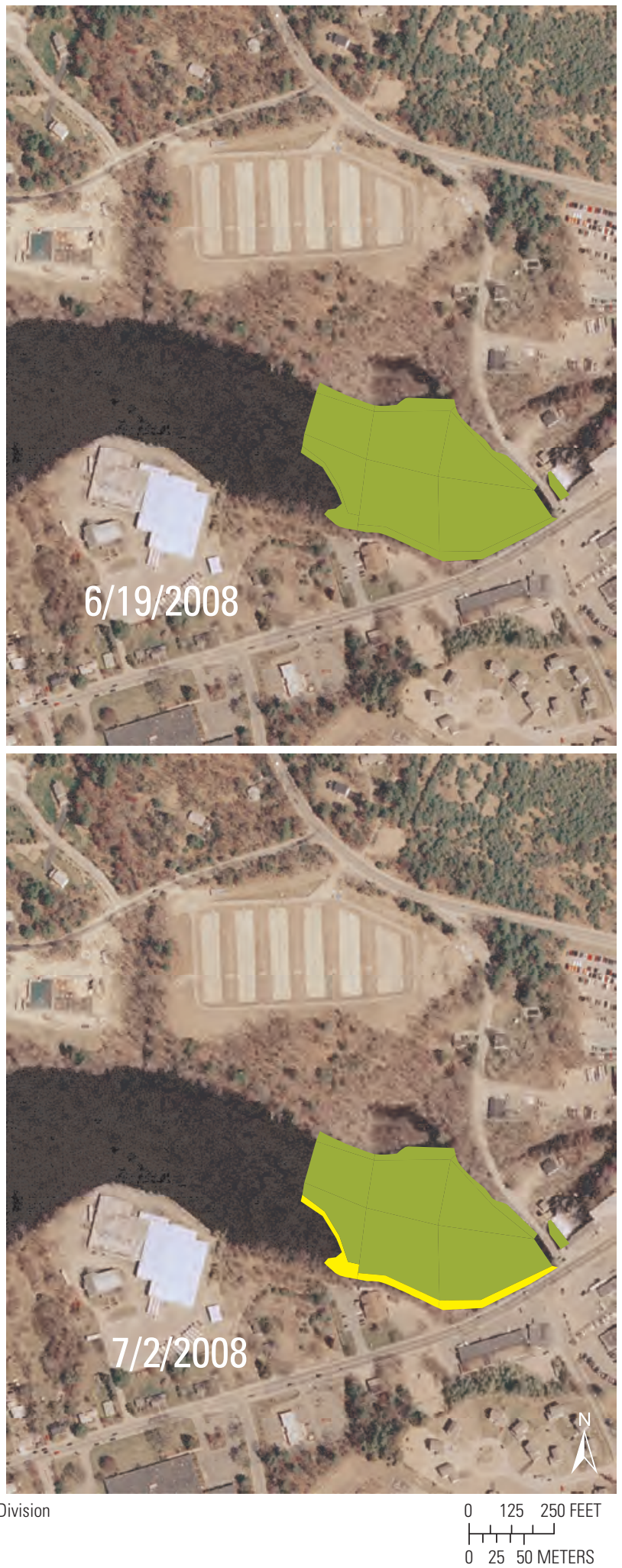

Figure 9. Percent coverages of Lemna in the Powdermill impoundment based on visual observations on comparable dates in 2007 and 2008. $>$, greater than. 
B
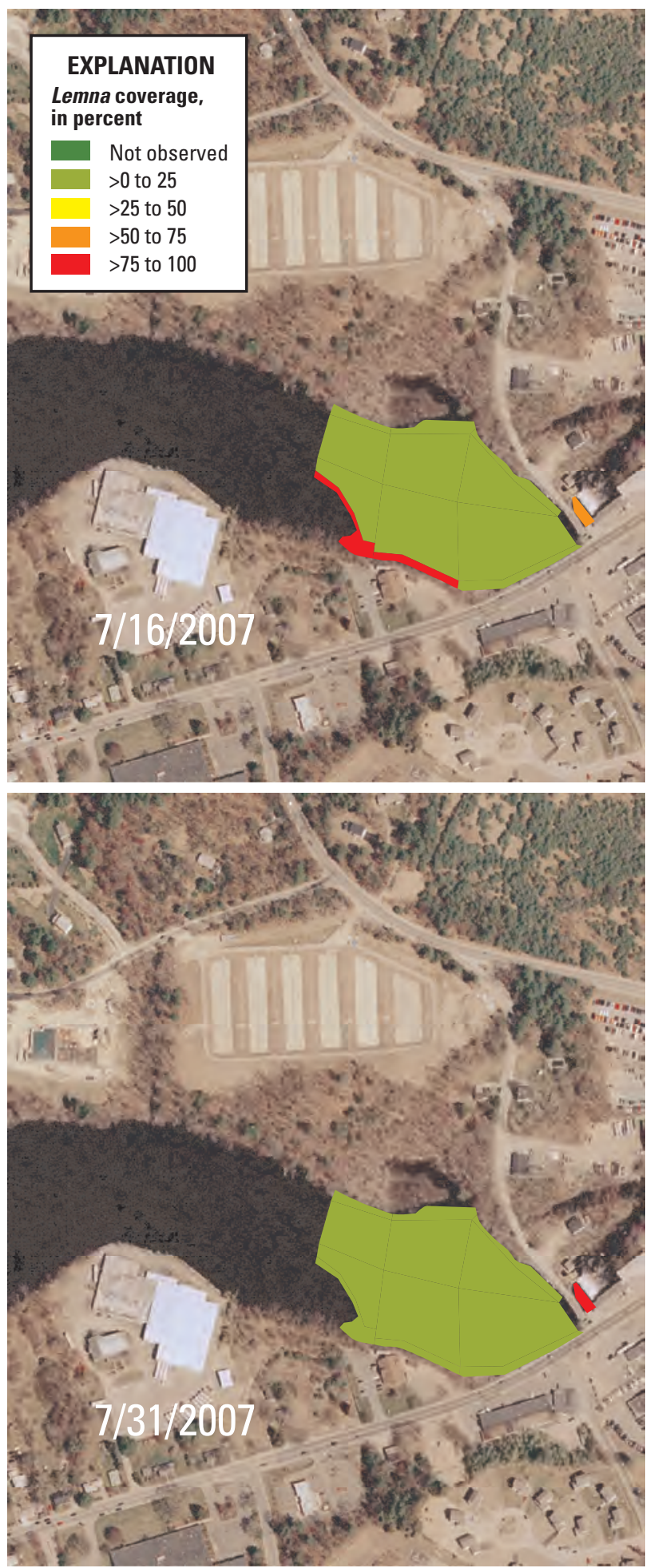

Base orthophoto from MassGIS, Commonwealth of Massachusetts, Information Technology Division

\section{8}
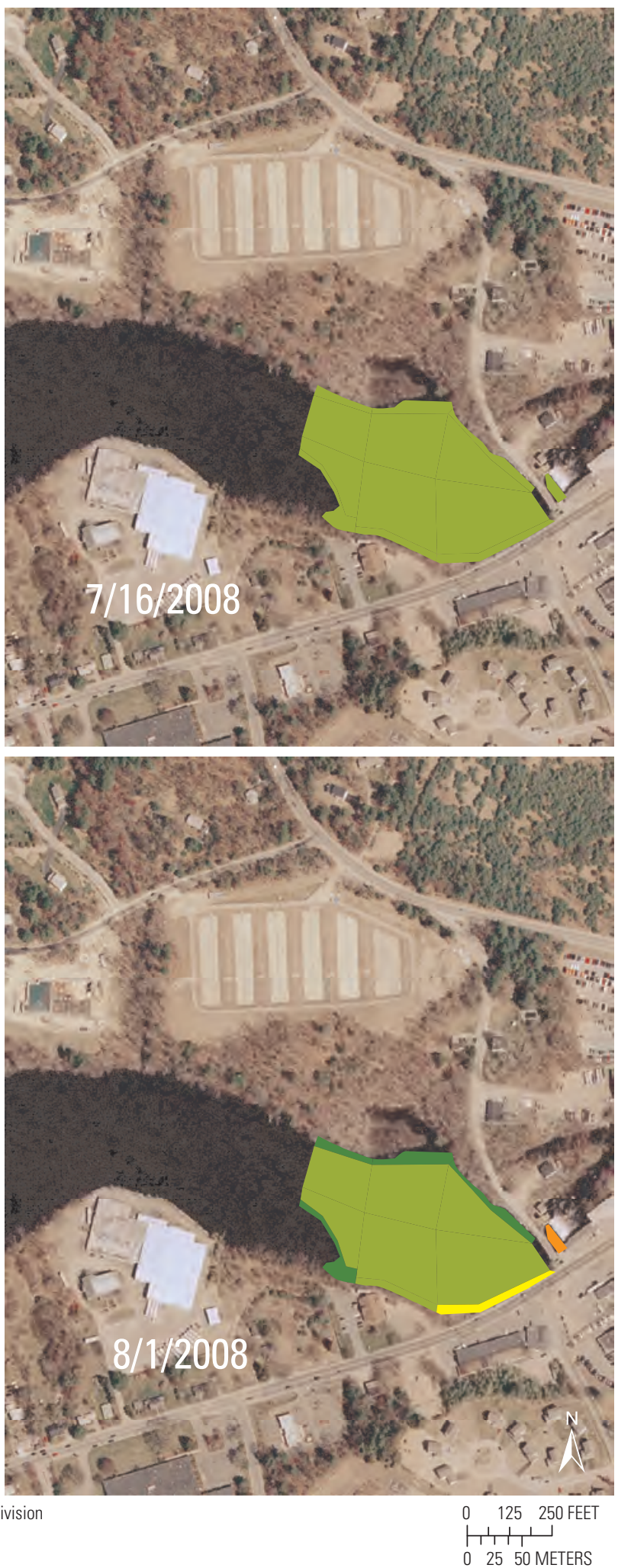

Figure 9.-Continued. 
C
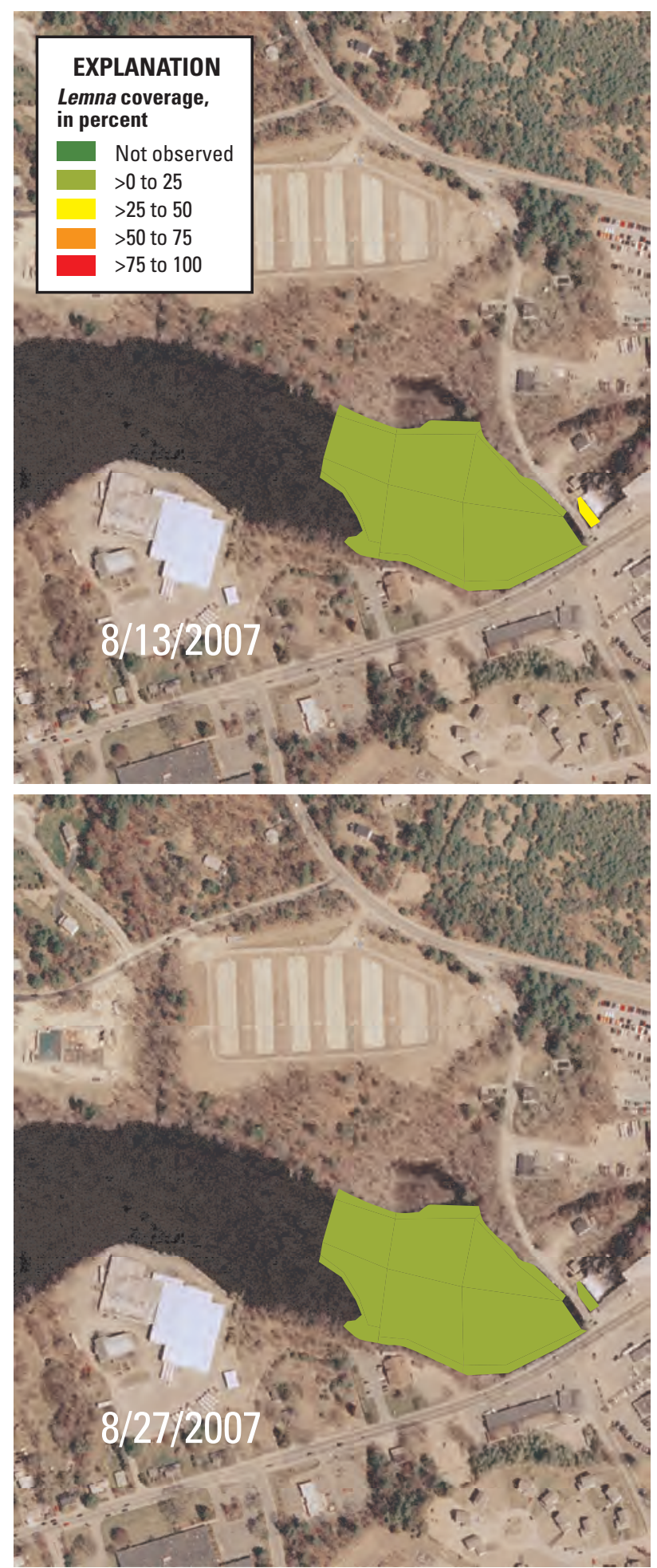

Base orthophoto from MassGIS, Commonwealth of Massachusetts, Information Technology Division

\section{8}
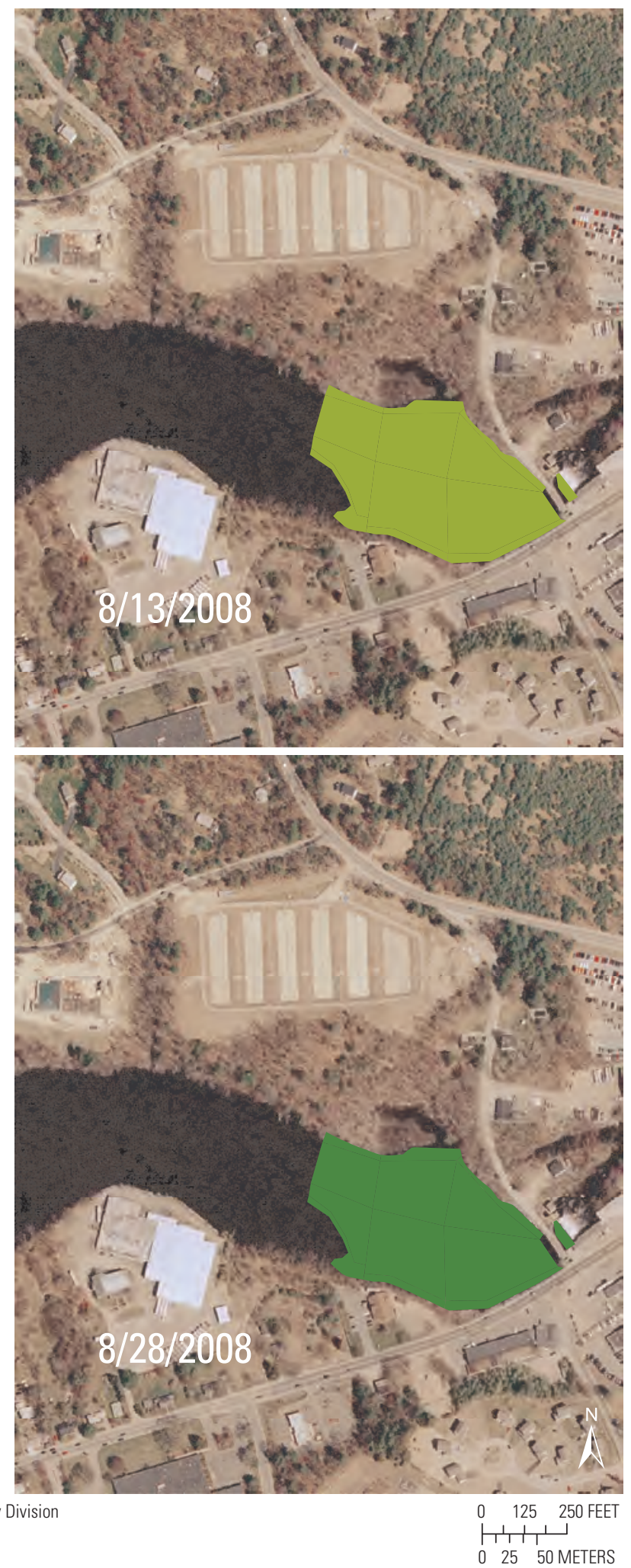

Figure 9.-Continued. 
D
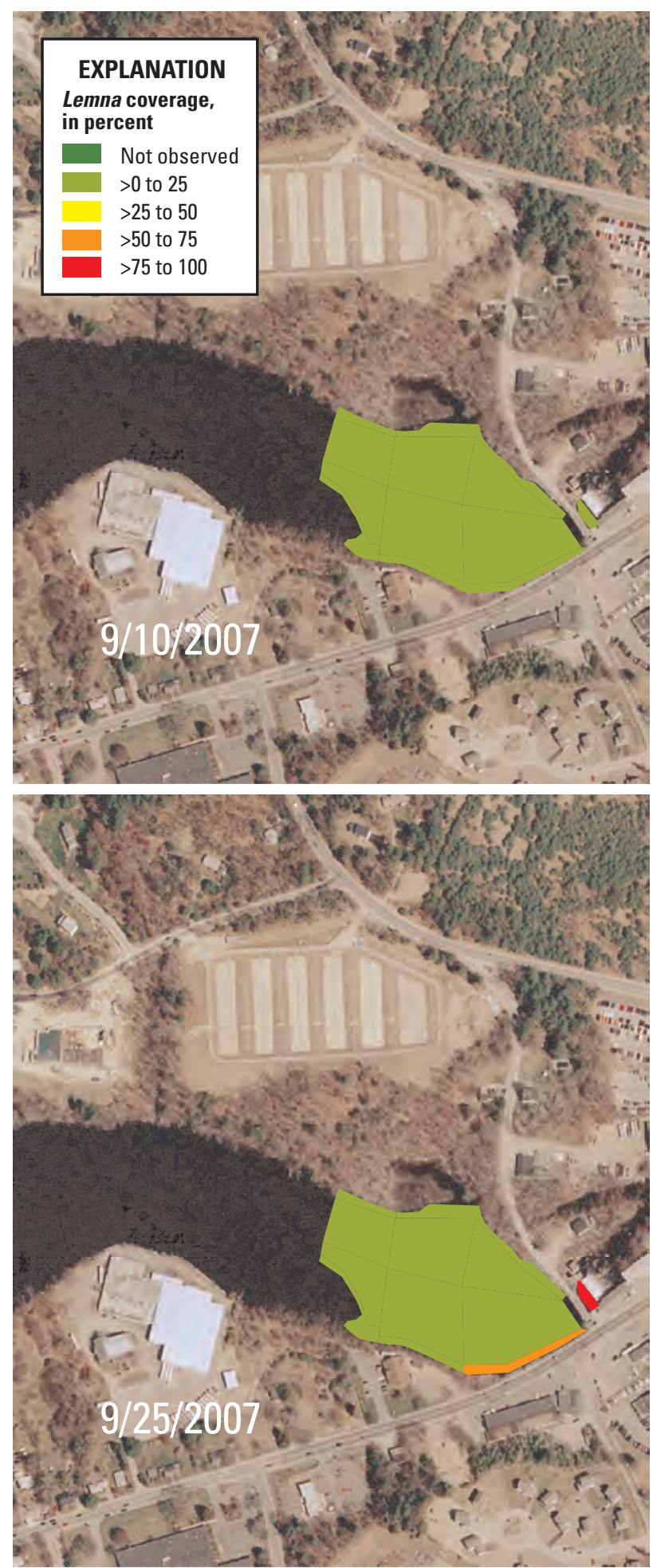

Base orthophoto from MassGIS, Commonwealth of Massachusetts, Information Technology Division
2008
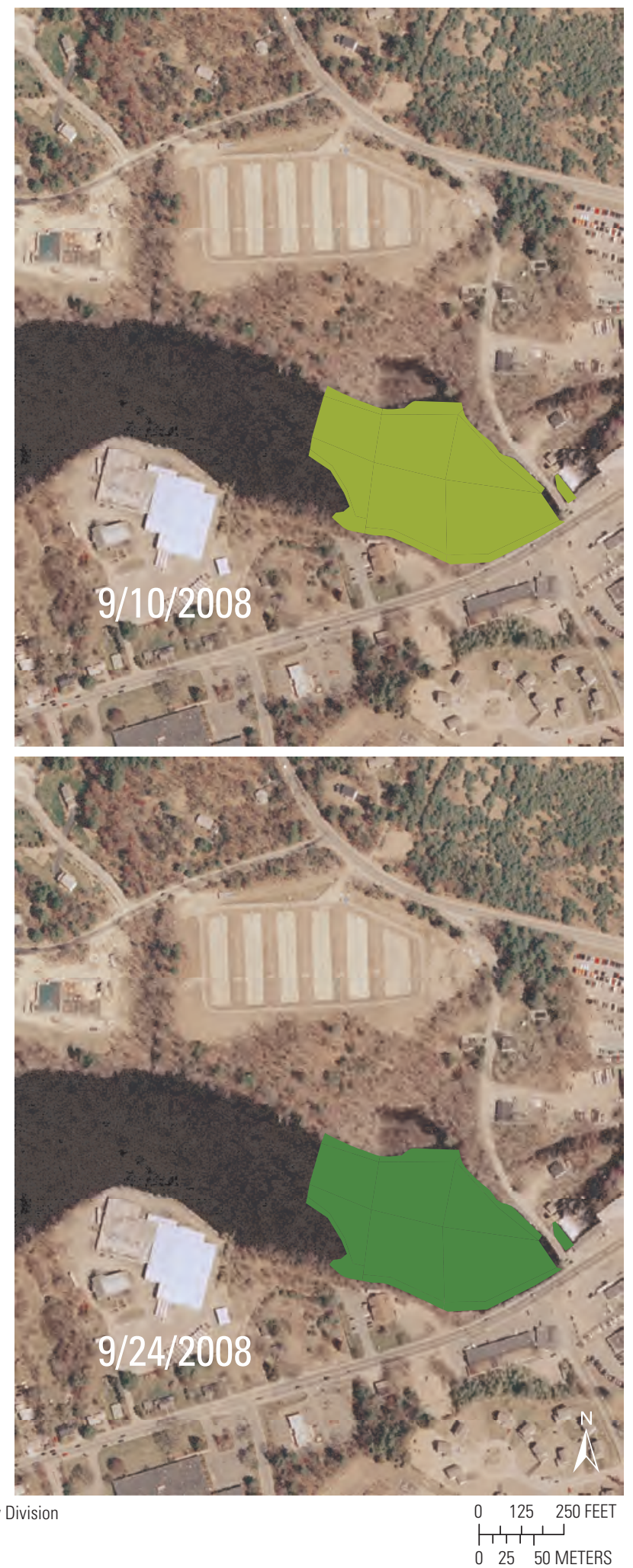

Figure 9.-Continued. 
THIS PAGE INTENTIONALLY LEFT BLANK 
Prepared by the Pembroke and Sacramento Publishing Service Centers.

For more information concerning this report, contact:

\section{Director}

U.S. Geological Survey

Massachusetts-Rhode Island Water Science Center

10 Bearfoot Road

Northborough, MA 01532

dc_ma@usgs.gov

or visit our Web site at:

http://ma.water.usgs.gov 


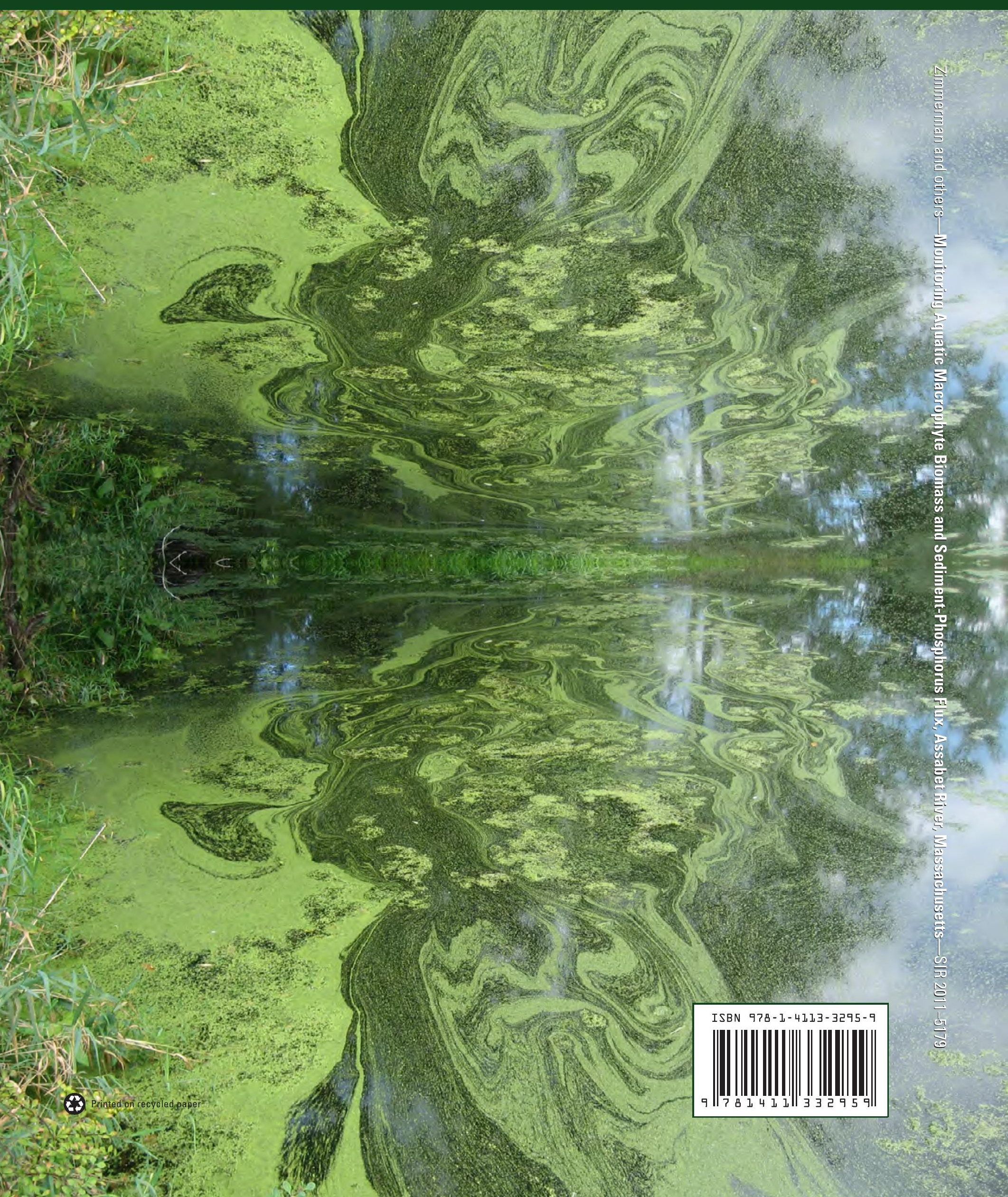

